Portland State University

PDXScholar

$1-1-1987$

\title{
An Analysis of the Shift of Employment Toward Multi-Sectoral Services Industries in California, 1960-1980
}

Ayalew Adamu

Portland State University

Follow this and additional works at: https://pdxscholar.library.pdx.edu/open_access_etds Let us know how access to this document benefits you.

Recommended Citation

Adamu, Ayalew, "An Analysis of the Shift of Employment Toward Multi-Sectoral Services Industries in California, 1960-1980" (1987). Dissertations and Theses. Paper 526.

https://doi.org/10.15760/etd.526

This Dissertation is brought to you for free and open access. It has been accepted for inclusion in Dissertations and Theses by an authorized administrator of PDXScholar. Please contact us if we can make this document more accessible: pdxscholar@pdx.edu. 
AN ANALYSIS OF THE SHIFT OF EMPLOYMENT TOWARD

\section{MULTI-SECTORAL SERVICES INDUSTRIES}

IN CALIFORNIA: $1960-1980$

by

AYALEW ADAMU

A dissertation submitted in partial fulfillment

of the requirements for the degree of

DOCTOR OF PHILOSOPHY

in

URBAN STUDIES

Portland State University

1987 
TO THE OFFICE OF GRADUATE STUDIES AND RESEARCH:

The members of the committee approve the dissertation of Ayajew Adamu, presented March 13, 1987.

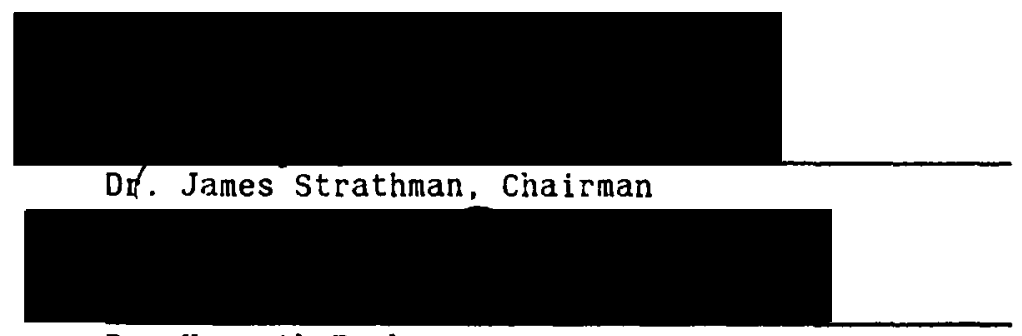

Dr. Kenneth Dyeker

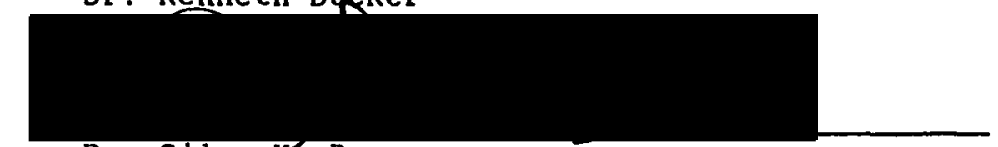

Dr. Giles $\$$. Burgess

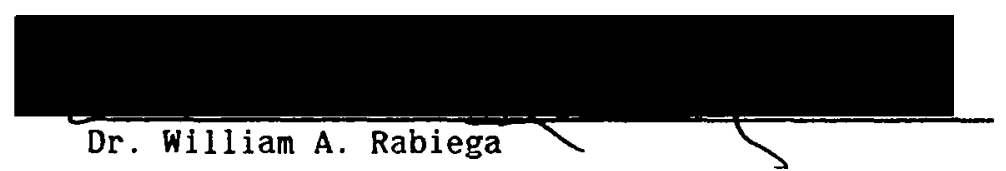

APPROVED :

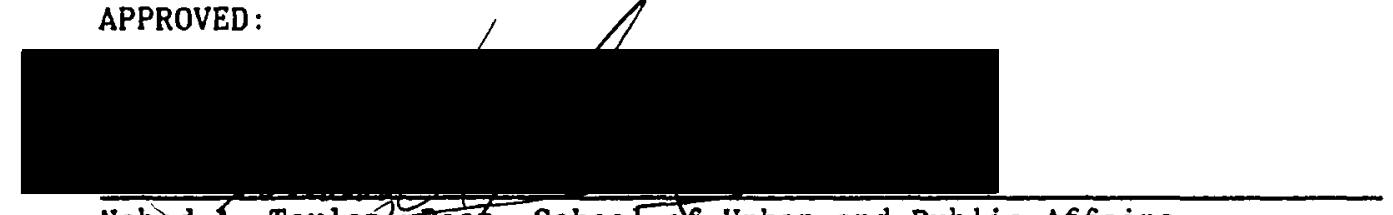

Nohad A. Toulan, Deah, Schoo of Urban and Public Affairs

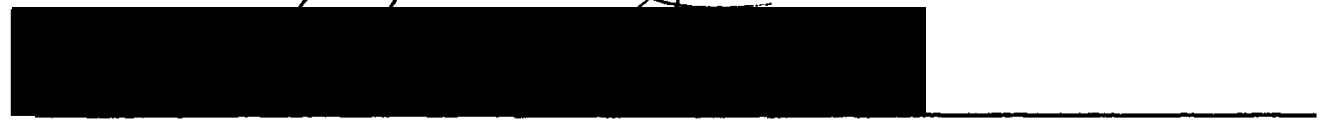

Bernard Ross, Dean, Graduate Studies and Research 
AN ABSTRACT OF THE DISSERTATION OF Ayalew Adamu for the Doctor of Philosophy in Urban studies presented March 13, 1987.

Title: An Analysis of the Shift of Employment Toward Multi-Sectoral Services Industries in California: $1960-1980$.

APPROVED BY MEMBERS OF THE DISSERTATION COMMITTEE:
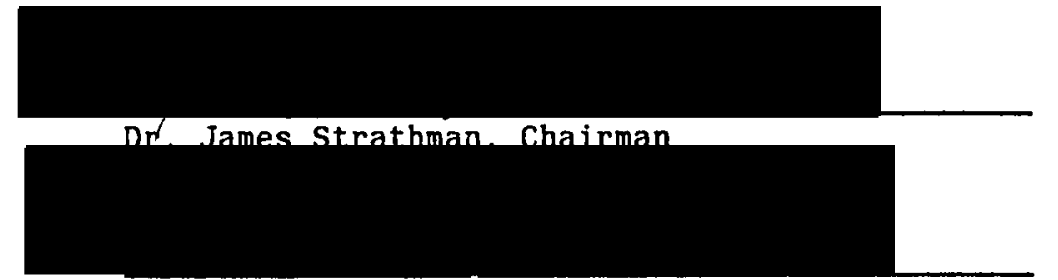

Dr Rennethrueker

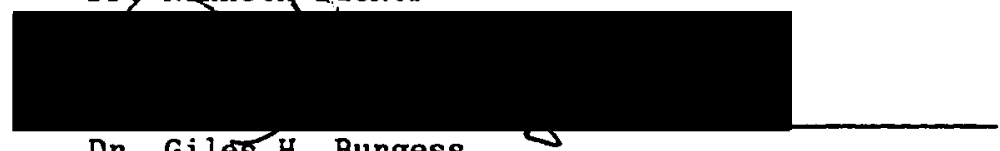

Dr. Giles H. Burgess

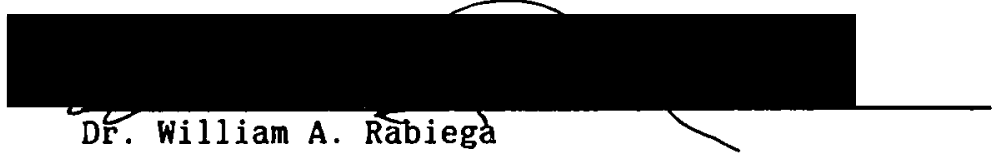

The structural change in the United States economy represented by the growth of the service sector has received a great deal of discussion and analysis in recent years. The purpose of this study is to identify the factors that have determined the growth of the separate service sectors (namely distributive, personal, social, and business) from 1960 to 1980 in the regional economy of California.

The research addresses many issues. First, a general discussion 
is presented of the structural change in the linited states economy toward a growing service sector. An obvious indicator of this change is the disproportionately higher rate of employment growth in the service industries as compared to the goods producing sectors. Second, it is pointed out that the current structural shift toward service affects the regional economy in shifting the labor force toward a service-oriented economy. Establishing the basic facts of this change, the research investigates the role of the four service industries in the region of California. This is carried out hy analyzing the market and industrial factors thought to be the determinants of this growth and the causes of decentralization within the metropolitan areas in California.

The empirical findings offer some answers to question of cause for employment changes in the service industries in the regional economy. The most important is that the growth of employment in the four service industries is not brought about by a single factor. Rather, growth is attributable to a combination of market and industrial variables, and the relative strength of the variables differs among the different service industries. The research also presents findings about the relationships among the service industries in terms of the employment changes in them.

In general the research provides a contribution to future discussions of the service industries in the metropolitan labor market of the regional economy, and of the nature of regional occupational growth arising out of the structural change described. 
ACK.NOWLEDGMENTS

I would like to acknowledge the following individuals whose assistance helped me immeasurably in the completion of this dissertation. First. I would like to thank Dr. James Strathman, who inspired me on the topic of the dissertation, and who. as the chairman of my committee, relentlessly provided his expert guidance. My gratitude to my chairman. not only for his efforts in this particular. but also for his role in my more general scholariy development. My appreciation also extends to the other members of my dissertation commitcee and to Dr. Nohad A. Toulan.

This dissertation was completed while I was recipient of the Multnomah County doctoral fellowship award, and I am very grateful to Multnomah County for providing the funds for this fellowship.

Finally, my appreciation goes to my family and most important to my beloved sister, Webayhu Adamu. 
TABLE OF CONTENTS

PAGGE

ACKNOWLEDGMENTS . . . . . . . . . . . . . . . . . . . . . iii

LIST OF TABLES . . . . . . . . . . . . . . . . . . . . . . v v v

LIST OF FIGURES . . . . . . . . . . . . . . . . . . . . . . . viil

CHAPTER

I INTRODUCTION . . . . . . . . . . . . . . 1

Approach . . . . . . . . . . . . . . . . 2

Scope . . . . . . . . . . . . . . . . . 3

History of the Economic Transformation . . . . 4

Employment in the Manufacturing Sector

The Rise in Employment in the Service Sector

The California Economy . . . . . . . . . . . 15

Sumary . . . . . . . . . . . . . . . 19

Organization of the Study . . . . . . . . . . . 19

I I LITERATURE REVIEW . . . . . . . . . . . . . . . 21

Theory of the Rise of Service Industry

Employment . . . . . . . . . . . . . . . 21

Stages of Economic Development

Changes in Occupational structure

Service Industry Employment vs. Manufacturing

Employment: A Comparison . . . . . . . . . 28

III THE TRADE OF SERVICES AS BASIC COMMODITIES . . . . . 35

IV A REVIEW OF EMPIRICAL RESEARCH . . . . . . . . . . . 43

Introduction . . . . . . . . . . . . . . 43

Resistance to the Business Cycle . . . . . . . 43 
$\checkmark$ THE DISTRIBUTION OF SERVICES IN THE REGIONAL ECONOMY ................ 57

VI SPATIAL ANALYSIS OF THE SERVICE INDUSTRIES . . . . 71

VII THE GROWTH THEORY AND DETERMINANTS IN THE SERVICE SECTOR . . . . . . . . . . . . . . . 78

VIII CONCEPTUAL DEVELOPMENT OF THE METHODOLGY . . . . . . 85

IX BORMULATION OF THE MODEL . . . . . . . . . . 90

Introduction .............. 90

Hypothesis ............... 90

Research Model, Phase One . . . . . . . . 91

Research Model, Phase Two . . . . . . . . 94

Specification of the Variables . . . . . . . . 95 The Dependent Variable The Independent Variables

Research Analysis... . . . . . . . . 99

X RESEARCH RESULTS . . . . . . . . . . . . 100

Introduction ............ 100

Model One: Regression Results for

Market-size Variables . . . . . . . . . 100 Distributive Industry Personal Services Business Services Social Services Industrial Variables

Sector Comparison of the Time-Series

Pooled Models . . . . . . . . . . . . . . . . . 115 Growth of the Local Market Industrial Variables 
Model Two: Regression Results for the

Regional Variables . . . . . . . . . . 120

The Location and Growth of the Aggregate Service Industries Over Time . . . . 127

The Chow Test . . . . . . . . . . . 132

XI CONCLUSIONS AND RECOMMENDATIONS . . . . . . . . . . 135

BIBLIOGRAPHY . . . . . . . . . . . . . . . . . . 140

APPENDIX . . . . . . . . . . . . . . . 147 


\section{LIST OF TABLES}

TABLE

PAGE

I Population Growth in California. 1960-1980 . . . . . . . 16

II Percentage Distribution of Employment in California from 1960-1983 (as percentage of total employment) . . . 1i

II A Comparison of Eleven Largest International Service Exporters, in Billlons of Dollars, 1980... . . . . . . 41

IV Regression Results for Model One. Equation One ... . . 101

V Regression Results for Model One. Equation Two ..... . 105

VI Regression Results for Model one. Equation Three . . . 107

VII Regression Results for Model One. Equation Four . . . . 110

VII Complementary and Substitution Relationships Among Industries in 1960.1970, and 1980 . . . . . . . . . . . . 112

I. Sector Comparisons of the Time-Series Pooled Models . . . 117

$X \quad$ Complementary and Substitution Relationships Among Industrial Variables in the Time-Series Pooled Model . . 119

XI Regression Results for Model Two: Distributive Services Industries . . . . . . . . . . . . . . . 122

XII Regression Results for Model Two: Personal Services Industries . . . . . . . . . . . . . . . . . . . . . . . . 123

XIII Regresslon Results for Model Two: Soclal Services Industries . . . . . . . . . . . . . . . . . . . . . 124

XIV Regression Results for Model Two: Business Services Industries . . . . . . . . . . . . . . . . . . . . . 126

XV Regression Results for Aggregate Service Industries Over Time . . . . . . . . . . . . . . . . . . . . . . . . 129

XVI Results of the Chow Test . . . . . . . . . . . . 133 


\section{IIST OF FIGURES}

FIGURE

PAGE

1. Percentage of Total Employment by Industrial Sector. 1850-1982 . . . . . . . . . . . . . . . . 7

2. Percentage Distribution of Full-Time Employment by Service Industry, $1947-1980$. . . . . . . . . . 13

3. Schematic Diagram of Migration of Population and Manufacturers, and the Consequent Decentralization of Services . . . . . . . . . . . . . . . 88 


\section{CHAPTER I}

\section{INTRODUCT ION}

Today it is widely recognized that the American economy is experiencing a major shift from manufacturing to service industry employment (Stanback, 1981; Singlemann, 1980; Be11, 1973; Toffler. 1980). While perhaps somewhat less dramatic than the nineteenth century Industrial Revolution, the current shift is nevertheless predicted to have an overwhelming impact on virtually every segment of the labor force. The service industries are broad and heterogitious, and, in contrast to other industries, their output is intangible.

Although the rapid growth in the services industries as the dominant source of employment and the concurrent decline in manufacturing have become dramatic only in recent years, the pattern has been with us since at least 1910. Fuchs (1965, p.1) explains the shift concisely. "The country is pioneering in a new stage of economic development. We are now a service economy." His statement acknowledges the United states to be the first nation with more than 50 percent of its workforce involved in the service industry, instead of in the production of goods. Moreover, service industry employment spans all income brackets, encompasses both skilled and unskilled workers, and includes both sexes and all ages. In short, its impact is much broader based than was that of the Industrial Revolution. 
this employment revolution and the degree of its impact, curiously little research has been done to explain the factors contributing to the unprecedented growth in service industry employment. The factors contributing to the growth of employment in the service sector, as well as the patterns of the spatial evolution of these industries, remain largely unknown. The focus of the present research, therefore, will be to define more accurately the role of the service industries in the regional economy. Specifically, this research will concern itself with two questions. First, what forces have contributed to the relative growth of employment in the four segments of the service sector (distributive, personal, social, and business services) in the state of California in the years 1960-1980. Second, the study will investigate the distribution of the diverse groups of service industries geographically over the years 1960-1980.

\section{APPROACH}

The four service industry classifications are introduced here in order to clarify the specific employment growth patterns in each of them. No two segments of the service sector are identical, because each poses unique constraints and opportunities for growth or decline in employment. In this research, the four service industries examined are:

- Distributive services, which includes transportation, communication, and wholesale and retail trade

- Personal services, which includes hotels, eating and drinking establishments, repair services, entertainment, and miscellaneous personal services

- Social services, which includes medical, dental, and health 


\begin{abstract}
services, hospitals, and other miscellaneous social services
- Business services, which includes banking, insurance, real estate, and miscellaneous business services.

Fundamental structural changes in employment have been occurring in the four service industries, and the nature and implications of these changes must be better understood in order to initiate a process of continued economic monitoring that will offer a basis for naking more informed decisions.

Recent studies underscore the impact of this shift. One U.S. Department of Housing and Urban Development study (1980) found, for example, that in cities experiencing population growth, trade and selected services account for 83 percent of the growth in employment. Conversely, in cities experiencing a decline in population growth, the loss of manufacturing jobs accounts for approximately 50 percent of the employment decline. However, for cities in decline, selected service industries have expanded to of fset approximately 12 percent of the loss in the manufacturing sector, demonstrating the potential importance of service industry employment in the coming decades.
\end{abstract}

SCOPE

In order to accomplish the overall objectives of this research, limits must be imposed on both its temporal and geographical scope. For the purposes of this study, then, the time frame will be limited to the twenty-year period from 1960 to 1980 . The year 1960 witnessed the greatest decline in manufacturing employment (150,000 jobs lost), and the greatest increase in service industry employment $(150,000$ jobs gained in such areas as transportation, communications, finance, in- 
surance, real estate, business services, and health care) (Black, 1980).

Regarding the geographical focus of this research, California has been selected for study. Several factors influenced this choice. First, California's economy is the largest state econony in the United States and, therefore, serves as a microcosm of the American economy as a whole. Second, California's economy is highly diversified, providing an excellent cross-section of the entire range of service sector employment.

Before proceeding to a presentation of the study itself and the literature on which it is based, it is necessary to put the problem in a clear context by presenting essential background information on recent structural changes in the U.S. economy.

\section{HISTORY OF THE ECONOMIC TRANSFORMATION}

Economic development is associated with technological progress; in fact, technology has always served as a foundation for a country's economic advancement. The history of the transformation of the U.S. economy is dominated by the introduction of technological innovations. The agricultural and manufacturing sectors and, most recently, the service sector, have all made contributions to the country's overall economic development. In order to clarify many of the implications of current economic changes for employment, it is important first to review historical changes in the agricultural sector.

Agricultural productivity has been rising due to technological improvements such as the use of advanced farm machinery, the implementation of new methods of cultivation, hybrid seeds, and more intense 
use of fertilizers. These changes, and the resultant increase in agricultural productivity, make large-scale, capital-intensive commercial agriculture feasible in the United States. However, the development of large-scale farming that embraces the techniques of mass production displaced a large portion of the traditional farm population and compelled them to migrate to the cities. This trend has reduced agriculture's labor force, displaced large segments of the population, and necessitated major changes in the population's lifestyle.

The shift of the population from the farm to the city largely explains urban growth (Thompson, 1970). This urbanization has altered the old occupational structures, thereby promoting mass production and consumption in the growing urban population. It is with this stage of economic development that the United States paved the way from an agricultural to an industrial economy.

\section{Employment in the Manufacturing Sector}

The manufacturing industries are defined broadly as those economic sectors engaged in the production of tangible commodities. Even though previous research into the manufacturing industries and their contributions to the U.S. economy has been analyzed in detail, this research has concerned itself primarily with growth per se. It has failed to anticipate the shift of employment from manufacturing to service industries and the implications of this shift for the overall economy.

The declining importance of the manufacturing sector first became apparent in the period following 1940, as shown in Figure 1 below. 
Looking at the historical trend of growth in the service industry since 1870 , maturation of this sector can be observed at the same time manufacturing began to decline in importance. 
Percent Employment

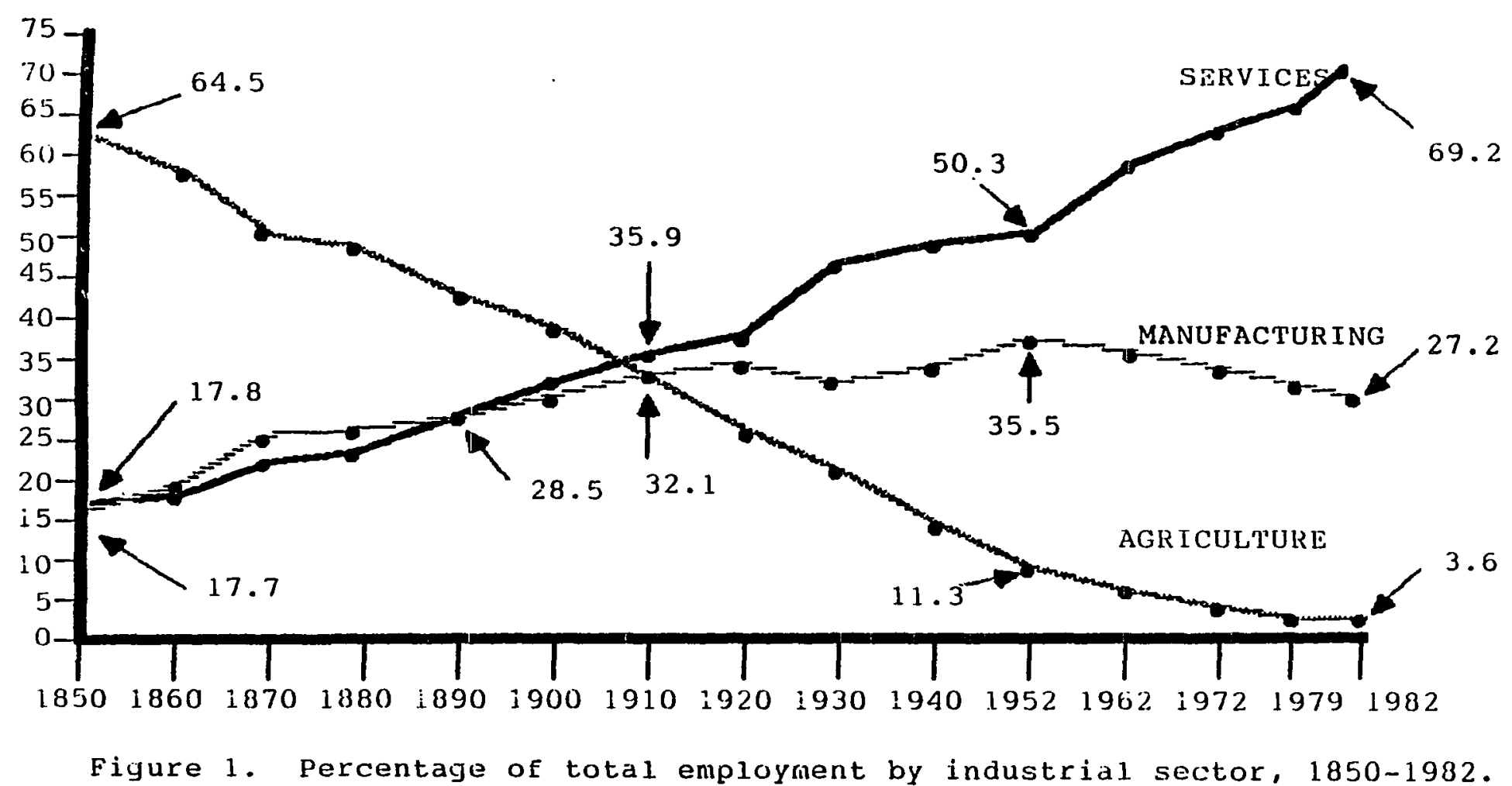

Source: U.S. Department of Commerce, Bureau of Economic Analysis; The National Income and Product Account of the U.S., 1929-74; and Monthly Labor Review, April, 1984. 
The industries depicted in Figure 1 are classified according to their functions. Agriculture includes forestry and fisheries, goodsproducing industries include mining, construction, and manufacturing. The remaining are classified as service industries. As igure 1 illustrates, the relative shares of the economy represented by the service and goods-producing sectors are initially related. The relationship is continuous from 1850 to 1860 ; from 1870 to 1890 the goodsproducing sector showed relative growth in employment while service sector employment declined. Around 1910, the three sectors cross one another, the service sector beginning a long and steady increase while the goods-producing sector and agriculture begin a long and steady decline. In 1982 the service sector peaks at nearly 70 percent employment, while in the same year, goods-producing industries had just 27.2 percent of the total, and agriculture only 3.6 percent.

Goods-producing employment peaked in 1947, with 35.5 percent of total employment, a level the sector has never regained. Agriculture's share of total employment declined from a high of 64.5 percent in 1850 to a level of only 3.6 percent in 1982 . It seems, however. that agriculture and service sector employment are similar in that changes in them occur apart from the overall economic situation. The former declines regardless of general economic conditions, while the latter grows continuously, again regardless of prevailing economic conditions.

The recent decline in manufacturing employment is due partly to the relocation of industry outside the U.S., and partly to the introduction of labor-saving technology. Reich (1983) discusses the impact of relocation on the manufacturing sector and suggests an increase in 
the tendency of American manufacturing industries to relocate in developing countries--Brazil, Singapore, Hong Kong, and Korea, for example--where labor is much less costly. Goods are being manufactured wherever their production is least expensive, regardless of national boundaries. Vastly improved communications systems have abetted this trend. According to Dunn $(1980$, p.40), these improvements have "altered the functional span of control, making possible control of complex operations which previously were monitored only imperfectly and with delay." Modern communications and transportation systems have eliminated much of the perceived risk in operating from remote sites, making foreign relocation economically attractive.

If decentralization is no longer seen as a problem, its study is nonetheless crucial to the larger problem of the decline in manufacturing employment. For example, Stanback (1981) feels that transportation and communication improvements, blue-collar labor costs, and accelerating technological developments comprise the greatest contributing factors to the overall pattern of manufacturing employment decline.

The wide spread of automatic technological systems in the production of manufacturing goods also reduced the demand for labor. In 1985 alone, 20 percent of auto industry jobs were expected to be replaced by automation, and 50 percent of automobile assembly was expected to be done by automated machines. (Monthly Labor Review. 1982). Industry's inducement to enploy such advanced technology is clear. A robot can work around the clock; it takes no vacations, does not call in sick, and does not become bored with routine. In an article published in Business (Apr1l and June 1983) Gengler and 
Ternsins calculated the total cost of a robot as $\$ 50,000$. Calculating at the rate of $\$ 6$ per hour, a manufacturer would recover the cost of the robot within two years. This compares with $\$ 20$ per hour currently paid for labor in the auto industry.

For those companies opting to remain in the United States, the use of sophisticated technology on the assembly line has reduced labor costs, increased productivity and allowed manufacturers to compete successfully with foreign manufacturers, whose labor costs are considerably lower than those in the U.S.

Gruenstein and Guerra $(1981$, p.23) accurately sum up the prevailing attitude on the future of employment in manufacturing:

A resurgence of manufacturing employment large enough to take up any appreciable slack in the . . . labor market seems almost as unlikely as a massive rise in farm employment and for much the same reason: stronger productivity growth in manufacturing and agriculture, while benefitting consumers greatly by increasing real purchasing power, eliminates jobs in these sectors.

\section{The Rise in Employment in the Service Sector}

The past several decades have witnessed a marked increase in the growth of employment in the service sector, and this growth has been considered part of a larger trend that bound manufacturing and service sector employment together. However, the rise in manufacturing employment did not keep pace with the tremendous growth in service sector employment. It ultimately became clear that manufacturing employment and service sector employment are not tied to one another after all, and that the service sector was becoming the dominant force in the U.S. economy.

The relative growth of employment in the private service industries is based on changes in technological and market factors. 
The location decisions and distribution of the public sector are based on political factors rather than by market demand factor, just as in the private service industries. At the same time public service employment expansion is not subject to the same cost constraints as those faced by private service industries. The main reason is that the expansion of public service employment is not motivated by economic factors in a strict operational sense, although it may well confer considerable social benefits.

The private service sectors on the other hand, reflects, in large measure, by the composition of final and intermediate demand under conditions of rising income, population and industrialization.

Being heterogeneous, the service industries are defined collectively as industries involved in producing intangible goods or in conducting invisible transactions. The service industries are diverse in terms of the services and the types of jobs they provide. Given this diversity, it might seem impossible to group and classify them meaningfully according to their business operations: however, closer analysis shows that there are effective ways of doing so. In fact, a number of attempts have been made to do just this, among them Katouzian's (1970), which suggested classification according to complementary services, old services, and new services. The most popular system of classification, however, is provided by singlemann and (1978), who suggest that the service industries can be divided into four groups. As previously noted, the present study accepts these four groups and employs them in its analysis. These industries are 
classified: (1) distributive services, (2) business services, (3) personal services, and (4) social services.

Figure 2, below, illustrates the speed with which employment in various segments of the service sector achieved prominence. 


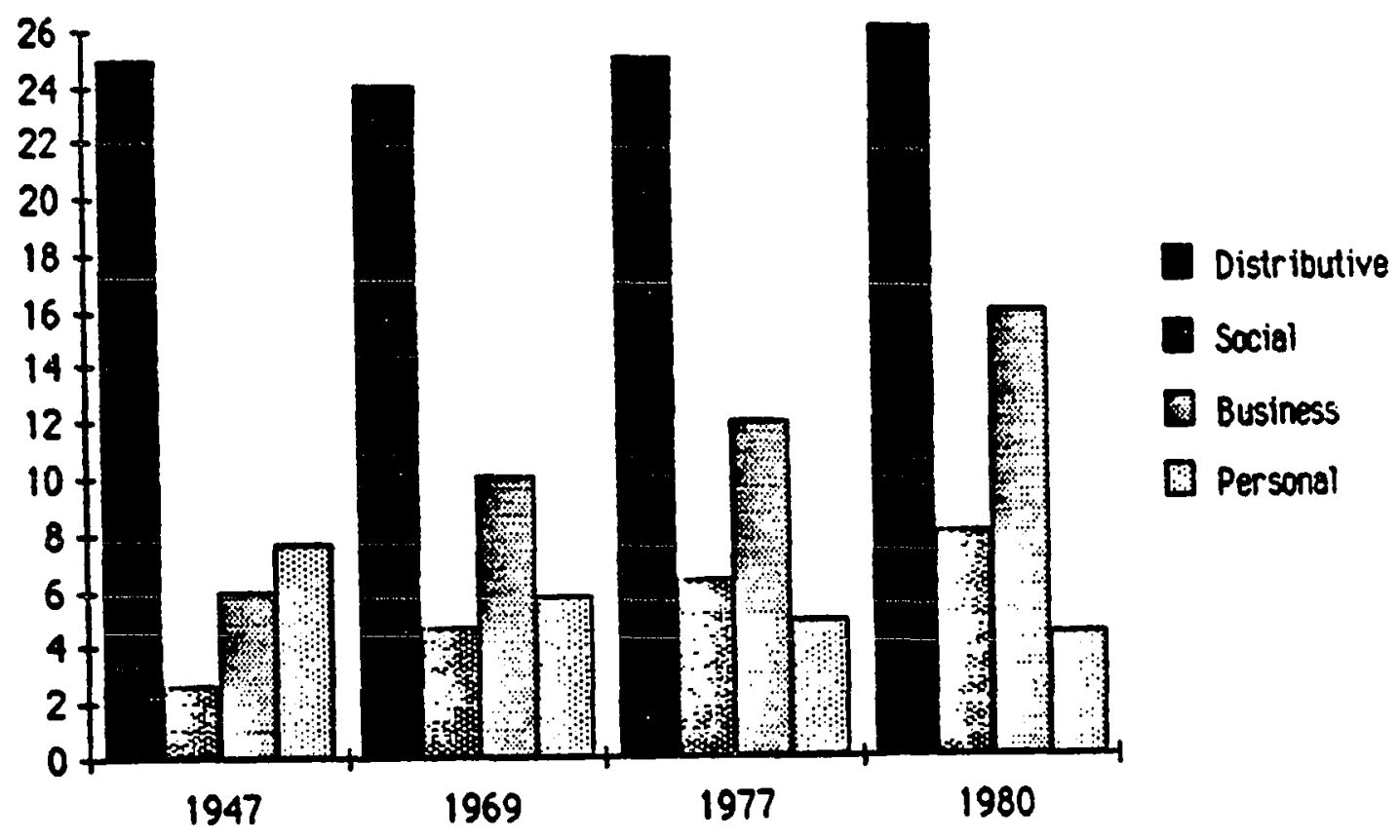

Pigure 2. Percentage Distribution of Full-time Employment by Service Industry, 1947-1980

Source U.S. Department of Comerce, Bureau of Economic Analysis, "The National Income and Product Amount of the United States and Survey of Current Business," July 1978 and July 1983.

Figure 2 shows that growth in service sector employment varies greatly among its various segments. For example, distributive service employment continuously increases even though the growth is small, ranging between 25 percent in 1947 to a higher 26 percent by 1980 . Personal services also declined, from 7.67 in 1947 to 4.90 in 1980 . Meanwhile, enployment in social services grew continually from 2.4 percent in 1947 to reach eight percent by 1980 . Surpassing all other 
segments of the service sector, business services employment rose from 7.8 percent in 1947 to 15.5 percent in 1980 .

The transformation of industrial employment toward the service sector has created some interesting changes in the job market. The service sector provides greater Job opportunities for a wider segment of the populace, since much of service eaploynent does not impose demands in the way of physical strength or technical expertise. Hence, women, the elderly, and those with varied educational backgrounds are finding increased opportunities in the service sector.

Another interesting development is the tendency of service industry jobs to move spatially as the general population moves. For example, the suburbanization of the $1960 \mathrm{~s}$ was accompanied by a shift of employment to the suburbs. Black (1980) found that in 1960 suburban employment grew by 44 percent, while central city employment decreased by seven percent. In the ten major cities he investigated, six experienced an absolute loss of 125,000 service jobs in 1970 . In the suburban areas surrounding these same cities, however, service employment increased a total of 600,000 jobs. Since the service Industries, like the manufacturing sector, are dependent on the demands of consumers, they tend to locate closer to their customers. Spatially, the suburbs have experienced both a massive growth in population and great increase in service employment, particularly in the area of business services (Erickson, 1983). Lewis (1983) also calls attention to spatial changes in the location of the service industries, referring to what he calls the "nultinucleated netropolis," where service industries, such as business services. flourish outside the central cities. Thus, the current structural 
changes in the growth of services employment within a metropolitan system has spatial rawifications, the extent of which this research proposes to examine in the state of California.

\section{THE CALIPORNIA ECONOMY}

The purpose here is to provide a review of the key economic trends in California during the past decades that are likely to exert an influence on the state's economic future. The following discussion treats the growth and development of the service industries and presents views on structural changes.

California has a diversified economy. It is also the most populous state in the nation and is among the highest in per capita income. Further, the state is considered to be the largest of the nation's regional economies. These characteristics include such things as size, industrial technology, occupational and desographic characteristics, and the presence of large, diversifled internal markets, such as Los Angeles, San Prancisco, San Diego, and several other large cities. Such diversity in the geographical and industrial base provides a rich source of study.

California is divided into 58 counties reflecting a broad spectrum of economic profiles, ranging from highly urbanized and technologically advanced to sparsely populated and agriculturally based. California has experienced rapid population growth and industrialization throughout most of its history, and this has provided a large 
growth from 1960 to 1980 .

TABLE I

POPULATION GRONTH IN CALIFORNIA, 1960-1980

\begin{tabular}{lccc}
\hline Year & $\begin{array}{l}\text { Total Population } \\
\text { (in thousands) }\end{array}$ & $\begin{array}{c}\text { Annual Rate } \\
\text { of Increase }\end{array}$ & $\begin{array}{c}\text { Percent 65 } \\
\text { and over }\end{array}$ \\
\hline 1960 & 15,800 & - & 8.62 \\
1970 & 19,960 & 416 & 9.03 \\
1980 & 23,700 & 374 & 10.20 \\
\hline
\end{tabular}

SOURCE: U.S. Bureau of the Census. $1960-1980$

The California population, as shown above, grew continuously from 1960 to 1980 . At the same time, the state's demographic characteristics, particularly the age group 65 years old and over, also grew, reflecting that California is a most attrtactive region for this age group. This 65-and-over age group has a high demand for a wide range of services, particularly social and personal services.

As was the case throughout the nation, the California economy has emerged from the advanced transportation and communications phases of economic development and has similarly passed through the agricultural and manufacturing phases. It is richly endowed with natural resources, trained manpower, and business institutions, and thus has managed to provide favorable job opportunities for its growing population. Even though it has increased its share of national employment in each of the major sectors, California has experienced a significant shift among the service industries, which have managed to absorb a 
large segment of the labor force--a trend similar to that in the nation as a whole.

TABLE II

PERCENTAGE DISTRIBUTION OF EMPLOYMENT IN CALIFORNIA FROM 1960 TO 1983 (AS PERCENTAGE OF TOTAL EMPLOYMENT)

\begin{tabular}{lccc}
\hline & & & \\
\hline Sector & 1960 & 1970 & 1980 \\
\hline Agriculture & 0.37 & 0.50 & 0.67 \\
Mining & 0.89 & 0.58 & 0.56 \\
Construction & 7.76 & 5.35 & 5.99 \\
Manufacturing & 33.36 & 27.14 & 25.38 \\
Services & 56.77 & 65.31 & 66.45 \\
\hline
\end{tabular}

SOURCE: County Business Pattern - $1960-1980$

If past trends are indicative of future behavior, employment in the service industries will continue to grow relative to manufacturing. In 1960 , employment in manufacturing was 33.36 percent, while services employment was about 56.77 percent. However, manufacturing declined steadily, and by 1980 it stood at 25.38 percent, far lower than services employment, which by then was 66.45 percent. Meanwhile, agriculture, mining, and construction show somewhat stable employment, with agriculture growing slowly and mining and construction fluctuating.

The recession of 1982 had its effects on the California economy, although it fared slightly better than did the nation as a whole. During this period, nonagricultural employment in California 
(including construction, nonaerospace manufacturing, and transportation) dropped by about 1.3 percent. In particular, all major California manufacturing industries showed a record decline between 1981 and 1982 (Economic Report of the Governor, 1983). However, at the same time, service industry employment grew faster than all other sectors of the economy, showing record new employment of 49.300 in 1982 and bringing the employment total to 2,290,300 jobs (Economic Report of the Governor, 1983).

While service sector employment in California has been growing in the past decade, this rapid growth has been accompanied by an increase in income. Median household income continued to rise in Calffornia from $\$ 3,490$ in 1960 to $\$ 9,302$ in 1970 , and to $\$ 18,243$ by 1980 . This rise in income will influence the growth of the service industries, since service industries are market oriented and prefer to locate close to the consuming population. Further, growth of the business and distributive service industries is characteristically related to the operation of an advanced industrial economy with a high degree of geographical specialization--characteristics reflected in the California economy.

Each service industry has its own occupational pattern, which has been and will continue to be subject to frequent changes due to the dynamic nature of the economy. In view of the critical importance of the service industries to achieving high levels of employment, this research will examine the factors relevant to the growth of each segment of the service sector and the trends in the geographical distribution of its growth. 
SUMMARY

Kuznets $(1980$, p.10) has noted that the growth of the service sector reflects "an advanced industrial economy or an advanced market." This view is shared by many, who note that this growth is widespread throughout the industriaized countries of the West and Japan. This trend is evidenced by its absorption of a large share of the workforce.

Major researchers in the field also agree that further study is needed in order to understand the ramifications of this shift and thereby develop strategies that address the long-term changes that will shape the economy. The most respected researchers, Kuznets (1980, p.25), have suggested the route future studies should take:

Is it correct to view the U.S. economy in the last quarter of the twentieth century as a "service economy"? If so, what forces have been responsible for the increasing tilting of the economy in the direction of services? An answer to these questions must be accomplished by an analysis of the dynamics of specific sectnrs that constitute the service arena: distributive, producer, social and personal services. The advantage of studying services separately is to develop specific forecasts for each sector.

It is to that end that the present research has been designed.

ORGANIZATION OF THE STUDY

Chapter II of this investigation will present a review of the literature dealing with the theory of the service industries in general and will discuss the causes of the shift from a manufacturing 
to a service economy. Chapter III will discuss the current rise of the service industries as an export-base phenomenon. The literature for this section covers the structural shift to a service economy that is occurring in the industrialized countries, not only in employment, but also insofar as the service sector is becoming an export industry which contributes to the balance of payments.

Chapter IV presents several sources in the literature indicating the service industry's resistance to the business cycle. It also compares the service sector's resistance to the business cycle with the effects of the cycle on manufacturing. Chapter $V$ presents the service industries' distribution in the regional economy. The literature in this section provides a brief account of the geographic distribution of the various service segments.

Chapter VI describes the spatial preference of the service sector. The literature presents a detailed review of the separate service segments' choices and criteria for location. Chapter VII presents the major theories regarding the factors which influence the growth of the service industries. Chapter VIII presents the conceptual development of the methodology to be employed in this research. Included is a reveiw of the major factors revealed in the discussion of the theory of the service industries. Chapter IX presents the development of the model based on the conceptual development of the methodology, and Chapters $X$ and $X I$ present the results of the research and the conclusions. 


\section{CHAPTER II}

\section{LITERATURE REVIEW}

This chapter surveys the literature documenting the rise of service industry employment, provides essential background material, and shows the degree to which the present research is a logical extension of work done in the field for nearly fifty years.

Several types of material are presented in this chapter. First. there is literature which discusses the theoretical basis of the shift toward the dominance of the service sector. Second, there is literature describing previous empirical studies whose results have helped to validate (and, in some cases, refute) the theoretical work. Together these two bodies of literature comprise a profile of service industry employment as it is known today.

\section{THEORY OF THE RISE OF SERVICE INDUSTRY EMPLOYMENT}

\section{Stages of Economic Development}

Allan Fisher's studies during the mid-1930s, generally considered to be the pioneering effort in the study of service industry employment, document both the early shift from agricultural to manufacturing employment and the subsequent transition to service industry prominence. Being the first real attempt to provide a comprehensive theory of the rise of service industry employment, Fisher's work became the starting point for the many studies that followed. According to 
Fisher, the service industries include the following: travel, amusement, government and personal services, and health care (Fisher, 1930). Fisher stated that as an economy develops and per capita income rises employment in the service sector will increase. One of the most notable of Fisher's disciples was Colin Clark. Writing in the 1940s, Clark modelled his work after Fisher's, finding that growth in the service sector is related to the overa!l growth in per capita income. Clark's major contribution was expanding Fisher's rather limited definition of what constitutes service sector employment. Clark's new definition includes such areas as wholesale and retail trade, finance, and transportation. Fisher and clark agree that development of each sector progresses in stages, which include transitions from agricultural to manufacturing and then to service industry dominance (Clark, 1940).

Beam (1946) examined patterns and stages of growth for industrialized nations. First. Beam divided each country by the proportional dominance of primary occupations, secondary occupations, and service industries. Then, in order to identify the pattern of growth in each country's economy, he discussed each of the three employment sectors as separate stages. In this way he found that the transformation of employment from the agricultural sector to other sectors is accompanied by technological innovations which increase agricultural productivity and output. These technological advances improve agricultural productivity, in turn generating greater urban per capita income, which then results in greater agricultural income.

Beam then examined the effects on per capita income of the three stages of development--agriculture, manufacturing, and the tertiary 
industries. He found that technology must be employed in the primary sectors in order to raise the standard of living. Doing so tends to reduce the proportion of the labor force engaged in agricultural occupations. thereby raising per capita income. In the United States, a higher per capita income is found in areas where a large proportion of the work force is employed in service occupations. This trend may also be seen in Western Europe. Beam concludes that per capita income runs from low levels during the agricultural phase of development, to a high level during the manufacturing phase, and then to a very high level once in the service sector phase of development. This finding is consistent with those of earlier studies.

Researchers subsequently confirmed the validity of the Fisherclark theory, but only after modifications were made by Bauer and Yamey (1951), and Oshima (1971). These studies conclude that the theory is correct as a general rule, but that it does not hold in every case. One modification posits a condition wherein not all types of service industry employment rise above the levels of manufacturing employment. Selected types of "old" service industry occupations (e.g., domestic services) are likely to remain at low employment levels, even when the overall trend is toward increases. The studies also point out instances in which a country may altogether skip the middle step of the transitions (the manufacturing phase) due to an abundance of natural resources.

Kuznets (1958) researched the theory of regional income differentials and documented the relationships between higher income and elevated levels of manufacturing employment, and between lower income and the level of agricultural employment. He examined these relation- 
ships by grouping states by per capita income in the years 1920,1930 , 1940, and 1950, and then dividing the states' economic structures by agricultural an' manufacturing sectors. In this way, Kuznets observed that in states where agricultural employment was proportionally higher than levels of manufacturing employment, there was a correspondingly lower level of income. On the other hand, in states with higher levels of manufacturing employment and lower levels of agricultural employment, there were correspondingly higher levels of income. Kuznets' findings confirm the pattern of per capita income growth suggested by Fisher.

Sabolo (1975) also examined the Fisher-Clark theory for the periods 1900-10 and 1960-70, studying both underdeveloped and developed countries. His findings again confirn the Fisher-Clark hypothesis when applied to such highly developed countries as the United States, Belgium, Canada, New Zealand, and the United Kingdom; however, he found that the theory does not accurately reflect the situation in developing nations.

Another theory in vogue during mid-century was the "export-base" theory, which differs from the Fisher-clark theory in its point of view. Export-base theory sees service industry growth as responding to growth in the manufacturing sector, and not as a separate growthpropulsive force. Therefore, if manufacturing increases, service employment will also increase; if manufacturing decreases, then so does service employment.

Daniels (1983) compared the service and manufacturing industries and agreed with the general idea that manufacturing benefits the growth of service industries. However, Daniels argued that producer 
services have expanded against the general trend, indicating the need to investigate the behavior of individual service industries. Daniels suggests that it is wrong to assume manufacturing alone to be the prime mover of economic growth, thereby considering service sector expansion to be purely ancillary to idustrial growth. He states for example, that the lack of available services hinders growth in manufacturing, and that development of the industrial economy is impossible without an adequate service sector.

Recent studies have questioned the validity of assumptions about the role of the service sector as expressed in the export-base model. One such study was conducted by Gruenstein and Guerra (1981). Their data showed that, at the time of writing, service sector employment accounted for more than half of the labor force, while manufacturing employment had declined. A study by Knight (1973) arrived at similar conclusions, i.e., that service-export activity increased the share of total metropolitan employment from a level of 36 percent in 1940 to 44 percent in 1960, while manufacturing posted large losses during the same period.

The export-base theory states that basic industries export their goods and generate revenues outside their home regions, while nonbasic industries (service industries) generally feed their growth on the local market. However, the current development of service industries such as information processing, are not easily accommodated by the export-base theory. Regarding the argument that the service industries are transitory and unpredictable, Daniels (1983) responds that many small manufacturing industries are at the same time short-lived.

Beyers, Alvine, and Johnsen (1985) examined the export of 
services in the Puget Sound region of Washington State. They hypothesized that some service growth may be attributed to services exportcd outside both the region and the state. To test their hypothesis, they conducted personal interviews with business executives from several service industries, including transportation, utilities, communications, finance, insurance, real estate, business and professional services, and higher education. They interviewed the executives of more than 1100 firms, focusing on current levels of service exports and changes in these levels over time, taking into account location and site variables, corporate history, and impediments to developing export markets. Their results show that Puget Sound's services are traded on a wide geographical market, even though there are differences in the degree of export business among the different industries in the service group. In the 1100 firms interviewed, it was found that about 55 percent of their business was done outside of the region. The destination of these service exports included 47 of the 50 states, as well as countries on the Pacific Rim and in Western Europe. As a result, in 1984 the number of jobs resulting from these service exports was larger than the number of export-related manufacturing jobs in central Puget sound. In order to study the pattern of service-export growth, Beyers and Alvine compared the results of interviews conducted in 1979 with those conducted in 1984 and found that between 1979 and 1984, the level of service exports grew from 46 percent to the current level of 55 percent.

\section{Changes in Occupational Structure}

A recent study by Katouzian (1970) classifies service industries 
according to similarities in consumption and production; covering the period 1871-1921, its scope is expanded to include Western Europe. His findings indicate that there are "new" services (health fields, entertainment), "complementary" services (banking, finance, transportation, wholesale and retail trade), and "old" services (domestic services). The new services, he found, are in greatest demand during stages of high consumption. Thus, consumption of these services $r$ ises with a concurrent rise in income, growth of population, and industrialization. Growth of complementary services, he found, complemented the demand for manufacturing services. 0ld services were found to decline as a country's per caplta income rose. This last finding has been tested and confirmed by stigler (1956).

Another important study, this one focusing on the occupational shift accompanying the rise in service industry growth, was conducted by Singlemann and Browning (1980), who examined 11 major occupational groups in 37 industries during the period 1960-70. Their findings reflect growth patterns among professional, semi-professional, clerical, and service workers in general, and conclude that the occupational shift has had a particularly harsh effect on farming and blue collar occupations, while white collar employment has increased dramatically.

A final study, completed by Bell (1973), again pertains to the occupational shift. Bell's work is noteworthy, because it examines the 1ssue from a sociological point of view. Bell's coining of the term "post-industrial society" is indicative of his views on the future of the goods-producing sector of the economy. His view is that control of technology and technological assessment and the creation of 
a new, intellectual technology are the key sociological factors in changing occupational structures.

SERVICE INDUSTRY EMPLOYMENT VS. MANUFACTURING EMPLOYMENT:

A COMPARISON

Another category of research compares manufacturing and service sector employment statistics. Fuchs (1966), for example, examines the increase in service sector employment between 1950 and 1960 . Comparing the fields of education and health with several goods-producing industries, he discovered that emplayment in education alone was higher than in the steel, copper, and aluminum industries combined. Similarly, employment in health-related fields was found to be greater than total employment in mining in 1960. This type of comparison has led researchers to cominent that servije industry employment, on the average, makes much better use of well-educated workers than does manufacturing.

Ginzberg (1968) is another whose work focuses on comparative statistics, docunenting the impact of industrialization on employment. His study shows that in 1929, 24 million manufacturing workers produced $\$ 122$ billion in output, while in 1963 , 25 million workers produced $\$ 311$ billion in output. In constrast, the service sector's value-of-service output increased during the same period from $\$ 60$ to \$181 billion, while service sector employment expanded from 23 to 42 million. SImilarly, the percentage of GNP represented by service sector employment rose from 33 percent in 1929 to 37 percent in 1963 .

Urquhart (1984) studied the shift in employment to the service sector and found that, in the United states, it has been going on for 
more than 30 years. Using data from a national sample survey of 60,000 households conducted by the Bureau of the Census for the Bureau of Labor Statistics, he examined the intersectoral employment shifts by analyzing each component of the service sector. He then compared the employment distribution patterns between 1850 and 1982 by sector. noting a continual growth in service sector employment, while agriculture's share of total employment declined steadily. The service sector accounted for more than 70 percent of total U.S. employment in 1982, while in the same year, employment in agriculture declined to only four percent. The manufacturing sector increased its share of total employment until 1952, when it began declining, amounting in 1982 to only one-fifth of total employment. Overall, the goodsproducing sector grew by about 25 percent during the period, while its share of total employment declined from 36 to 27 percent. The service Industries are growing more quickly, however, at the time of the study holding an employment level of about 69 million, more than two-thirds of total employment.

Urquhart differentiates between service sector growth attributable to agriculture's decline, on the one hand, and that attributable to manufacturing's decline. Since the late 1960 s, the relative decline in manufacturing employment appears to be greater than that for agricultural employment, while agriculture's share of total employment seems to have stabllized. By dividing the period. Urquhart found that prior to 1967, the shift of employment toward the service sector was attributable to the decline in manufacturing. From 1967 to 1979, the goods-producing share of total employment declined by about 4.5 percent, while agriculture's share declined by only 1.7 percent. 
These figures contrast with those for the period 1952-67, however, when agriculture declined by six percent while the goods-producing industries declined by only 0.8 percent.

Urquhart also examined the relative shifts of employment among the three sectors. Analyzing the data by industry, he found that from 1967-79, the goods-producing sector accounted for more than 70 percent of the shift to services, a loss of 4.5 million jobs, compared to a loss of only 1.7 million jobs in agriculture.

Kellerman (1985) conducted a detailed study of economic transitions from manufacturing to the service sector in industrialized countries, identifying the major economic changes for each nation. In the study, Great Britain and the United States showed a low level of employment in the primary industries, with very sharp declines in Japan, Italy, and France. Japan's slow decline in agriculture is attributed to that country's more recent exposure to modern industrialization. However, all seven of the industrialized nations studied have completed the transformation from agricultural to industrial dominance. Upon completion of industrial development, the service sector eventually emerged as the dominant employer in each of the countries studied. Further, Kellerman analyzed employment in finance, insurance, and real estate, and found them to surpass agriculture in percentage of total employment.

In each of the countries, however, the transition differed somewhat in the manner and timing in which it came about. For example, in Canada and West Germany, the transition occurred in 1980. The service sector was found to grow in a consistent fashion in all seven countries. Kellerman concludes: 
Urban and national consequences of this transformation also need further study. The questions of location, spread and interaction of services within a metropolitan system and through a national urban system may turn out to be crucial for further urban and economic growth. (1985, pp.141-142)

The economic changes are also reflected in figures for the nation's shift from blue-collar to white-collar employment. This shift in the occupational structure of the labor force reflects increases in the investment of human capital required by the growing service sector.

Hill (1977) examined the concept of services, providing a useful defintion of the term. His paper is not only concerned with services and how they differ from goods, but it goes on to analyze the units to which the prices of services refer and which their volume can best be measured. Hill argues that economists have for too long dismissed the distinction between goods and services as trivial.

Economists, meanwhile, are prone to either deny the existence of services by asserting they are in fact goods, or, perhaps even worse, to treat them as special kinds of "immaterial" goods. Hill maintains that this is highly misleading and that the neglect of services in economic theory is all but incredible given the prominent role of the service sector in contemporary economics.

Hill defines a service as a change in the condition of one economic unit as the result of the activity of another economic unit. Since they represent changes over time, the dimensions of services are quite different from those of goods, which are considered to be material objects. Accordingly, goods and services belong to different categories.

Services are consumed as they are produced, in the sense that the 
change in the condition of the consumer unit must occur simultaneously with the production of that change by the producer unit. Because services are not like goods, which can be stored, services necessitate immediate transactions between the producer and the consumer. Therefore, in order to develop appropriate economic theory, economists need to devise a mechanism by which to distinguish between services and goods.

Marshall (1985) examined the contribution of private services to regional employment in the United Kingdom during a period when manufacturing jobs were being lost throughout the country. In addition, he reviewed the United Kingdom's industrial policy initiatives toward the manufacturing industries, which were then designed to help attract employment in "assisted areas." However, U.K. policy did not effectively attract manpower or otherwise assist the growth of either manufacturing or service employment in the designated regions. One likely reason for this is that assistance was focused mainly on manufacturing industries and not on the growing service industries. Another reason lies in the lack of understanding of the service economy, as manufacturing was conventionally used as the yardstick for regional development.

Marshall develops an argument for an appropriate regional policy toward service industries by analyzing policy implications, such as employment and location changes in service industries. In 1981 , private service industry employment totaled 8.7 million jobs, or 40 percent of total employment, and this dominance of private service employment made the sector attractive to regional policy planners intent on creating jobs. 
Within the service sector, employment has grown at a record level. For example, advertising, finance, and banking have increased their employment in the U.K. by 332 percent, 122 percent, and 110 percent, respectively, between 1959 and 1981. These three private service industries also provide employment opportunities on a regional basis, although not at a level comparable to that in central areas. In regions close to London, private service industries are well established: further, there has been considerable decentralization of service employment to the southeast of London. During the decade 1971-81, private service employment grew by about three-quarters of a million jobs, and even during the 1978-81 recession, more than 150,000 jobs were created in the provincial regions.

Business service firms have become increasingly cost-conscious and this has led to relocation for the purpose of reducing costs. Information technology and improved productivity have led to mobile administrative employment. In banking, diversification has encourage decentralization and greater autonomy for regional centers. This, in turn, has provided more authority to the regional of $\mathrm{fices}$ and has made reglonal divisions more responsive to local demand. In both insurance and banking, technology has assisted relocation to sites outside of London.

Marshall goes on to say that the economic rationale for the expansion of service employment is that the advanced nations are evolving toward a post-industrial economy. Not only must this be recognized by governments, but regional policy must be developed in such a way as to spread the service economy around. The recent implementation in the U.K. of regional service policy reflects a more 
favorable attitude toward private services, including as it does such features as financial assistance and automatic assistance designed to encourage the service economy.

Lewis (1973) states that if the present trend continues the U.S. economy will be dominated by the service sector by the year 2000 . Industrialized America, followed closely by the remainder of the West and Japan, is moving toward an entirely different style of society. says Lewis, one in which manufacturing employment will in the next century be no more prevalent than agriculture is now. Lewis goes on to discuss the reasons given by Fuchs for low productivity in the service sector. Lewis argues that growth in productivity in the service sector will continue to lag, but will accelerate faster in the future as a result of technological advances. In recent years, technological innovations have flowered on a wide front, in electronics, computers, office machinery and other areas, which provides opportunities to improve the efficiency of service industries.

White-collar employment, says Lewis, exceeded blue-collar employment in the U.S. for the first time in 1957, a milestone for a transformation that is widespread in the industrialized nations. He maintains this is largely due to an advanced economy. Clearly, this rise of the white-collar worker is closely connected with the expansion of the service sector.

The economist as well as the historian of the future should by then be better disposed toward services because he should be using an economic theory as well as statistical material which is capable measuring service activity objectively, and which is not biased as is our contemporary economic theory and statistical treatments which is in favor of goods. (Lewis, 1973, p.8) 
CHAPTER II I

THE TRADE OF SERVICES AS BASIC COMMODITIES

It would be difficult to define conceptually the nature of service industries--whether they are basic or nonbasic industries. The problem with such classification is that it requires an industrial survey of the service industries to identify the degree to which each sector is basic or nonbasic or both. With one notable exception (Beyers 1985), these surveys have not been done.

The traditional tool used to analyze economic development is the popular "export-base" theory addressed by Charles Tiebout (1962). In export-base analysis, the economy is dipicted as an open economy dependent on the export of goods produced by the manufacturing sector.

However, export-base theory has not held up well in light of recent changes in the structure of the U.S. economy. Testimony in a hearing before the Subcommittee on International Trade 15.2058 and S.2051: 1982) maintains that U.S. trade in merchandise is showing a deficit, while trade in services has been consistently increasing over the years. In 1981, for example, service industries recorded a balance-of-trade surplus of $\$ 41$ billion, this in contrast to a $\$ 40$ billion shortfall in the trade of goods. The subcommittee report further states that past trends prove that the contribution to the U.S. balance of payments by the international trade of services is steadily increasing. From 1980 to 1981, for example, service exports 
grew from $\$ 121$ billion to nearly $\mathbf{5 1 4 0}$ billion, an increase of more than 15 percent.

The report also states that service industries are generating over half of the nation's gross domestic production and provide jobs for more than half of employed Americans. In fact, the inportance of these industries to the U.S. economy has grown steadiiy from 1970 to 1980. expanaing by more than 18 million the number of jobs as compared with only 2.5 million jobs created by the goods-producing sector of the economy. The expansion of the service sector, as measured by the numbers of jobs created, accounted for an extraordinary 87 percent of the total of Jobs created during the ten-year period.

At the same 1982 subcomittee hearing, Sanuels M. Ehrenhalt, from the U.S. Department of Labor, addressed himseif to the Importance of the service industries in the realm of international trade. He stated that the sales of various services abroad have helped the $U$. $S$. balance of payments by turning a $\$ 28$ billion merchandise trade deficit into a $\$ 7$ billion accounts surplus in 1982 .

Sapir (1982) outlined a service trade policy for the $1980 \mathrm{~s}$ in an article published in The Columbia Journal of World Business which described problens facing the United states in increasing international service trade. A detailed analysis of the service industries shows that in the United States, services have a comparative advantage over the trade of merchandise. Sapir concludes that the factors deternining the composition of goods trade also apply to service 
(IMF). Sapir tested various traditional hypotheses on trade in the service sector, and his results show that traditional trade theories apply not only to goods, but to services as well. Further, he saw that the traditional economic factors applied to the analysis of trade in merchandise were also the primary determinants when analyzing the service trades. Looking at the service industries as a whole, he concludes that despite several trade barriers, it is possible that the theory of comparative advantage applies to the service sector in much the same way it applies to the goods-producing sector.

Sapir argues that current technological innovations will likely change this attitude as a result of trans-border data flow and telematic communications. Under the influence of sophisticated technology, we are seeing an expanston of service trade in the international arena. On the negative side, however, many of the current advantages enjoyed by the service industries are seriously hampered by trade restrictions. Hewitt (1983) also discusses the expansion of international trade in services. He states that as the United States economy enjoys an advantage in the service sector greater than ever before, increasing trade barriers will inhibit international trade in services.

Three service industries--shipping, insurance, and banking-account for more than 20 percent of total world trade. Hewitt points out, however, that it is becoming more difficult to expand service industries internationally. Merchandise trade is governed by the rules of the General Agreement on Tariffs and Trade (GATT), but so far there is no international agreement on service trade. Meanwhile, service trade worldwide is growing; from $\$ 69$ billion in 1969 to a 
record $\$ 375$ billion in 1980 . Basing his views on current patterns, William E. Brock, United States trade representative, stated that if trade barriers are lifted, it is likely that service trade will exceed the growth of trade in goods within the current decade (International Management, 1982).

Feldman and Proctor (1983) emphasize that it is in the best interest of the United States and the other industrialized nations to resolve the problem of trade barriers that restrict the trade of services. Even in times of recession, when the U.S. dollar is at inflated values (which contributes to an expanding deficit in merchandise trade), service trade surpluses have continued to rise. The article goes on to highlight the advantages to the United States of international service trade and the growing importance of the service industries to the balance of payments.

Palmer (1985) examined international business in the consumer service industry and found that its operations abroad are growing more quickly than the international trade of merchandise. International consumer service trade is growing by about 17 percent annually, while trade in merchandise grows by only six percent per year. Among the fastest growing of the consumer services is the fast food restaurant business. Enjoying fewer trade restrictions than other service industries must contend with, consumer services are expanding more quickly. In 1979, an American firm McDonalds's, led the way in international fast food operations, followed by Kentucky Fried Chicken. In West Germany alone, McDonald's has 133 outlets, and the corporation reports that 35 percent of its profits are generated in Western Europe.

The United States National Study on Trade in Services (1982), a 
report submitted to the United Nations General Assembly, analyzes the growth of the domestic service economy and 1 ts role in international trade. It reports that in 1948 , the goods-producing industries contributed 46 percent of the U.S. GNP. At the time of the report's preparation, the goods-producing industries accounted for only about 33 percent of the U.S. GNP. Meanwhile, over the past 35 years the service sector's share has increased from a little over half of GNP to fully two-thirds today.

The study also addresses the historical pattern of United States labor distribution and follows the shifts in employment from agriculture to manufacturing and on, then, to the service sector. The study shows that during the period studied, there was a steady decline in the percentage of workers employed in goods-producing industries. However, productivity and consumption have risen steadlly. This rise in productivity has made it possible to maintain a high level of output with relatively few additional workers. As a result, employment share, which was at 37.8 percent of total nonagricultural employment in 1960, dropped to 28.3 percent in 1980 . Meanwhile, the share of total employment contributed by such industries as transportation, public utilities, wholesale and retail trade, finance, insurance, real estate, and other service occupations, rose from 62.2 percent in 1960 to 71.6 percent in 1980 . Generally speaking, over the past two decades about 86 percent of fob openings in the United States have been in the service sector.

After analyzing the historical patterns in employment in the three sectors of the U.S. economy, the study reports on the recent explosive growth of service trade worldwide, employing for analysis 
balance-of-payments data obtained from the International Monetary Fund (IMF). The study found that the value of service industry output, excluding foreign investment earnings, exceeded $\$ 350$ billion in 1980 . It was also found that service exports were, in actuality, substantially greater than was reported in IMF data. This is reportedly due to difficulties in collecting data for various service industries. However, this undervaluation of service trade is also widespread among GATT member countries. Another difficulty with the figures grows out of problems with accurately calculating the export of services, since non-IMF countries, and even some member countries, fail to report figures on the export of services.

In many countries, service-industry exports are expanding on a world wide scale. Recognizing this growth, the European Economic Community (EEC), after resisting the liberalization of service trade for more than a year, began backing the idea of multilaterial servicetrade agreements (The Financial Times, October 19, 1983).

The UN study, Table III below, explored the growing demand for the international trade of services and the reasons for the international focus on the service industries. 
TABLE III

A COMPARISON OR ELEVEN LARGEST INTERNATIONAL SERVICE. EXPORTERS, IN BILLIONS OF DOLLARS, 1980

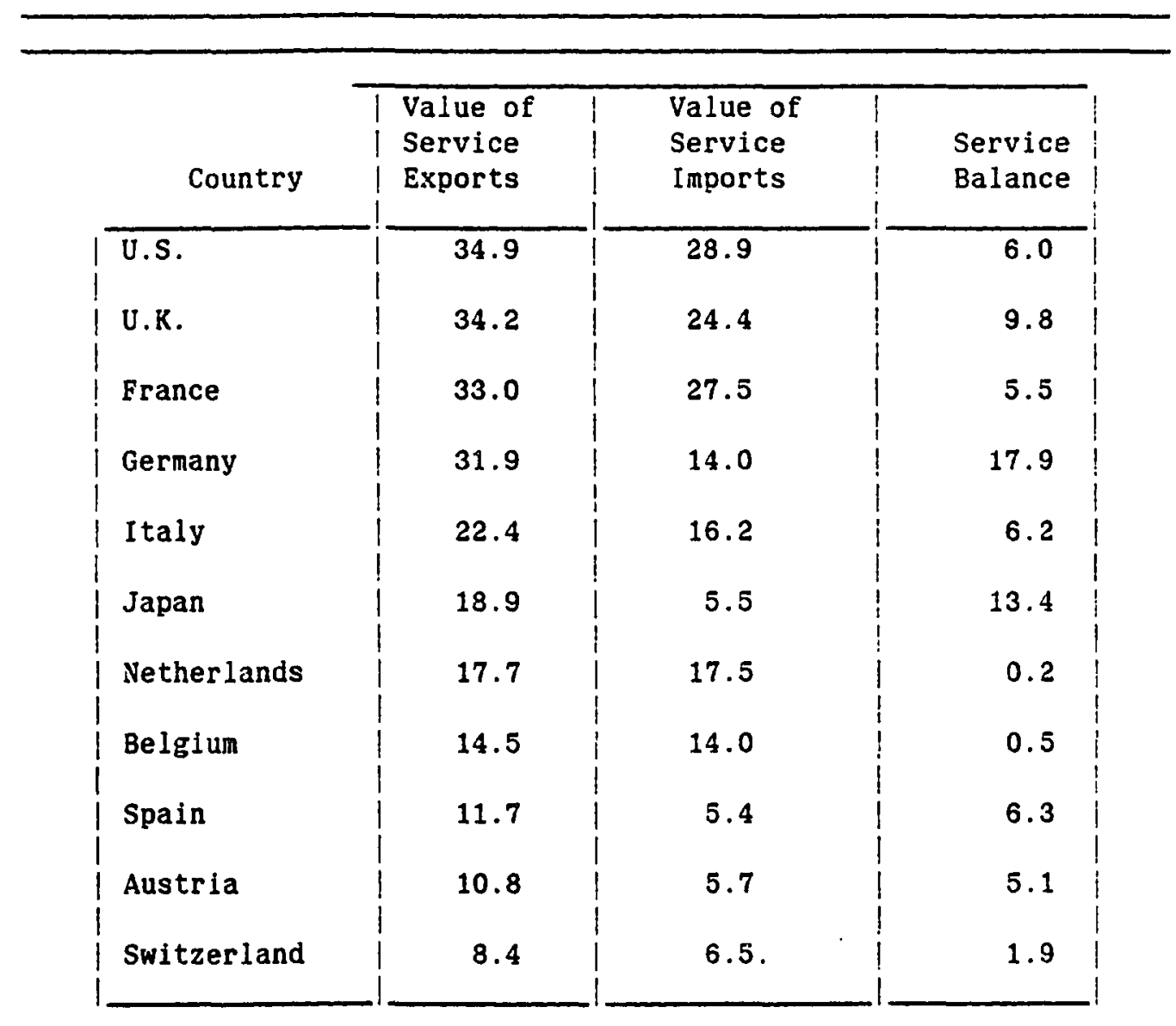

SOURCE: U.S. National Study on Trade in Services, October 1984

The study explains the pattern of expanding service trade in terms of two primary factors. The first is that the types of goods traded have become much different in recent years. In the past, goods traded internationally were maintained by the importing country without the need for assistance on the part of the exporter. All that was necessary was for the importer to maintain the capacity to complete the transaction and effect importation. Lately, however, 
this has changed considerably. Because of the growing sophistication of a great many manufactured imports, it has become necessary for continued service input from the exporting country in order to keep the products operational, since maintenance capabilities are frequently not avallable in the importing countries. For example, the purchase of sophisticated military equipment, computers, and advanced communications systems require a continuous import of parts and service experts.

The second of the primary factors encouraging the growth of international service trade is a trend toward considering information as a commodity and the rise in the importance of this "commodity" relative to manufactured goods. Such information includes knowledge, skills, and technical and general information, all of which have become increasingly important in world trade since the integration of the computer and communications technology into the international economy. This integration has expanded trade in both goods and services; accordingly, the data listed for the countries in Table III, above, represents an average growth rate of about 17 percent in the trade services. 
CHAPTER IV

A REVIEW OF EMPIRICAL RESEARCH

INTRODUCTION

Although by far the largest number of empirical studies nave concentrated on the distribution and growth of service industry employment, a few have dealt with service industry resistance to the business cycle. These studies have added to our understanding of the service sector employment phenomenon and therefore merit passing mention here.

RESISTANCE TO THE BUSINESS CYCLE

Clark (1934) found that durable goods industries are more cyclical and less stable than are consumer goods industries, because expenditures for durable goods are far more sensitive to changes in income than are expenditures for services. States with a high level of dependence on durable goods manufacturing are thus expected to show a high degree of cyclical instability.

Urquhart (1981) examined the cyclical sensitivity of the fastest growing components of the service sector--transportation, communication, public utilities, wholesale and retail trade, finance, insurance, real estate, and government. In an effort to determine whether service employment is "recession-proof," Urquhart used payroll figures to compare the average annual percentage change in employment 
during periods of expansion and contraction. His findings show that during the period 1957-58, employment in the aforementioned service industries increased, even though the business cycle was in a downturn. The goods-producing sector, on the other hand, showed a sharp decline in employment during this same period. Figures for the average rate of growth show that service employment advanced an average of 2.1 percent during periods of economic contraction and 4.8 percent during periods of expansion, while employment in the goodsproducing sector declined by 8.3 percent during recession and increased by approximately 3.8 percent during the recovery period of 1959. Urquhart's findings support the argument advocating the growth of the service sector as a buffer against the severity of business downturns (Burns, 1960).

Bowers (1981) has also done considerable work on service industry resistance to business cycles, focusing on the period between 1948 and 1980. His findings show that: (1) service industry jobs, in proportion to total employment, increased during the period studied; (2) during cyclical troughs, service jobs always form a higher proportion of total employment than during the cyclical peak; and (3) the goodsproducing sector's share of total employment has steadily declined and is vulnerable to cyclical developments. He concludes that the service sector is immune to business cycles, but that the rate of growth for this sector will ultimately lessen.

The above two studies present a fair picture of the range of empirical studies that focus on service sector resistance to business cycles. Most empirical studies, however, deal with more general aspects of service sector employment. The model to be evaluated in 
the present study expresses a greater affinity with the latter category. Accordingly, these studies will receive treatment here in greater depth.

Browne (1985) compared the impact of structural change and cyclical decline on employment, finding that structural change is the more serious of the two. That manufacturing's share of total employment has declined since 1960 is a serious matter, according to Browne. The number of jobs in some industrial occupations have permanently declined, and workers employed in these occupations must look for entirely different kinds of work. The overall loss in manufacturing employment is compensated for by employment growth in the service industries.

To analyze the impact of the business downturn, the author examined the 1981-82 recession and found that it affected 9.7 percent of civilian employment. For those working in white-collar occupations, five percent of the work force was affected, as compared with 14 percent for blue-collar workers.

Many of the workers who lost their jobs during this business downturn were not to be recalled during the subsequent recovery, as had been the case during previous recoveries from recessions. Thus, the 1981-82 recession caused major structural shifts in the economy. The 1981-82 recession also differed from previous ones in its impact on industrial employment. In July of 1984, manufacturing employment was still down 630,000 jobs, or three percent, from the peak level prior to the 1981-82 recession, and down 1.2 million, or six percent, from the peak preceding the 1980 recession. Auto industry employment, which began its decline in 1979, was approximately 200,000 jobs below 
its industry high reached in 1979. Such a decline in auto industry employment to levels below its industry peak at that state of the recovery is unusual, says Browne.

Leveson (1982) observed that employment, wages, and production in American service industries have fluctuated much less than in other industries over the years. However, he stresses that stability in employment and production are not to be found in all service industries. For example, the airline industry was one of the service industries hit very hard by the 1982 recession. Nonetheless, the service sector increased by 217,000 jobs, while manufacturing employment fell by 1.3 million, between July of 1981 and April of 1982 .

Leveson's conclusion is similar to that reached by Conroy (1975), who maintains that industries paying higher wages usually contribute to a lower annual income, since the sector does not resist business cycles. Industries paying lower wages are seen as generating a higher annual income as a result of their relative stability.

\section{THE DISTRIBUTION AND GROWTH OF SERVICES}

One of the earliest of this type of empirical study was conducted by Stigler (1956). Employing regression analysis, he examined family expenditure patterns to determine how rising per capita income affected service industries between 1919 and 1941. He found that as family income increased, expenditures for food declined, and expenditures for nonfood items rose. He attributed the steady increase in service industry employment to a rise in income, although increased income also produced a reduction in certain types of service industry employment (e.g., domestic service). 
Sorrention (1970) conducted a study of employment shifts between 1950 and 1970 in ten industrialized countries. He analyzed three categories ố industry: (1) agricultural industries (forestry, hunting, fishing, etc.); (2) goods-producing industries, such as mining, manufacturing, and construction; and (3) service industries (specifically, transportation, communication, public utilities, trade, finance, public administration, private household services, and miscellaneous services). Data were drawn from the following areas: Western Europe, the U.S., Japan, Canada, and Scandinavia. He compared his data from these countries with U.S. trends in an effort to determine how widespread the shift was. Sorrention found that all countries declined significantly in agricultural employment and experienced a concurrent rise in industrial employment during the period under study. However, manufacturing's share of employment growth declined relative to that for the service sector. While the U.S. was the first to employ more than 50 percent of its work force in service industry employment, Canada, the United Kingdom, Belgium, the Netherlands, and Sweden had also surpassed the 50 percent mark by 1958.

Tulpule's 1966 study also looks at service markets. Ising regression analysis, he examined the distribution of service industries outside the central areas of London during the period 1951-61. Tulpule's study addresses two subgroups of service-industry employment--the distributive and the financial trades. He found that for every 1,000 residents, eight were employed in distributive trade jobs. Every manufacturing workplace employing 1,000 people created a demand for 25 distributive trade jobs in 1951, and every nonmanufacturing 
workplace employing 1,000 people created a demand for 195 jobs in 1951. By 1961, the corresponding figures were 11,12 and 203 , respectively. Thus coefficient changes from 1951 to 1961 suggest a definite trend toward greater numbers of service jobs, and Tulpule predicts that still higher coeficients will appear in the future.

Financial institution employment showed similar results. In 1951, for every 1,000 people employed in the distributive trades, demand was created for 160 financlal employees. By 1961, that figure had climbed to 168 . For professional services, the figures rose similarly--from a demand of six per 1,000 in 1951, to a demand of 14 per 1,000 in 1961 .

A study by Tanny (1978) undertook to explain the unprecedented shift to service industry employment, attempting to bring together the social and economic forces shaping this qualitative shift and to subject these forces to quantitative evaluation. His study further attempted to predict as well as to describe. Using Canadian data, the study was intended to show the direction that post-industrialized Western society will take in the next half-century, while limiting spccific projections to a six-year period.

Tanny's projections show continued service sector growth, ultimately to 60.9 percent of total employment. He sees a concurrent drop in manufacturing (particularly in the high-productivity sectors), to 19 percent of total employment. He predicts a decline in the labor force for people aged 14-24, because of an increasing emphasis on formal education, and for people aged 55 and over, because of earlier retirement associated with better pension benefits and greater demand for leisure time. 
Although his approach to the subject is novel, Tanny's findings are consistent with those of other researchers, notably Bell's, which envision post-industrial society in much the same way.

Lawrence and Broner (1979) conducted an analysis of the relationship between service industry growth and state industrial policy. They hypothesized that service industries grow fastest in states having an industrial policy (that is, those states employing such measures as industrial loans and/or development bonds, tax abatement plans, exemptions, rebates and advertising) that are specifically designed to attract manufacturing industries. If their hypothesis is correct, then implementation of a statewide industrial policy would facilitate development of service industry employment. In testing their hypothesis, they relied on two assumptions; first, that a state with manufacturing industries has a high per capita income and a large population, and second, that most service industries could not be relocated unless the industries they serve were also relocated. They then employed regression analysis to test their hypothesis, using the following dependent variables: TCU (transportation, communication, and utilities), TR (wholesale and retail trade), EIRE (finance, insurance, and real estate), BR (business and repair services), PRO (professional services), and PER (personal services).

They found that of the six dependent variables tested, only two-PRO and PER--appeared unaffected by statewide industrial policies, while the other four were affected significantly. Their findings demonstrate that service sector employment is enhanced considerably by a state industrial development policy.

A Kutscher and Mark study (1983) evaluates three common 
perceptions. The flrst is that the service sector consists entirely of Industries having low levels of productivity. Their findings caution against such a generalization. For example, they found that during the period $1965-80$, a 7.8 percent per year productivity growth rate for the administration of petroleum pipelines. At the other end of the spectrum, they document up to one percent annual productivity decline for eating and drinking establishments and retall food stores in the period 1973-80. Particularly rapid growth is noted in air transportation, telephone communications, and gasoline service stations.

The second perception evaluated by Kutscher and Mark is that of low capital intensity in service industries. They examined 1973 data on capital stock categorized by industry, and they again found a wide range of results. For example, transportation and utilities were found to be highly capital intensive. Further, in ranking industries according to labor intensity, they found that the service sector represented 17 of the 30 most labor-intensive industries in the entire economy.

The third and perhaps most significant perception studied by Kutscher and Mark is the notion that the employment shift from the goods-producing sector to the service sector has been the major factor in the productivity slowdown in the last 10 to 15 years. To evaluate this notion, they assembled data to measure employment for the period 1959-79 in a number of ways. They found that, regardless of the period chosen or the output measure employed, the shift had only a negligible effect on productivity.

The findings of Kutscher and Mark have been validated by a number 
of researchers, including Personick (1983), whose Monthly Labor Review job outlook projections for 1995 were based on conclusions similar to Kutscher and Mark's.

The Bureau of Labor Statistics makes a number of employment projections. For example, business service employment is expected to provide new jobs between 1982 and 1995, and its employment level is expected to grow from 3.7 million in 1982 to 6.2 million in 1995 . Professional service employment is expected to follow the same general trend, with an increase of more than 850,000 jobs during the same period. Employment in wholesale and retail trade is expected to increase from 22 million in 1982 to 28.5 million in 1995; and banking, transportation, and utilities are also expected to show at least modest growth in the years to come.

In a paper entitled The Future of the World Economy Leontief (1977) examines the long-term prospects for the service sector and investigates its interaction with various economic, technological, and social developmental programs sponsored by the United Nations. The study covers the world economy to the year 2000, and does so by considering the demographic, economic, and environmental state of the world in the years 1980,1990 , and 2000 . Leontief divides the world into 15 regions, each of which he describes in terms of 45 economic sectors. These regions, though treated separately, are related to one another on the basis of exports, imports, capital flow, air transport, and foreign interest payments. Although the study is directed mainly at manufacturing and primary production, Leontief provides several forecasts for the service sector.

Leontief's projections suggest that service industries will con- 
tinue to be the fastest growing sectors of the world economy. In the case of developing countries, employment in the service sector is expected to grow at a level parallel to that for manufacturing. However, service sector growth with regard to GNP is expected to be somewhat lower than for manufacturing. The study also makes the observation that the creation of a service industry infrastructure is essential to the development of the manufacturing economy.

In general, the study projects changes in the structure of international trade, indicating that developed market economies will increase their share of world service exports, while the share for developing nations will decline. As for the import of services, the report suggests that the developing nations will increase their share of service imports, while the share for industrialized nations will decrease significantly. Further, the importance of the international trade of services will increase faster in the North than in the South.

Shelp (1981) readdressed Leontief's U.N.-sponsored research. because it assumed the service industries to be static rather than dynamic. Service industries represent a dynamic sector, according to Shelp, as is evidenced in the emergence of new kinds, forms, and sources of service sector development. This sort of dynamic trend is seen clearly in the entry of nonservice companies (e.g., manufacturing firms) into the service arena, which is frequently accomplished by acquisition.

The second of the dynamic trends is seen in the expanding relationship between nonservice industries and various managerial, professional, consulting, and rental services. Further, health care systems, though currently operating primarily in national markets, 
will likely expand internationally, since there is a growing demand for such services, especially in developing nations.

The third of the dynamic trends in the service sector is its expansion internationally. Franchising is one example of this, and it appears that, in the future, this kind of activity will grow. Exemplary among franchising service industries are hotels, auto leasing firms, and fast food restaurants, all of which are expected to expand their international operations in the future. Shelp suggests that, in the future, service industries will exhibit far more dynamic change than we have seen in the past.

Although these dynamic changes in the service economy are taking place in developed nations, they are not, according to shelp, an extension of government policy. In fact, if anything, the contrary is true. The United States provides a good example of a developed nation whose national policy shows a blas in favor of manufacturing. For example, during periods of high unemployment, government policy dictates a modification of the investment tax credit in order to accelerate depreciation as an incentive for investment and, hence, job creation. This policy does not address the needs of service industries, since the service industry is, for the most part, labor intensive rather than capital intensive.

During periods of inflation, on the other hand, government policy tends to concern itself with the cost of primary commodities and large wage settlements, both of which, while affecting the service sector indirectly, are directed primarily at manufacturing and agriculture. Furthermore, government economic indicators of consumption, growth, and inflation emphasize nonservice industries. Inconsistency exists 
between the government's admission that, on the one hand, the United States is a service economy, and, on the other, we implicit assumption in remedial policy that job creation, economic growth, and price stability must originate in nonservice sectors of the econony. Shelp concludes that, for the most part, the failures of policy makers are due to economic programs which emphasize manufaturing at both the micro- and macroeconomic levels in the national and international economy.

Fuchs (1968) examined the three primary determinants of the shift of employment toward the service sector. The first of these is an increasingly rapid growth of final demand for services, which can be explained in terms of spending trends and levels of income. Many studies suggest that, as income increases, the demand for goods tends to $\mathrm{r}$ ise less rapidly than the demand for services. Thus, the proportion of services in the economy will also rise. However, after analyzing cross-sectional buying patterns and trends in output overtime. Fuchs shows that the growth of income and the consequent shift in demand was not a major cause for the relative growth of service employment. Measuring the dollars of constant purchasing power, he saw the service sector's share of output was the same in 1965 as it was in 1929. Measured in current dollars, the figure grew from 47 to 50 percent.

The second determinant is the relative increase in the intermediate demand for services. Fuchs explains that this is due to the growth of the intermediate demand for services by goods-producing industries. Most manufacturing firms, as they expand and specialize, tend to contract out more of their work to service firms. To investi- 
gate this, Fuchs compared input-output tables for the years 1947 and 1958 and found that there has been an increase in the practice of contracting work out from manufacturing to service firms. However, the impact of this practice as a major determinant of service sector employment growth is not particularly significant. Its contribution to service employment represents only 10 percent of the total employment shift.

Fuchs analyzed the productivity of the service industries in the United States between 1939 and 1963, examining the differentials in output and productivity across 17 service industries. of these, 16 showed positive rates of change in real output per man. It was clear that productivity rose in the service sector, although less quickly than in manufacturing. Additionally, the rate of increase in productivity in manufacturing was not as high as for the goods-producing sector as a whole.

Jonscher (1983) examined the productivity revolution in the service sector in recent years. Investment in services throughout the United States has been growing, especially in fields utilizing technological equipment such as computers, word processors, and telecommunications systems. This deployment of new technology has revolutionized the service sector as firms cut costs by increasing worker productivity. These changes are expected to increase productivity's annual growth rate to at least 2.5 percent during this decade, approaching the robust three percent growth rate seen in the 1950 s and 1960 s, and outstripping the sluggish 1970 s growth rate of less than one percent. This growth is based on technological investments made by service industries, which increased by about $\$ 47$ billion in 1982 , a 
145 percent increase over 1975. The industries within the service sector that are investing most heavily in new technology are transportation, accounting, legal and management consulting firms, wholesale and retail stores, medical facilities, hotel chains, and administrative, design, and maintenance services.

During this same period of rising productivity that is attributable to the employment of new technology, employment levels rose by 25 percent, from 46.1 million to 57.6 million workers. 


\section{CHAPTER V}

\section{THE DISTRIBUTION OF SERVICES IN}

THE REGIONAL ECONOMY

Gottman (1983), in a discussion of the geography of services, refers to what he calls a renaissance in the cities, pointing not to design features or urban renewal, but instead to a much deeper transformation. One of the changes he sees is the emerging predominance of service industries. The use of new technology, urbanization, and the expansion of long-distance trade all foster the growth of services such as education, research, advertising, information, and distribution. In this sense, a society's way of life depends on the performance of a wide range of services. However, a close examination of the various service industries makes it clear that there exists in them a great many spatial variations relative to their functions. Linking services to local trends and then finding the cause of the linkages should both improve our understanding of human geography and provide insights into the socioeconomic functioning of society. This should, in turn, help forecast both future land use trends and the distribution of populations. At present, geographers address themselves to data on the relocation of offices, retail trade outlets, and the like, since these indicate geographical trends related to service industries. Generally, most present literature on the distribution of services concentrates on spatial analysis, focusing on agglomerations existing in specific locations, but does not address 
the breaking down of agglomerations in the course of decentralization. Decentralization occurs when a business changes the location of its main office and its proximate service establishments. However, some cities are not randomly dispersed spatially, and as a result, some services are growing more quickly than others. This is the matter at the heart of Gottman's work, and he summarizes the central proposition of his work as follows:

The concept of the hosting environment of quaternary services should be today an important aspect of human geography, of economic planning and regional development. Office location has been helpful and an interesting chapter of geography. I do not want to underestimate its contribution. But it now seems high time to expand these concerns further and into the much more exciting field of the geography services.

In order to examine the transfer of information in large metropolitan areas, Cohen (1979) classified corporate head offices and a group of business services (including finance, law, accounting, and management consulting), labeling the latter as advanced corporate services (ACS). He found these institutions to be very important for long-term planning. The spatial location of economic activities is usually assumed to be determined by the benefits derived from agglomeration and the size of the economy. Cohen investigated particulariy closely the function of market changes in the advanced corporate services.

His findings seem to show that corporations and advanced corporate services are the two most important factors shaping the development of the cities. But market changes affect advanced corporate services by changing the types of activities that are centralized in many cities. As a result, many activities no longer need to be located at the centralized headquarters, thus becoming decentralized 
functions.

Cohen found that several shifts have occurred over the past 18 years with regard to centers of corporate headquarters. New York has lost approximately one-third of its head offices, a trend similar to that in other major cities. Some cities, however, have experienced gains--Los Angeles, for example--while others have experienced losses due to market shifts. Suburban areas, on the other hand, have been attracting head of fices since the 1960s, a trend that is continuing. Both suburban and branch of fices disperse regionally, yet retain close ties with their centrally located head of $f$ ices. The lines of communication between branches and their head offices are facilitated by the development of advanced communications, computers, and electronic technology that permit the rapid transmission of information.

Corey (1982) examined the emergence of new metropolitan areas. Many large metropolitan areas in the developed countrles are currently experiencing spatial changes in addition to experiencing shifts in employment and occupational structures. Currently, job opportunities are expanding in areas requiring specialized skills; however, these jobs are to be found more readily in the service sector than in the goods-producing sector.

In many western industrialized countries, the core urban population has been declining for many decades while suburban areas have been growing. This is due largely to the out-migration of manufacturing, wholesale trade, and hence employment. This has been followed by the development of transportation and communication systems that have further reduced urban population density.

Among the forces behind the migration of populations from the 
cities to the suburbs is the suburbanization of of ice-based activities, accounted for mainly by service industries in the course of decentralization. Some European nations have encouraged the decentralization of office and manufacturing activities, hastening the migration from central cities to the provinces, as a way of encouraging more widespread growth and development. Another force partly responsible for decentralization is the negative pressure of major city congestion, pollution, and crime, which make cities less desirable environments.

Daniels (1983) attempts to explain the spatial and organizational variations in the behavior of business service offices in eight British provincial cities. Daniels analyzes the kinds of changes that business service establishments have been experiencing between 1970 and 1980. The target sample consisted of approximately 1200 establishments, and Daniels structured the sample in a way which adequately represented the structure of the service sectors in each urban area. The sample was categorized as follows: (1) establishments in the city center, (2) those in areas with between eleven and twenty establishments, and (3) those in areas with more than twenty establishments. He found changes which could have affected individual of fice establishments between 1978 and 1980 . These, he said, are connected with location, involvement in merger or acquisition activity, a change of head-office location, and changes in employment. A total of 69 office establishments did not experience any changes, and the majority 130 , only reported one change. However, he stated that about 80 percent involved some kind of locational changes. Employment growth was found to result from expansion, either from spontaneous 
business growth or from expansion of market share.

Polese (1982) examined the service industries on a regional and interregional level in the Canadian provinces. He surveyed business establishments, including 130 retail, 65 wholesale, and 86 construction business service establishments. Based on these data, he stated that the propensity to use services is a positive function of city size. Further, the function of size is proportional in that, as a firm's operations grow larger, it relies more heavily on services. This pattern is consistent with business service industry patterns in the United States and Canada. Examining each sector separately. Polese found that trucking, which is market oriented, is important to both intra- and interfirm demand structure, accounting for 25.8 percent of total demand. Engineering services generate more interfirm than intrafirm demand. Financial business services account for 68.1 percent of intrafira demand, while they account for only 31.4 percent of interfirm demand. On the basis of his findings, Polese points out that the theory of service flows should be tied to theories of head office locations.

A study by Miernyk (1977) on the changing structure of the South's economy discusses several interesting points. His primary research involved measuring the structural changes in the South's economy between the years 1940 and 1975 . His focus was ascertaining whether the Clark-Fisher hypothesis is applicable to these specific structural changes.

In 1940, the South's economy was dominated by agricultural employment, and it also exhibited other major differences from the rest of the nation. In 1940, agricultural employment in the South was 73 
percent higher than the national average. The number of workers engaged in the production of basic energy was about one-third higher than the national average. Manufacturing in the South was at only two-thirds the level of the nation as a whole. These discrepancies are also reflected in figures for the service sector, including communications, utilities, finance, insurance, and real estate.

By 1975, however, the proportionate employment discrepancies between the South and the nation as a whole were narrower and, in ma:ay cases, had disappeared altogether. Agricultural employment in the South had reached a level equal to the national average, and manufacturing employment grew to a level less than 10 percent below the national average.

Surprisingly, the service industries, including transportation, communication, utilities, and government, have risen to levels above the national average. From a regional viewpoint, the South has become more industrialized and urbanized, and its market base has expanded. Manufacturing was attracted by the region's raw materials, nonunionized labor force, and low energy costs.

A high per capita income is necessary for the expansion of service industries. By 1975, it was observed that the structural differences between the South and the rest of the nation had narrowed. While per capita income in the South in 1940 was lower than in the rest of the nation, by 1975 , the gap had narrowed. This increase in per capita income is related to overall structural changes in the South. The Clark-Fisher hypothesis, which states that employment will shift from secondary to service industries as per capita income rises, is correct, given these events, according to Miernyk. This conclusion 
is consistent with early stages of development; technological change not only tends to increase per capita income, but in the process creates surplus labor in the agricultural and manufacturing sectors. The rise in per capita income, coupled with the surplus labor force, induces growth in service sector employment, in most cases regardless of technological innovations.

Other authors also document the structural changes in the South. Kahley and Tapp (1983) examined the recent shifts in the Georgia economy, describing pitfalls and opportunities created by structural changes in the economy. Before analyzing the state's economic transformation, they addressed changes in the structure of the economy on the national level.

The first of these structural changes is that, al though the United States is still consuming its domestic production, the export of U.S. merchandise has declined substantially. To compensate for the decline in merchandising exports, the U.S. has increased its exports of services, which is an indication of its shift away from a reliance on the traditional export base of manufacturing.

The second of these structural shifts is the recent increase in the use of automation in manufacturing in the United States, a trend that promotes the more efficient production of goods regardless of the manufacturing location.

These national structural economic trends are examined in order to better understand the impact of changes in the Southern economy. He looked at the sfracific cases of Florida and Georgia for purposes of comparison.

Since 1960, the Florida economy has shifted from the manufac- 
turing to the service sector. Trade and services sector increased their share of the state's total employment from 44 percent in 1960 to 51 percent in 1983. The service sector such as personal, social and miscellaneous grew from 16.6 percent in 1960 to 24.3 percent in 1983 . The expansion in service sectors is largely preceded by a similar trend in the national economy. Meanwhile, manufacturing's share of employment fell from 16 percent in 1960 to just 12 percent in 1983. A similar trend in the nationwide drop from 31 percent to 21 percent over that period.

In Georgia, the service sector was expanding rapidly. The percentage of employment in such service industries as hotels, personal services, and business and repair services was growing even more quickly than the national average. It was also found that growth in the state's service industries has led to significant prosperity over the past decade. Georgia's pace of economic growth continues to exceed the national average.

The structural changes sweeping the United States are clearly illustrated by their effects on the Southern states. Strong in services and the new high-technology industries, Georgia and Florida have benefitted from the structural changes in the economy. The authors conclude that the current transformation of the U.S. economy presents both problems and opportunities. States and communities that recognize these structural changes and adjust to them will better realize their full potential for economic growth.

Several major theories of the importance of the service sector in the United States have emerged in recent years. These theories explain the general pattern of service sector employment growth as 
manufacturing productivity has increased (Fuchs. 1968). Patterns for business services were recently examined by Nayelle (1983). In his study of business service growth in the lnited States, Noyelle found that the industry has performed extraordinarily well. The major forces behind the growth of business service industries include a market that has been steadily expanding since the postwar period and the growth of the U.S. population from 152 million in 1950 to 222 million in 1980. Further, there has been a corresponding rise in the v.S. labor force, from 26 million to 102 million during the same period, as well as a rise in disposable income, which grew from $\$ 362$ billion in 1950 to over $\$ 1,000$ billion in 1980 .

Another force behind the growth of business service industries has been the opening of new market channels facilitated by advances in transportation and communications (Toffler, 1980). Moreover, the expansion of transportation technology connects states and regions. availing manufacturers and populations of relocation opportunities.

Another influence Toffler describes is the rise of the large corporation in America, a trend that has been taking place in the postwar period. Modern corporate operations extend production and distribution throughout a region, administering numerous branches more efficiently than before, due in part to technological advances that permit large-scale operations. These technological developments, as well as regional market expansion, make possible multi-regional corporations and multiple-product operations administered from one central office. This type of corporation is fundamental to the development of urban and regional economies.

Bearse (1978) identifies an intraregional diffusion of business 
service industries in the United states. His view is that business services are innovative, thereby influencing the diffusion process. The study analyzes 73 counties surrounding New York City, and he cites several factors influencing diffusion, including the rate and conditions of new enterprise entries into the market.

The first factor to which he attributes a diffusing influence is urban agglomeration, believed to affect the location of service sector businesses. The second factor is the matter of the threshold level, i.e.. that the market size necessary for a business-service industry to succeed in a given area is much higher than that required for a personal service industry. The third factor is the sub-regional economic structures that influence business service industries.

On the basis of the above factors, Bearse asserts that his findings of fer strong support for the existence of an innovation-diffusion process related to the spatially hierarchical form of the region's economy. Bearse concludes that spatial diffusion of business services is related to the industrial structure of the regional economy. In turn, the spatial and industrial organization of business service industries will influence the innovation, diffusion, and the evolution of other activities in the region's economy.

Along these lines, The Organization for Economic Cooperation and Development (1978) discusses the implications of the trend toward relative expansion of the service industries for regional policy, particularly in the matter of location factors. The discussion addresses trends in both primary and manufacturing industries since the time of the United Kingdom's industrial revolution. Further, the study discusses historical trends and the current rapid economic 
growth of the service industries, as well as their links with the localities they serve.

In earlier periods the service sector was concentrated in capital cities, where populations are dense, and from there disbursed their services to other cities. But the growth of these service industries and the massive number of educated graduates seeking employment changed the service industries from local service providers to metropolitan and international service providers. A factor even more relevant to the dispersal of service industries has been the development of new and sophisticated methods of communication, which have enabled service industries to relocate to wherever they choose. Advanced communication will increase the decentralization of the service sector even more, increasing its geographical independence. However, the regional and international dispersal of service industries does not necessarily mean their movement will be toward manufacturing centers. Instead, they will be inclined to move to localities where their clientele may best be served.

An even more important factor contributing to decentralization has been the migration of the population to areas outside major cities. This migration has tended to draw the service industries out in their wake. For example, it was found that, due to the expansion and development of department store chains, wholesale and retail trade spread out regionally. Financial institutions also have of fices regionally located and administered from a central office. The location of social services, including education and medical services, depends on the distribution of the population served. The study concludes that the growth of service sector employment will continue, and that 
government action is required in order to develop physical and social infrastructures on a regional basis.

Pascal and Gurwitz (1983) present a sector-by-sector analysis of metropolitan economic development. While it is sometimes believed that service jobs do not provide upward mobility, the authors found no support for this contention. Manufacturing, for example, of fers fewer career opportunities than some service industries. In fact, depending on the location of the service industries, service sector jobs appear to be more highly valued than jobs in some manufacturing industries. An important finding is that, compared to manufacturing, the service industries, being insensitive to business cycle, provide a boost to local economies in most cases.

Finally, based on an analysis of employment in the years 1970-77 in 243 SMSA's, Pascal and Gurwitz recommend that policy planners assess the potential effectiveness of economic development, considering separate industrial strategies for different metropolitan areas, since the differences between metropolitan areas may be as important as the differences between industries.

The Bureau of Labor Statistics (1985) discusses service industry job growth in the United States, citing reports showing that jobs are currently to be found in the service sector in such industries as transportation, trade, finance, health, education, and government. In fact, the service industries are absorbing twice the number of employees as are manufacturing, mining, and agriculture combined. From the 1960 s through the $1980 \mathrm{~s}$, almost all job growth in the United States was in the service sector. In 1982 alone, the three service industries of health, retail trade, and miscellaneous business ser- 
vices accounted for almost one-fourth of all new jobs. If this trend continues, the Bureau predicts, these service Industries will generate one-third of all new jobs between 1982 and 1995. Analyzing the service subgroups separately, it was seen that the health industry alone employed seven million Americans, providing numerous entry-level positions for new graduates. Retail trade provided opportunities for several million job seekers. In 1984, retail trade employed 17 million workers, the largest in the service sector, and this figure is expected to continue growing. Miscellaneous business services accounted for nearly one out of twenty new jobs between 1974 and 1984 . This growth indicates that the industry is growing fast--nearly four times faster than the economy as a whole--and is expected to grow even faster in the future.

Moskal (1985) examined recent developments in the computer industry, focusing on the areas of data processing, programming, and software development, all of which are expanding. The business services are an area of the service sector that took advantage of the current technological advances in computers and, as a result of its growth, says the Bureau of Labor Statistics, it was the fastest job creation industry in 1984 .

Moskal found that, during the same period that $1,087,000$ jobs were created in business services, manufacturing lost 642,000 jobs. Unlike the negative impact technological development had on agriculture and manufacturing, the recent technological boom is now creating jobs in many professions. In office work, for example, automation has spurred the need for operators and other electronic office equipment professionals. At the same time, supply firms are setting up programs 
for training office personnel in the use of sophisticated equipment. In fact, according to projections by the Bureau of Labor Statistics, the miscellaneous service industries will continue to be the fastest growing segment of the service sector and are expected to employ 31 million workers by 1995 . 


\section{CHAPTER VI}

\section{SPATIAL ANALYSIS OF THE SERVICE INDUSTRIES}

Daniels (1982) addresses the issues of service industry growth and the spatial distribution of that growth in England. Daniels attempts to identify inconsistencies in the distribution of the sites of service industry growth. He asserts that there are consequences of the patterns of development for regions as well as for individual consumers of services. Classifying the service industries by function, he analyzed the location preferences for services of final demand. He begins by dividing the service sector into: (1) consumer services, which provide services directly to consumers; and (2) producer services, which provide services consumed by other industries. Examples of the latter would be wholesale trade, business and planning consultants, and public relations firms.

Using the above classifications, Daniels found that service industry locations are a function of demand. Further, this demand has tended to increase, creating an increasingly advanced service sector employing a growing portion of the labor force. Thus, the success or failure of a particular service industry is based on the presence of a suitable market in its region. In other words, demand controls supply. Also common to all service industry location preferences is the requirement that location ensure the client easy access to the service. Accordingly, most service industries--among them finance, 
banking, professional services, and public administration--tend to concentrate in urban areas. Daniels concludes that current trends in service industry growth and site location can be expected to continue.

The United States is not the only country to be characterized in recent years as a service economy. As previously noted, Western European countries, too, have experienced an expansion of the service sector. By 1977, for example, members of the European Economic Community (EEC) employed 52 percent of their labor force in service industries. Thus EEC countries may be defined as having service economies.

Growth has been constant in service industries in the EEC countries, and by the 1970 s, the service sector had the largest share of total employment, having experienced especially rapid growth in producer services, such as insurance, banking, and finance. Growth in the area of business services has been particularly strong, and growth in the distributive services in EEC countries has also been strong though slightly less than business services. Social services have also grown very quickly, especially in the areas of education and health and, in some cases, its growth has been greater than that of business services. As of 1979, total service sector employment was still growing, despite the impact of cyclical variations in the economy.

Grubb (1982) examined the migration from the cities to the suburbs of both population and jobs during the decade 1960-70. On the basis of his data, he developed an econometric model of suburbanization in the largest SMSAs. In Grubb's model, one set of equations describes the location of the population, and another set 
explains the location of employment. He tested the hypothesis that suburbanization is a self-reinforcing phenomenon, where in the early stages of mobility and migration create the conditions for its ongoing development. The relationship between the population and service firms constitutes a self-reinforcing factor. If the population moves to the suburbs, says Grubb, then firms may also find it to their advantage to move to the suburbs in order to be near both their customers and their labor force. Conversely, when firms begin to suburbanize--frequently in response to both the availability and affordability of land--this may induce populations to relocate closer to these new employment and consumer opportunities.

Grubb's findings show that the location of service employment tends to follow the population. Similarly, retail employment follows the suburbanization of the high-income population. In turn, families with moderate and high incomes tend to follow the location of retail employment.

Gober and Behrs (1982) investigated the differences between central cities and the suburbs using demographic, structural and economic variables. Their study focused on the question of whether or not the cities and suburbs are, in fact, empirically different.

The authors subjected their specific variables to discriminate analysis in order to assess the differences between the central cities and the suburbs. And also to discover how well these variables discriminate between urban and suburban environments. In their results, the minority variables indicated a proportionally larger presence of minority residents in central cities than in suburbs. The economic variables substantiated that low-income residents are unable 
to move outward toward the suburbs. The employment variables, designed to measure the extent to which one can discriminate between central cities and suburbs on the basis of employment structures. indicated that cities and suburbs do differ in manufacturing and retail trade employment.

The service industries, however, do not show evidence of discrimination between the central cities and the suburbs, due largely to the fact that service employment is greatly centralized in urban areas. An exception to this pattern is to be found in the "Sunbelt" states, where metropolitan areas are largely decentralized, lacking cohesive core areas. The suburbs maintain levels of service employment that are sufficient to compete with central cities where extensive decentralization of employment has occurred. Thus, in these areas the suburbs interact with the central cities on a more equitable basis in the matter of providing both employment and labor.

Steinner (1982) developed a time-series method of analysis to determine the direction of the casual relationship between interurban employment and residential location. His findings indicate that jobs follow populations. Populations do not follow manufacturing and services, but they do follow retail trade. Additionally, the tendency to follow populations is seen more prominently in services than in manufacturing.

Kellerman and Krakover (1986) conducted a multi-sectoral, spatiotemporal analysis of urban growth in the Philadelphia metropolitan area. Their focus was to identify different spatio-temporal paths for both residential and economic sectors, the latter of which includes manufacturing, wholesale trade, FIRE (finance, insurance, real 
estate), retail trade, and services. The analysis was intended to ascertain the rate at which decentralization occurred in the various economic sectors, that is, the rate at which sectors in the outer geographical areas were outgrowing, either in relative or absolute terms, sectors in the central city.

The findings show that the fastest growing sector is the service sector, followed by wholesale trade, FIRE, retail trade, population. and manufacturing. Spatially, these findings indicate an economy undergoing changes away from manufacturing and toward the tertiary and quaternary sectors. This growth indicates that the trend is coupled with complex spatial changes. Population attained the highest outlying growth peak, but the faster-growing economic sectors presented more complex trends. FIRE showed a secondary spatial growth peak located beyond the boundaries of the urban field, while retail trade double-peaked within the boundaries of the Philadelphia urban field.

Services and wholesale trade are shown to be suburban in their growth trends, and the latter shows further indications of peripheral growth. Manufacturing, on the other hand, is undergoing a general decline, especially in the inner and peripheral areas. The findings also show that services, wholesale trade, and FIRE may be identified as trailing sectors. Nonetheless, these three continue their suburban growth, while retail trade, as a leading sector, is at a state where it is developing peaks of growth in the outer areas. Since population plays the role of a leading factor, its spread to the outer areas indicates further growth in the other sectors as well.

Gershuny and Miles (1983) conducted a detailed examination of the 
service sector economy and the evolution of demand for services. In order to study the subject, they devised two methods for classifying service industries. The first divides the service sector into intermediate and final services. Intermediate services are considered to be equivalent to producer services, and their growth is a consequence of the search for efficient productinn through the division of labor. For example, instead of employing specialized service labor, firms subcontract service tasks to specialized service agencies. Doing so provides the advantages of scale and specialization. Examples of intermediate services include design, advertising, marketing, and technical consulting, as well as other, less skilled intermediate services, such as cleaning, catering, and security. In addition to providing their services to segments of the national economy, these intermediate producer service firms also export their expertise to newly industrialized but otherwise underdeveloped nations.

The second method of classification divides the service sector into market and nonmarket services. Consequently, by combination there exist two forms of final services, market and nonmarket, and two forms of intermedlate services, again market and nonmarket.

Market final services are those sold directly to their ultimate, or final, consumer. The demand for these services is based on income elasticity, which means that the higher the income, the greater the demand for these market final services. On the other hand, the demand for final market services is also price elastic, which means that the more costly the service, the lower the demand.

Nonmarket final services, on the other hand, include services 
provided for largely out of tax revenues; these include social services and many other state-funded programs. Except for U.S. health services, the industrialized countries are not significantly affected by the market price for these nonmarket final services.

After first analyzing the demand for both intermediate and final services, and then analyzing demand for market and nonmarket final services, Gershuny and Miles tested their theory by applying it to data assembled in EEC countries. They found that producer services employment rose in 1970 , which is consistent with the continuing increases in market intermediate services. Britain, France, Germany, and Italy showed very similar growth trends during the 1920s, which then leveled off in the 1930 s.

Goods transport and final market services were also thought to affect the second service distributive segment of the economy (transportation, communications, wholesale and retail trade). For these industries, Germany and Italy showed a general rise in their proportion of employment; France remained constant, while England and Wales showed a decline. However, in all four countries, wholesale and retail trade showed a considerable increase in employment.

The data for final market services, i.e., personal services, showed a decline in England, Wales and Germany, which begins in the 1930 s and continues. However, this segment has continued to rise in France and Italy. In terms of employment, though, the personal services in England have been rising since the 1970s. These data led Gershuny and Miles to conclude that the service industries' previous employment patterns correspond fairly well to what they had theorized. 


\section{CHAPTER VII}

\section{THE GROWTH THEORY AND DETERMINANTS}

IN THE SERVICE SECTOR

Given the present state of the industrial economy in the United States, the accelerated growth and rapid development of the service sector assumes great importance in the national economy. The service sector may thus be thought of as an independent branch of the U.S. economy, distinct from other sectors from the points of view both of employment and material production.

This stage of the economy was first identified by Fisher (1930), and later by Clark (1940), both of whom articulated a sequential path of economic development through which, they maintained. all societies would pass in the course of economic development. Their theory holds that, over time, increases in per capita income induce employment to move, first of all, from the primary to the secondary industries, and second, from the secondary industries to a service-oriented economy.

In the Fisher-clark theory, the crucial variable is change in per capita income. The theory postulates that when per capita income rises, the demand for services rises more rapidly than does the demand for goods. Using per capita income as a variable was also suggested by Casette and Jeffrey (1970) as the cause for the shift in employment toward the service industries. Both demonstrated that the growth in disposable income maintains a close relationship with the growth of 
services. Both median family income and percentage change in median family income are positively related to the elasticity of service employment.

Stigler (1956) used regression analysis in order to determine the impact of rising income on the growth of service industries. His results show that, as family income rises, expenditures for food decrease and expenditures for services increase. Along similar lines, Kindleberger (1958) asserts that service industry growth is related to rising demand for services on the part of both intermediate and final consumers. This increased demand creates a further influence on the growth of the service sector.

Per capita income's effect on agriculture, manufacturing, and the service economy was examined by Beam (1946). Analyzing historical data, Beam demonstrated that per capita income is the focal factor in the shift of employment from agriculture to manufacturing and then on to the service sector. In addition, he found that shifts from an agricultural to a manufacturing economy, and then to a service economy, results in subsequent growth in per capita income.

Fusfeld (1968) tested the population variable, long considered a major factor in the growth of employment in the service sector. His findings indicate that changes in service industry employment are explained by changes in population. A paper for the Organization for Economic Cooperation and Development (1978) discusses the dispersal of service industries from central to suburban locations as an outgrowth of both the development of advanced communications systems and the outmigration of the population away from city cores. Gottman (1983) emphasizes that urbanization, technological development, and the 
expansion of long-distance trade also foster the growth of the service Industries.

National demographic and income shifts also increase the size of the market for services (Stanback, 1979). Due to the labor-saving benefits of modern household appliances, women have lately been able to work outside the home (Gruenstein and Guerra, 1981). Services such as food preparation and child care that were once provided by family members are increasingly being purchased from outside service industry sources.

Lindner (1970) has restated the theory of consumer behavior in such a way as to make consumption subject not only to the constraints of income (the budget constraint), but also to the constraint of time. Thus, consumers substitute household services for outside services. Additionally, increased leisure time brings with it a greater demand for leisure-related services. Thus, demand for services increases in two ways: (1) consumers purchase services when they purchase goods, and (2) consumers purchase services at a later time for the maintenance of old goods.

Stanback (1979), and Hooper and Bourne (1983) stress that urbanization is the major determinant in the growth of service industries. The urbanization of many cities, bringing with it a concentration of services (producers, corporate headquarters, a host of consumer services, specialty stores, and other services), leads to an agglomeration of people and jobs. The service industries operate in urban areas in close proximity to one another, sharing the large regional, national, and even international markets. Thus, the growth of service employment in urban areas has accelerated as employment in 
manufacturing has fallen off.

Fuchs (1980) found that growth in service employment was due largely to the fact that labor productivity growth rates are substantially higher in agriculture and manufacturing than in services. Thus, the shift in labor from manufacturing (higher productivity) to services (lower productivity) is similar to the earlier shift of labor from agriculture to manufacturing.

Erickson (1983) analyzed the spatial and sectoral decentralization of the service sector and observed that "the differential growth rates of the sectors provide evidence of a distinctive staging of suburban employment composition where an initial manufacturing concentration is diluted by retail employment and followed. later in time by a significant increase in wholesale trade and service jobs." (p.106). Steinner (1982) conducted a study of the suburbanization of service industries, examining the multisectoral ordering of decentralization by dividing the sectors of 46 SMSAs by size. Steinner observes that his findings "clearly support the position that jobs follow people since four employment sectors are found to follow population." (p.412)

A recent study by Kellerman and Krakover (1985) examining decentralization and growth of service industries by using metropolitan spatial analysis provides a reflection of current structural analytical views of the economy. The primary factors influencing the sequencing of decentralization are accessibility, technological innovations, agglomeration, and product cycles. The various sectors are also affected by differing economic conditions and levels of metropolitan development. 
While the general view of service sector growth is useful--indeed essential--to an understanding of general employment trends in service industries, it does little to help forecasters accurately identify patterns of disparity among states and regions (and countries) regarding the matters of income, demographic characteristics, levels of industrialization, and degrees of urbanization--all of which arise in response to differences in regional structures. These differences, while perhaps not of great enough magnitude to affect the national picture, nonetheless frequently and significantly affect the states or regions in which they occur.

The aggregate theory, which identifies the factors that contribute to the growth of employment in the service industries, does not identify the economic components of the weaker, poorer, or more disadvantaged regions (neither absolutely nor relative to the components of more favored regions). Economic and social change interact, each affecting and being affected by the other. These forces influence the size of the various income and occupational groups and the pressures of effective demand on the goods and services of a region.

Williams (1965) dealt extensively with these ideas, his work attempting to generalize about regional disparities over time for a number of countries. His work, along with previous studies by Myerdal (1957) and Hirschman (1958), focus attention on a very important idea: that national economic growth may provide only a necessary--not a sufficient--condition for ensuring dispersion of development across all substantial regions.

others have expanded specific aspects of this modification to the 
macroeconomic theory of growth. For example, Isard (1969) recognized the linkage between spatial decentralization of decision making and the efficient allocation of industries and other economic activities among regions. Based on the specific information on given regions, he found that efficient allocation of resources for social and economic development is a function of the degree of spatial decentralization of decision making.

The macroeconomic theory of service industries, developed prior to 1933, has provided a sound means for assessing developmental patterns of the general economy. Increasingly, however, economists are coming to realize that macroeconomic theory is most useful today as a means of obtaining a very broad overview of selected national phenomena, and that it should not be used in the determination of regional policy. As Baumal states:

The aggregation of the several variables which are gathered from several regions usually deny it [macroeconomic theory] the specification and the rigor that are provided by microeconomic analysis at its best. (1968, p.2)

\section{SUMMARY}

The determinant variables, which are critical to the growth of service industries for achieving generally high levels of economic growth, have been treated in the above discussion. However, since the service industries are diverse, each predictive variable has a different impact on each service industry. This is because each industry has its own occupational pattern which is subject to frequent changes in the years ahead, just as in years past. Employment growth in the service industries has never been evenly distributed. There 
has always been a great deal of variation in the growth of service industries, so that certain determinant variables can explain one particular service industry much more effectively than another. However, taken collectively, determinant varlables such as population, income, and industrialization have been indicated to significantly affect the growth of the service economy. The variables in this chapter will also be used to describe the conceptual development of the theory in the next chapter. 


\section{CHAPTER VIII}

\section{CONCEPTUAL DEVLOPMENT OF THE METHODOLOGY}

This research details the disaggregation of growth in service employment, both by individual service industry and by region. Doing this adds a spatial dimension to the analysis of the individual segments of the service sector and adds texture to the nore general treatment of the evolution of service industry employment and its relation to regional growth.

During the period when urban devlopment was agglomerated, that is, when manufacturing and the population were concentrated in urban core areas, the service industries were also concentrated in the urban core. The market for services first appeared in those urban areas where there existed both an affluent population and interfirm demand for services. Distributive, business, social, and personal services concentrated in the core area and operated there successfully with little or no concern for competition from the S.MSA and non-S.MSAadjacent markets. Thus, the urban core locations were dominant market areas for the service industries, where consumers from adjacent and even nonadjacent areas would commute to consume services. In a sense, the urban core had a monopoly on the service economy, and it exported its services from there to the surrounding regions.

The theory of the service industries provides a highly generalized picture of the sequence of structural changes occurring in 
the economy in the course of industrialization. Industrialization brings with it urbanization, transportation, communications, and sophisticated production techniques, and invariably created many small to medium-sized cities in both metropolitan and nonmetropolitan regions. Regarding this point, Carlino (1982) found that, between 1970 and 1980, the population increased faster in nonmetropolitan, nonadjacent counties than in metropolitan ones. From 1970 to 1980. the population in nonmetropolitan counties grew by about 16 percent, while the overall U.S. metropolitan growth rate was only nine percent (Morrill, 1982).

The development of advanced communications, various modes of transportation, low-cost land, and rising wages combined to influence manufacturers to decentralize their operations and move outward from the core areas (McCarthy and Morrison, 1977). This outward migration of the population, income, and manufacturing employment stimulated the development of marketing centers outside the urban core. Given this "pull effect," it is assumed here that the service industries are also attracted outward relative to the threshold level in SMSA, non-SMSA, and nonadjacent counties. Because the service industries are largely market oriented, they expand their markets by opening branch outlets outside the urban areas and provide services similar to those available in the urban core.

In addition to the effects of the population and manufacturing on services consumption, another important influence on demand in several segments of the service sector is the population's shifting age structure. of particular significance is the relative increase in the segment of the population over 65 years of age. This group is less 
interested in traveling long distances to consume services; rather, they prefer to consume services closer to their area of residence. This induces service industries catering to that age group to decentralize, migrating toward their clientele.

As higher income groups migrate toward the urban fringe and nonSMSA areas, service industries also expand in that direction. This pattern is another indication of decentralization in a great many service industries. Since income is a measure of the relative economic positions of the core, SMSA, non-SMSA-adjacent, and non-SMSAnonadjacent counties, it also measures the relative growth of the service sector over time. The income level of the different regions varies with time, and its impact on the consumption of services is assumed to vary as well.

Thus, in view of the heterogeneous nature of the service sector, the regional growth of the different service industries is variable, largely because the structures of core, SMSA, non-SMSA, and non-SMSAnonadjacent economies in general are variable. Therefore, choices of site locations for service industries are like those of any other consumer when facing a location dectsion. That is, the firm, like the consumer, is confronted with a set of alternative location possibilities, i.e., SMSA, non-SMSA, or non-SMSA-nonadjacent market areas.

Thus, growth in each of the four segments of the service sector differs according to its area's industrial composition, demographics, population, income level, and location relative to the core. Although they may differ in many of their particulars, all service industries share the general trait of being located in metropolitan systems where 
there resides a sufficient consuming population and a fir narket. This is largely the reason why, among SMSA systems (represented by the various rings in Figure 3 , below), variability is deternined by the economic characteristics of locations.

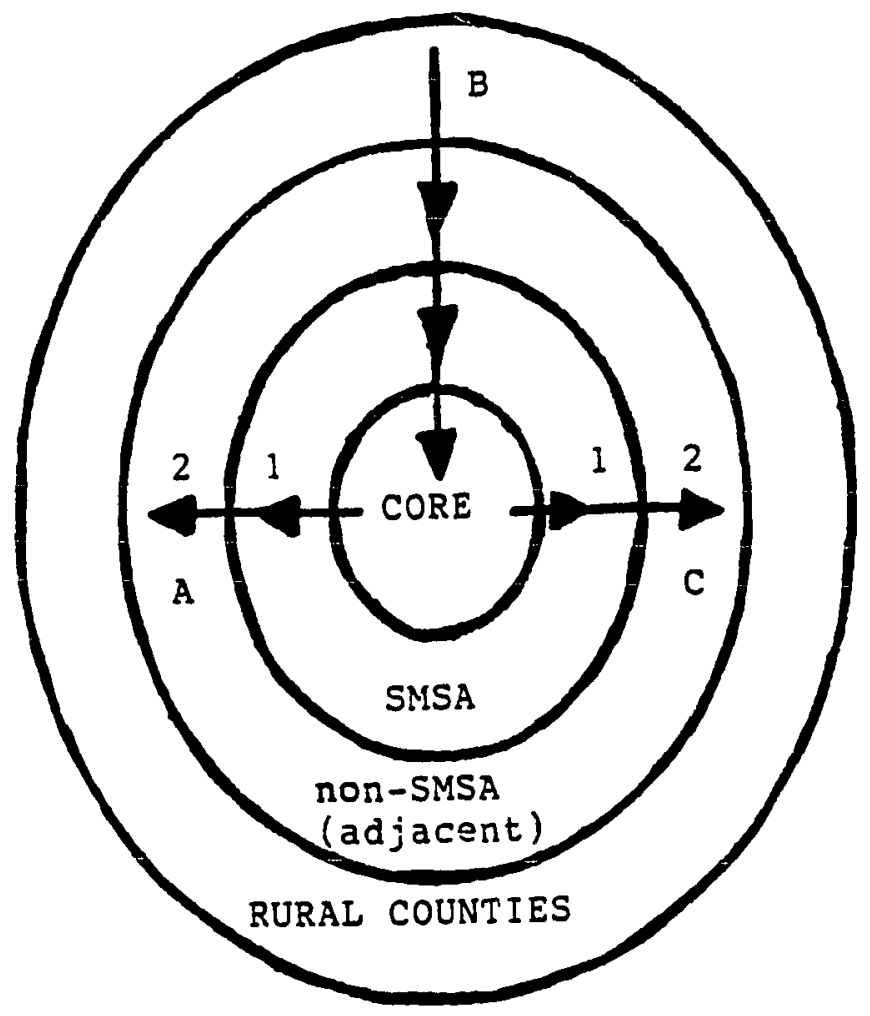

$A=$ Changes in location of manufacturing toward points

1 and 2 for inexpensive land and labor (See djscussion)

$B=$ Consumer travel to consume services not available in their own counties (export of services to other counties)

$C=$ Population movement toward the SMSA ring (1), and then toward the non-SMSA adjacent (2) (See discussion)

Figure 3. Schematic Diagram of Migration of Population and Manufacturers, and the Consequent Decentralization of Services

Further this variability in demand between the SMSA, non-SMSAadjacent, and non-SMSA-nonadjacent rings reflects the subsequent 
variability in the relative growth of the four major service industries over time.

The theoretical analysis has assumed, therefore, that the variable structure of the econony regarding the rings in Figure 3 during each time period has been accompanied by differences in $\mathrm{f}$ inal consumption and intermediate demand. Thus, the differences in the level of demand at different points in time reflects differences in the growth of the four segments of the service sector at different locations. Therefore, it is postulated that a higher intermediate demand relative to final consumer demand in any of the SMSAs will tend to attract business and distributive services, while a higher final consumer demand relative to intermediate demand in any of the SMSAS will correlate with the growth of personal and social services. However, the distribution of the four service industries individually or collectively falls off with increasing distance from the core. As a result of this, it is assumed that in the 1960s, the service industries grew in the SMSA $r$ ing, in the $1970 \mathrm{~s}$ in the non-SMSAadjacent ring, and that in the 1980s, they grew in the non-SMSAnonadjacent ring. 
CHAPTER IX

FORMLLATION OF THE MODEL

\section{INTRODUCTION}

This chapter will address the development of the Research Model, Phase One and the Research Model. Phase Two (the regional model). Multiple linear regression analyses will be developed on both models. The rationale behind the use of multiple linear regression is its explanatory power regarding the relationship between the dependent and the independent variables, as well as the relative importance of each of the predictive variables (from among those employed in the model). The independent variables employed in the multiple regressions are defined using information obtained from the literature presented in earlier chapters.

\section{HYPOTHESIS}

This study postulates that the share of total employment represented in the four segments of the service sector (distributive, personal, business, and social) in the 58 counties of California during the period $1960-1980$ is directly related to two broadly defined independent factors--growth of local markets and industrialization. As a result of the influence of these factors, it is postulated that the four segments of the service sectors further decentralize geographically (i.e., across the SMSA, non-SMSA adjacent, and the non- 
SMSA nonadjacent) in these same California counties during the same period (1960-1980).

RESEARCH MODEL. PHASE ONE

The first set of the model in Phase one consists of four dependent variables for each of the periods $(1960,1970.1980)$, for a total of 12 regression models and 58 observations. The final set of the model in phase one uses a pooled-time series for each service industry, for a total of four regression equations and 174 (58 $\times 3$ 3) observations.

In order to identify the existence of substitution and complementarity between services and with the manufacturing sector, a linear restriction is imposed on the coefficients of the three service segments and manufacturing industries that are employed as independent variables. For these independent variables the restriction is derived as a function of their relative proportions of total employment in a given period. The rationale for imposing a linear restriction is based on the prior knowledge of the relative proportions of employment in each of the segments of the service sector and the manufacturing sector. Thus, a service sector experiences either complementary or substitutive change as a result of a change in the relative proportion with other elements of the service or manufacturing sectors. The restriction is derived as follows: 
where

$B_{i}=$ The regression coefficient associated with independent sectoral variable $i$;

$P_{y}=$ The mean proportion of total employment associated with dependent sectoral variable y;

$P_{i}=$ The mean proportion of total employment associated with independent sectoral variable $i$.

Using the value of the proportion of employment for a dependent variable relative to each independent variable, a hypothesis test is developed as follows:

$$
\begin{aligned}
& H_{0}: B=r i \\
& H_{0}: B \lessgtr r i
\end{aligned}
$$

Complementarity exists between services if the growth of one service or manufacturing industry generates a proportionate change in the dependent variable equal to $r_{i}$. Accordingly, substitution implies that a particular service or manufacturing industry is in competition with other service industries. Thus, if a particular independent variable coefficient attributes higher or lower proportionate change than $r_{i}$, then the relationship is substitution.

At each step, the linear restricted coefficient in the regression model is inspected to determine its statistical significance.

The first set of linear restrictions and the unrestricted specific cross-sectional models for the dependent variables of the service industries for each time period $(1960,1970,1980)$ are: 


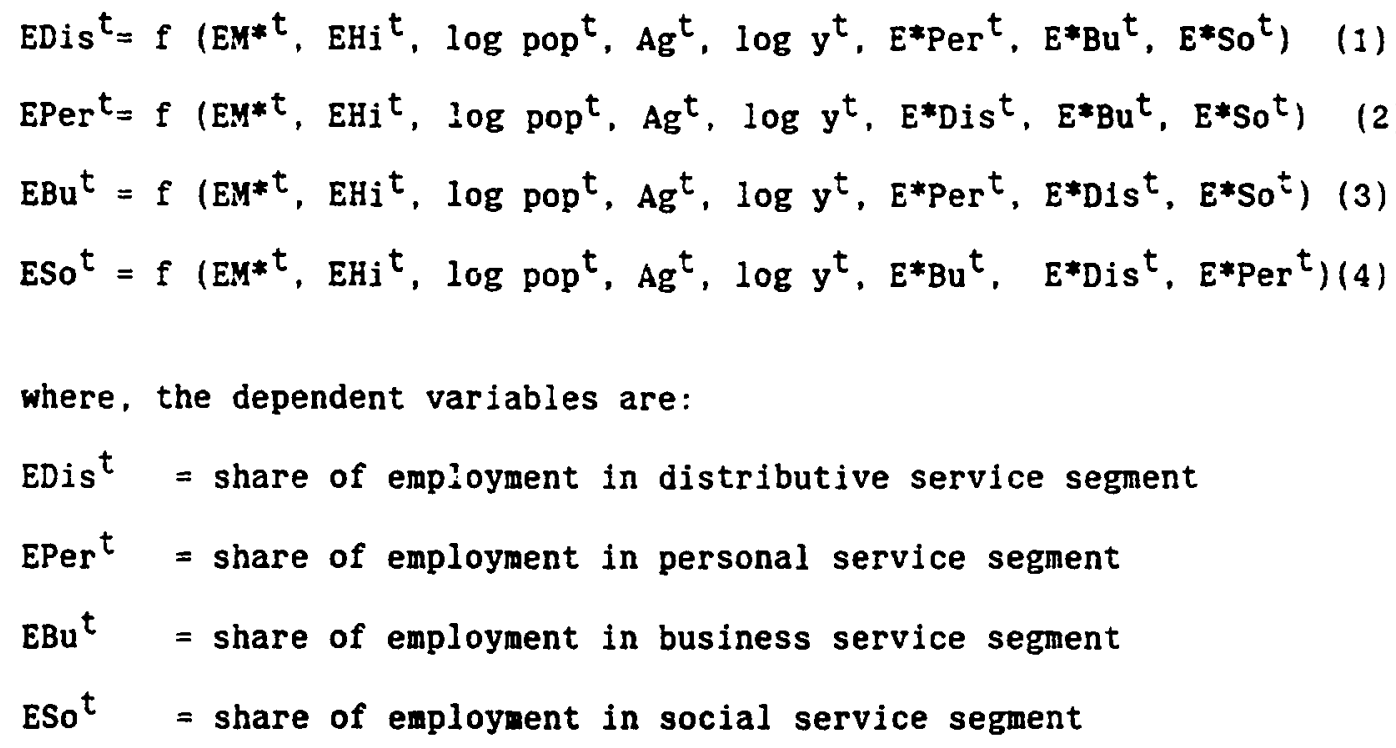

and the independent variables are:

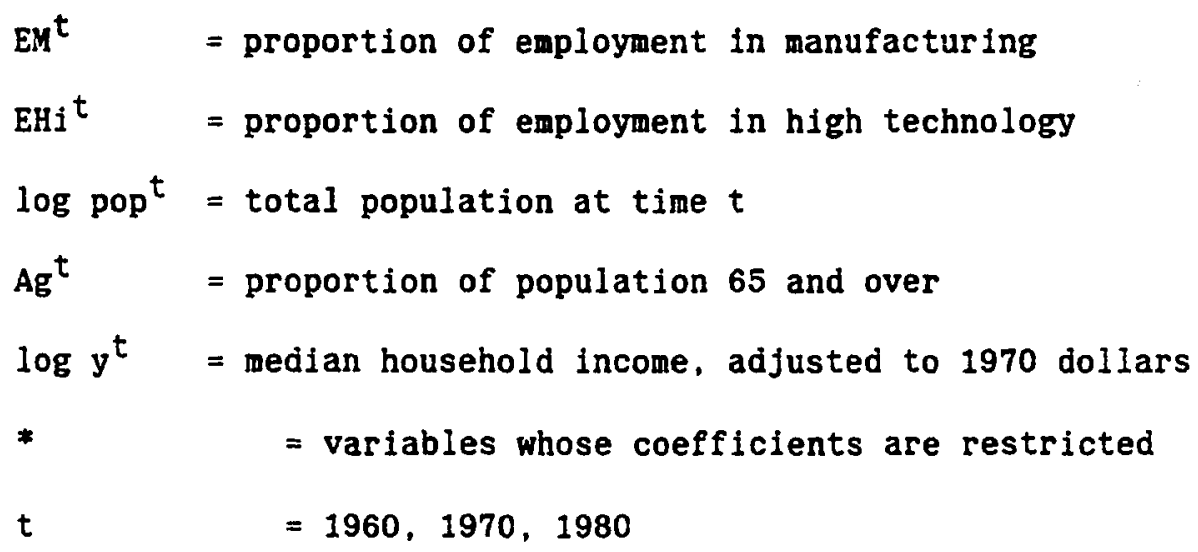

The second set of the multiple regression model is developed to run pooled-time series variables on the specific segments of the cross-section for the entire period 1960-1980.

$E D i s^{t}=f\left(E M^{* t}, E H i^{t}, \log \operatorname{pop}^{t}, A g^{t}, \log y^{t}, E^{*} \operatorname{Per}^{t}, E^{*} B u^{t}, E^{*} S o^{t}\right)$ (5) $E P e{ }^{t}=f\left(E M^{* t}, E H i^{t}, \log \operatorname{pop}^{t}, A g^{t}, \log y^{t}, E^{*} D i s^{t}, E^{*} B u^{t}, E^{*} S o^{t}\right)(6)$ $E B u^{t}=f\left(E M^{* t}, E H i^{t}, \log p o p t, A g^{t}, \log y^{t}, E^{*} \operatorname{Per}^{t}, E^{*} D i s^{t}, E^{*} S o^{t}\right)(7)$ $E S o^{t}=f\left(E M^{*} t, E H I^{t}, \log \operatorname{pop}^{t}, A g^{t}, \log y^{t}, E^{*} B u^{t}, E^{*} D i s^{t}, E^{*} \operatorname{Per}^{t}\right)(8)$ 
Where

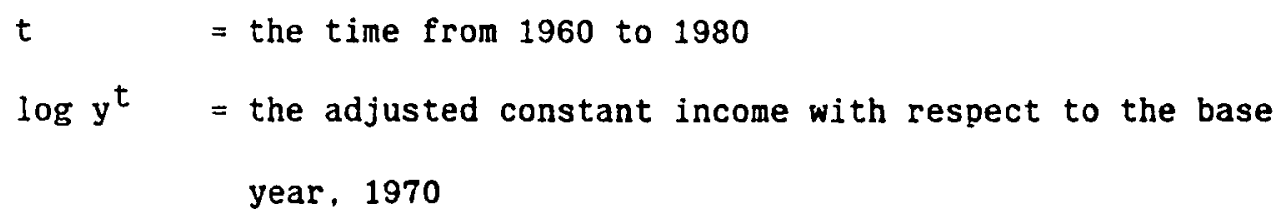

RESEARCH MODEL, PHASE TWO

This section carries the model developed in Phase one a step farther. In order to measure the influence of decentralization on the varlous service industries within the regional economy, three dummy variables are developed. These three dummy variables are based on:

$D^{1}=$ SMSA (Standard Metropolitan Statistical Areas) - non core counties $D^{2}=$ SMSA adjacent counties $D^{3}=$ non-SMSA nonadjacent counties

The core is being considered the basis on which the three dummy variables are to be compared as to the influence of decentralization on the service industries regionally. The three dummy variables will replace the three independent service industries that were employed in the previous model, for each service industry for 1960,1970 , and 1980.

$$
\begin{aligned}
& \text { EDis }{ }^{t}=f\left(E M^{* t}, E H 1^{t}, \log \text { pop } t, A g^{t}, \log y^{t}, D^{1 t}, D^{2 t}, D^{3 t}\right. \\
& E_{\text {Per }}{ }^{t}=f\left(E^{*} t, E H i^{t}, \ldots \log \text { pop }^{t}, A^{t}, \log y^{t}, D^{1 t}, D^{2 t}, D^{3 t}\right. \\
& E B u^{t}=f\left(E M^{*} t, E H i^{t}, \log \operatorname{pop}^{t}, A g^{t}, \log y^{t}, D^{1 t}, D^{2 t}, D^{3 t}\right. \\
& E S o^{t}=f\left(E M^{*} t, E H i^{t}, \log \operatorname{pop}^{t}, A g^{t}, \log y^{t}, D^{1 t}, D^{2 t}, D^{3 t}\right.
\end{aligned}
$$

where, the dependent variables are: 
EDis ${ }^{t}=$ share of employment in distributive services each time period EPer $^{t}=$ share of employment in personal services each time period $\mathrm{EBu}^{\mathrm{t}}=$ share of employment in business services each time period ESo $^{t}=$ share of employment in social services each time period and the independent variables are:

EMt $=$ proportion of employnent in manufacturing

$\mathrm{EHi}^{\mathrm{t}}=$ proportion of employment in high technology

$\log$ pop $^{t}=$ total population

$\mathrm{Ag}^{\mathrm{t}} \quad=$ proportion of population 65 and over

$\log y^{t}=$ median household income for each time period

$D^{1 \mathrm{t}} \quad=$ SMSA ring

$D^{2 t} \quad=$ non-SMSA adjacent

$D^{3 t} \quad=$ non-SMSA nonadjacent

$\mathrm{t} \quad=1960,1970,1980$

The second set of the regional model is developed by taking the sum of the total employment in the four service segments in each time period $(1960,1970,1980)$.

$$
f\left(E K_{t}, E H i_{t}, \log \operatorname{pop}_{t}, A g_{t}, \log y^{t}, D^{1}, D^{2}, D^{3}\right)
$$

where the dependent variables are:

= sum of employment shares in the four service sectors at time $\mathrm{t}$

SPECIFICATION OF THE VARIABLES

The Dependent Variable

This section presents all of the variables employed in the model, 
as well as the rationale for the relationship between the independent and the dependent variables. The dependent variables in the model that we are attempting to explain statistically have to do with the share of employ-ment in the specific segments of the service sector in 1960,1970 , and 1980 .

\section{The Independent Variables}

The independent variables of the model (the presumed determinants of the structure of employment in the various segments of the service sector) are divided into three major groups.

(1) Growth of the Local Market. Median household income and demographic characteristics are formulated as follows:

$\log$ pop $^{t}$ : total population at time $t$

$\log y^{t}: \quad$ median household income at time $t$

$\mathrm{Ag}^{\mathrm{t}}$ : proportion of population 65 and over

Log popt is assumed to be positively associated with service employment (Katouzian, 1970). Increasing population leads to an increase in employment within the various service industries as the market grows. The hypothes is here is that a county experiencing rapid population growth will be building a market for various service industries.

Log $y^{t}$ (median household income) is a key variable, because it reflects personal consumption expenditures (Clark, 1940; Stigler, 1956; Katouzian, 1970). It is reasonable to assume that the median income of residents in a given area will be essential to measuring the magnitude of the market demand for services. Since the market for 
services in a region is closely associated with the growth of income levels. Therefore, this variable is expected to show a positive correlation with the rise in employment in service industries.

The statistical test of income elasticity was performed using a level of 95 percent confidence interval based on the following hypothes is:

$$
\begin{aligned}
& H_{0}: B>1 \text { (elastic) } \\
& H_{0}: B<1 \text { (inelastic) }
\end{aligned}
$$

$\mathrm{Ag}^{\mathrm{t}}$ (percentage of the population 65 and over at time $t$ ) is expected to correlate positively with the dependent variable, since most consumers 65 and over depend on services located in their area or residence. However, the income of those 65 and over is generally a derived form of income and may not necessarily depend directly on local economic activity. Therefore, it is anticipated that this variable will have a positive coefficient, particularly with regard to social and personal services.

(2) Industrialization. The second industry-specific groups are identified as follows:

EMt Proportion of employment in manufacturing at time $t$

Ejf Proportion of employment in each of the service segments at time $t$ $E M^{t}$ is the share of employment in manufacturing industries and is a measure of industrialization in a county which generates income in the region. Generally, an increase in manufacturing employment in an area should stimulate increased activities in the business and distributive services. 
Ejf measures the share of employment in each segment of the service sector that is employed as an independent variable. The inclusion of this variable is based on the fact that the service industries have interrelated demand among themselves. The decisions made on the part of one service industry may affect other service industries either positively or negatively in employment. However, the impact of a particular service industry (independent variable) on the dependent variable is expected to vary, due to there being differing intermediate demand among the four service industries.

(3) Regional Variables. The third group of variables are dunmy variables designed to measure decentralization of service industries between metropolitan counties. These three are:

$D^{1}: 1$, for SMSA ring counties; 0 otherwise

$D^{2}: 1$, for counties adjacent to SMSA counties; 0 otherwise

$D^{3} 1$, for nonadjacent, non-SMSA counties; 0 otherwise

These variables are designed to identify intrametropolitan influences of service industries. The influence of decentralization of various segments of the service sector counties is assumed to reflect the relative accessibility to the central city (core). This hypothesis is based on the decentralization of manufacturing, population, and advances in transportation and communication, all of which influence the decentralization of the service sector.

Therefore, it is hypothesized that in 1960 the service industries are differentially concentrated in the Core Counties. By 1970, the industry is predicted to decentralize to the SMSA ring counties, and by 1980 , it is hypothesized to shift toward the adjacent SMSA and non- 
adjacent no-SMSA Counties. These hypotheses are based on research indicating that service sectors are following population and income outward through the SMSA's from the Core. (Mills, 1970; Cooke, 1978; Kellerman and Krakover, 1986; Steinner, 1982).

\section{RESEARCH ANALYSIS}

With the theoretical framework of the multiple regression analysis model of the several service industry segments completed, the next step is to test empirically the validity of the many function relationships that have been hypothesized.

The first stage of this process will be to define statistically the nature and the degree of these functional relationships. The second stage involves interpreting and analyzing the model. Phase One. This model has 12 regressions and four pooled regression models (a total of 16 regressions). Step three consists of analyzing the model developed for the regional variables (Phase Two), which has 12 regressions and three sets of sums, one for each year of total services (1960, 1970, and 1980), for a total of 15 regressions. The final stage will consist of examining the stability of the coefficients (referred to as the "Chow test"). 
CHAPTER X

RESEARCH RESULTS

INTRODUCTION

This chapter presents the results of the regression analysis constructed to explain the hypotheses for the four dependent variables. The series linear regression model was run on the Shazam computer program (White 1978). Output for this statistical package includes the coefficient of determination, estimates of $B$, and a test of the significance of the t-ratio.

Significance tests are reported for each of the coefficients and are derived using the t-test for the computed quantity. From available significance tests (that is, either a one- or two-tailed test), the two-tailed test of significance was selected.

In this chapter, various statistical analyses will be presented in order to show each variable's relevance. Additionally, cross reference tables are presented for inspection.

MODEL ONE: REGRESSION RESULTS FOR

MARKET-SIZE VARIABLES

\section{Distributive Industry (Dependent)}

The cross-sectional linear regression model for the periods 1960 . 1970, and 1980, as well as the time-series pooled results, are set out in Table IV. 
TABLE IV

REGRESSION RESULTS FOR MODEL ONE, EQUATION ONE

( $t$-ratio in parentheses)

\begin{tabular}{|c|c|c|c|c|}
\hline & $\begin{array}{l}\text { Distrib. } \\
1960\end{array}$ & $\begin{array}{l}\text { Distrib. } \\
1970\end{array}$ & $\begin{array}{l}\text { Distrib. } \\
1980\end{array}$ & $\begin{array}{l}\text { Total } \\
\text { Distrib. }\end{array}$ \\
\hline MANF & $\begin{array}{c}-0.36516 \\
(-2.5658)^{*}\end{array}$ & $\begin{array}{c}\mathrm{B} \\
-0.46086 \\
(-2.7897)^{*}\end{array}$ & $\begin{array}{c}\text { B } \\
0.10142 \\
(0.67144)\end{array}$ & 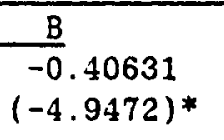 \\
\hline HITN & $\begin{array}{l}-0.38345 \\
1-0.80473\end{array}$ & $\begin{array}{c}-0.03803 \\
(-0.61455)\end{array}$ & $\begin{array}{l}-1.0529 \\
(-2.9612)^{*}\end{array}$ & $\begin{array}{c}-0.66688 \\
(-2.4258)^{*}\end{array}$ \\
\hline POPUL & $\begin{array}{c}0.04907 \\
(2.6762)^{*}\end{array}$ & $\begin{array}{c}0.07436 \\
(0.40711)\end{array}$ & $\begin{array}{c}0.01189 \\
(2.8340)^{* *}\end{array}$ & $\begin{array}{c}0.04367 \\
(4.8601)^{* *}\end{array}$ \\
\hline$\overline{\mathrm{AGE}}$ & $\begin{array}{c}1.0576 \\
(1.8945)\end{array}$ & $\begin{array}{l}-0.52136 \\
(-0.067253)\end{array}$ & $\begin{array}{c}0.15239 \\
(0.29147)\end{array}$ & $\begin{array}{r}0.62384 \\
(1.7690)\end{array}$ \\
\hline INC & $\begin{array}{c}0.15948 \\
(2.2017)^{*}\end{array}$ & $\begin{array}{c}0.12296 \\
(0.64305)\end{array}$ & $\begin{array}{c}-0.06897 \\
(-0.54902)\end{array}$ & $\begin{array}{c}0.11104 \\
(4.3770)^{* *}\end{array}$ \\
\hline PROD & $\begin{array}{l}-1.1538 \\
(-1.6011)\end{array}$ & $\begin{array}{r}-0.92877 \\
(-1.9293)\end{array}$ & $\begin{array}{c}-0.88728 \\
(-3.3926)^{*}\end{array}$ & $\begin{array}{l}-1.2573 \\
(-5.1846)^{*}\end{array}$ \\
\hline$\overline{\text { PER }}$ & $\begin{array}{c}-0.21697 \\
(-0.47723)\end{array}$ & $\begin{array}{c}-0.72099 \\
(-2.4092)^{*}\end{array}$ & $\begin{array}{l}-0.82029 \\
(-3.4106)^{*}\end{array}$ & $\begin{array}{c}-0.74274 \\
(-4.0934)^{*}\end{array}$ \\
\hline SOC & $\begin{array}{c}-0.38408 \\
(-0.45957)\end{array}$ & $\begin{array}{l}-0.0937 \\
(-0.15643)\end{array}$ & $\begin{array}{c}-0.65335 \\
(-2.1192)^{*}\end{array}$ & $\begin{array}{c}-1.0936 \\
(-3.8275)^{*}\end{array}$ \\
\hline $\mathrm{R}_{2}$ & 0.33 & 0.10 & 0.32 & 0.10 \\
\hline$\overline{\text { SEE }}$ & 0.14160 & 0.26409 & 0.12477 & 0.14680 \\
\hline $\bar{N}$ & 58 & 58 & 58 & 174 \\
\hline
\end{tabular}

* Significant at .05

** Significant at .01 
As expected, the coefficient representing the population variable proved to be an important determinant in explaining the relative growth of distributive service employment. As specified, the population coefficient indicated a positive association and is statistically significant at a level of .01 , although it lacks statistical significance in the cross-sectional equations for the period 1970. This may be due to its being randomly influenced by a cross-sectional transitory factor. The results acquire their greatest weight on the basis of the evidence provided by the positive statistical significance of the population coefficient in the crosssectional equations for 1960 (at .05) and 1980 (at .01), as well as from the time-series pooled model. Thus, population growth in California over the years is shown to be one of the basic causes of the relative growth of employment in the distributive service industries.

Another variable represents the age group 65 and over, and it indicates a positive--though statistically insignificant--relationship in all cross-sectional equations and in the pooled model. This may be a result of the age variable representing a narrow range of demand directed primarily at other services, and therefore not significantly affecting the relative growth of employment in the distributive services. This is reinforced in the model, which specifies that the age variable represents a population with a fixed income, and relatively more prone to consume social services than are other segments of the service sector. This is evident in the results shown in Table IX, in which the age coefficient explains the relative growth 
of social service employment across all time and in the pooled model. Relative growth of employment in distributive service is also explained by variable income. The logarithmic constant income coefficient was found to be positive and statistically significant at a level of .05 in the cross-sectional equation for 1960 and .01 for the time-series pooled model. Since the regressions were run in a log form, the regression coefficient for income can also be used as a measure of the income elasticity with respect to the four segments of the service sector. In the distributive services, this income elasticity is found to be less than one, which may indicate that consumers are not increasing expenditures significantly, indicating that expenditures increase less once a certain threshold income level has been attained.

Although the logarithmic income coefficient was found to be positive, it lacks statistical significance in the cross-sectional equations for the periods 1970 and 1980 . The pattern of the income coefficient's positive but insignificant relationship is consistent across the periods 1970 and 1980 , and across all segments of the service sector.

\section{Personal Services}

Surprisingly, the population coefficient displays a positive-though statistically insignificant--relationship in all equations developed for personal services in the periods 1960, 1970, and 1980 , as well as in the pooled model (see Table VII). Meanwhile, the age coefficient indicates a positive relationship, with statistical significance at the level of .05 percent, in the cross-sectional 
equation for 1960 , though not for the other time periods.

This result might be due to the fact that the level of demand for personal services is likely to be more strongly related to income, hence, consumer expenditure. Sabolo (1975) and Katouzian (1970) have stated that the relative growth of personal services (referred to as "new services") is associated positively with income. The empirical results shown in Table VII tend to confirm this, as well as confirming the hypothesis that the income coefficient indicates a positive relationship and statistical significance at a level of .01 percent in the cross-sectional equations for the period 1960 , as well as in the time-series pooled model.

However, the income elasticity of demand for personal services is inelastic. This might be because of the industry advances in innovation and efficiency, which might not require consumers to spend more of this incremental income. Thus, incremental increases in consumer income might not cause a significant change in expenditures for personal services.

Meanwhile, as was the case in Table VI, this coefficient also lacks statistical significance for predicting the relative growth of personal service employment in the cross-sectional equations for the periods 1970 and 1980 . The lack of statistical significance in the income coefficient seen in Tables VI, VII, and VIII confirms this recurrent pattern. At the same time, however, it was found that marked similarities exist with regard to income elasticities in both Tables VI and VII. For the 1960 period, the cross-sectional equation and the pooled model indicate an elasticity coefficient less than one. 


\section{TABLE V}

REGRESSION RESULTS FOR MODEL ONE, EQUATION TWO

(t-ratios in parentheses)

\begin{tabular}{|c|c|c|c|c|}
\hline & $\begin{array}{l}\text { Personal } \\
1960\end{array}$ & $\begin{array}{l}\text { Personal } \\
1970\end{array}$ & $\begin{array}{l}\text { Personal } \\
1980\end{array}$ & $\begin{array}{l}\text { Total } \\
\text { Personal }\end{array}$ \\
\hline MANF & $\begin{array}{l}-B \\
-0.20514 \\
(-7.7265)^{*}\end{array}$ & $\begin{array}{c}\mathrm{B} \\
-0.35546 \\
(-5.9942) *\end{array}$ & $\begin{array}{c}\mathrm{B} \\
-0.19442 \\
(-2.2833) *\end{array}$ & 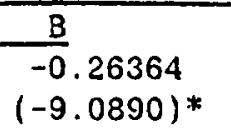 \\
\hline HITN & $\begin{array}{c}0.02697 \\
(0.21673)\end{array}$ & $\begin{array}{c}0.08448 \\
(0.35681)\end{array}$ & $\begin{array}{r}-0.27658 \\
(-1.4225)\end{array}$ & $\begin{array}{l}-0.06094 \\
(-0.59387)\end{array}$ \\
\hline POPUL & $\begin{array}{r}0.05359 \\
(1.1339)\end{array}$ & $\begin{array}{c}0.07207 \\
(0.10698)\end{array}$ & $\begin{array}{r}0.06892 \\
(1.1403)\end{array}$ & $\begin{array}{r}0.57897 \\
(1.7837)\end{array}$ \\
\hline$\overline{\mathrm{AGE}}$ & $\begin{array}{c}0.32912 \\
(2.2326)^{*}\end{array}$ & $\begin{array}{c}0.22599 \\
(0.73780)\end{array}$ & $\begin{array}{r}0.010381 \\
(0.38962)\end{array}$ & $\begin{array}{r}0.16914 \\
(1.3016)\end{array}$ \\
\hline INC & $\begin{array}{c}0.07434 \\
(4.0058)^{* *}\end{array}$ & $\begin{array}{r}0.032136 \\
(0.43561)\end{array}$ & $\begin{array}{c}0.01793 \\
(0.27307)\end{array}$ & $\begin{array}{c}0.031066 \\
(3.2962)^{* *}\end{array}$ \\
\hline DIST & $\begin{array}{r}-0.03672 \\
(-1.0645)\end{array}$ & $\begin{array}{r}-0.06472 \\
(-1.1857)\end{array}$ & $\begin{array}{l}-0.21351 \\
(-3.2301)^{*}\end{array}$ & $\begin{array}{c}-0.07225 \\
(-2.5926)^{*}\end{array}$ \\
\hline PROD & $\begin{array}{r}-0.24934 \\
(-1.3240)\end{array}$ & $\begin{array}{c}-0.53841 \\
(-2.9086)^{*}\end{array}$ & $\begin{array}{r}-0.21969 \\
(-1.7178)\end{array}$ & $\begin{array}{c}-0.26853 \\
(-3.0738)\end{array}$ \\
\hline SOC & $\begin{array}{l}-0.10380 \\
(-0.5290)\end{array}$ & $\begin{array}{r}0.21860 \\
(1.0840)\end{array}$ & $\begin{array}{r}-0.18238 \\
(-1.3286)\end{array}$ & $\begin{array}{r}-0.09558 \\
(-1.0175)\end{array}$ \\
\hline $\mathrm{R}^{2}$ & 0.56 & 0.40 & 0.22 & 0.32 \\
\hline$\overline{S E E}$ & 0.37515 & 0.62633 & 0.57795 & 0.54474 \\
\hline$N$ & 58 & 58 & 58 & 174 \\
\hline
\end{tabular}

* Significant at .05

** Significant at .01 
Business Services

Examination of the cross-sectional and time-series linear regression equations in Table VII reveals that the population coefficient is positive and statistically significant when explaining the relative employment growth in the business services. Thus, as expected, this variable, with a .01 level of statistical significance across all time periods, proves to be one of the indicators of the ways in which business service industries are relatively growing into large, multifaceted operations.

Another important variable from the linear expressions for the periods 1960 and 1970 and the time-series pooled model is the coefficient representing the age variable. This coefficient is positive and statistically significant at .05 and .01 .

As was expected, the income coefficient provided the best fit to both the linear regression cross-sectional equations for 1960 and the time-series pooled model, at levels of statistical significance of .05 and .01 percent, respectively. However, it lacks statistical significance in the periods 1970 and 1980. Again, though, as was observed in the estimated equations across both all sectors and the time periods 1970 and 1980, the income coefficient indicates a trend that is consistent (see Tables IV, V, VI, and VII). In the same way. business services is income inelastic. Since this segment of the service sector accounts for advanced technology and increased efficiency in the delivery of various kinds of services to consumers, it might not be necessary for consumers to increase expenditures significantly greater than the marginal increase in income. 
TABLE VI

REGRESSION RESULTS FOR MODEL ONE, EQUATION THREE

$(t$-ratios in parentheses)

\begin{tabular}{|c|c|c|c|c|}
\hline & $\begin{array}{l}\text { Business } \\
1960\end{array}$ & $\begin{array}{l}\text { Business } \\
1970\end{array}$ & $\begin{array}{l}\text { Business } \\
1980\end{array}$ & $\begin{array}{l}\text { Total } \\
\text { Business }\end{array}$ \\
\hline MANF & $\begin{array}{l}\frac{B}{-0.10144} \\
(-4.2601)^{*}\end{array}$ & $\frac{\mathrm{B}}{-0.16169}$ & 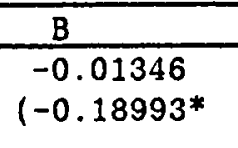 & 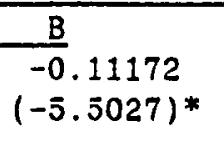 \\
\hline HITN & $\begin{array}{c}0.05472 \\
(0.69232)\end{array}$ & $\begin{array}{c}-0.08906 \\
(-0.73889)\end{array}$ & $\begin{array}{c}-0.25311 \\
(-1.45039)\end{array}$ & $\begin{array}{r}-0.08666 \\
(-1.2577)\end{array}$ \\
\hline POPUL & $\begin{array}{c}0.01610 \\
(5.4477)^{* *}\end{array}$ & $\begin{array}{c}0.92728 \\
(3.5311)^{* *}\end{array}$ & $\begin{array}{c}0.01637 \\
(3.0778)^{* *}\end{array}$ & $\begin{array}{c}0.01466 \\
(6.5917)^{* *}\end{array}$ \\
\hline$\overline{\mathrm{AGE}}$ & $\begin{array}{c}0.31579 \\
(3.4020)^{* *}\end{array}$ & $\begin{array}{c}0.39738 \\
(2.5546)^{*}\end{array}$ & $\begin{array}{r}0.41391 \\
(1.7722)\end{array}$ & $\begin{array}{c}0.34669 \\
(3.9240)^{* *}\end{array}$ \\
\hline$\overline{\text { INC }}$ & $\begin{array}{c}0.02603 \\
(2.1373)^{*}\end{array}$ & $\begin{array}{r}0.04277 \\
(1.1510)\end{array}$ & $\begin{array}{c}0.05610 \\
(0.99615)\end{array}$ & $\begin{array}{c}0.03409 \\
(5.4038)^{* *}\end{array}$ \\
\hline$\overline{\text { PER }}$ & $\begin{array}{r}-0.14438 \\
(-1.9331)\end{array}$ & $\begin{array}{c}-0.17652 \\
(-3.0241)^{*}\end{array}$ & $\begin{array}{r}-0.11339 \\
(-1.1023)\end{array}$ & $\begin{array}{c}-0.11958 \\
(-2.7283)^{*}\end{array}$ \\
\hline$\overline{\mathrm{DIST}}$ & $\begin{array}{c}-0.05218 \\
(-2.4063)^{*}\end{array}$ & $\begin{array}{c}-0.06235 \\
(-0.22519)\end{array}$ & $\begin{array}{c}-0.15656 \\
(-2.7079)^{*}\end{array}$ & $\begin{array}{c}-0.05085 \\
(-2.7212)^{*}\end{array}$ \\
\hline$\overline{\mathrm{SOC}}$ & $\begin{array}{c}-0.02200 \\
(-0.24084)\end{array}$ & $\begin{array}{c}-0.02556 \\
(-0.30228)\end{array}$ & $\begin{array}{c}-0.27659 \\
(-2.0793)^{*}\end{array}$ & $\begin{array}{c}-0.13784 \\
(-2.4399)^{*}\end{array}$ \\
\hline $\mathrm{R}_{2}$ & 0.60 & 0.49 & 0.26 & 0.44 \\
\hline$\overline{S E E}$ & 0.23523 & 0.31630 & 0.50090 & 0.13352 \\
\hline $\mathrm{N}$ & 58 & 58 & 58 & 174 \\
\hline
\end{tabular}

* Significant at .05

** Significant at .01 


\section{Social Services}

The linear regression model indicates that population, age, and income variables are both statistically significant and positive, as shown in Table IX. The cross-sectional regression equations for the periods 1960, 1970, and 1980, as well as the pooled model. indicate that the population coefficient is significant at a level of .01 percent and is positively associated with the relative growth of employment in the social services. Similarly, the age coefficient, as expected, confirmed the positive statistical significance at a level of .01 percent in the pooled model and in the cross-sectional equations for the periods 1960 and 1970 , and at .05 percent for 1980 . In other words, the population coefficient and the age coefficient explain relative employment growth in social service industries across all periods investigated in the linear regression models.

Additionally, the logarithmic income coefficient was found to be positive and statistically significant at the level of .05 percent for the period 1960 and at a level of .01 percent in the pooled model. Thus, the theory that has been discussed (that as income increases, the demand for social services also increases) appears to be confirmed. On the other hand, the existence of an insignificant income coefficient in the cross-sectional equations for 1960 and 1970 is also consistent across time and in all segments of the service sector, as is shown in all tables.

Income elasticity for social services is not different from the other services, in that the elasticity for social services is income inelastic in both the cross-sectional equation for 1960 and in the 
pooled model. One explanation for income inelasticity in the social services is that consumers at all levels might direct large shares of their incremental income to other forms of consumption once their needs are met.

As a whole, relative employment growth in social service industries, as expected, results from a growing population. rising personal income, and increased longevity. 


\section{TABLE VII}

REGRESSION RESULTS FOR MODEL ONE, EQUATION FOUR

( $t$-ratios in parentheses)

\begin{tabular}{|c|c|c|c|c|}
\hline & $\begin{array}{l}\text { Social } \\
1960\end{array}$ & $\begin{array}{l}\text { Social } \\
1970\end{array}$ & $\begin{array}{l}\text { Social } \\
1980\end{array}$ & $\begin{array}{l}\text { Total } \\
\text { Social }\end{array}$ \\
\hline MANF & $\begin{array}{l}\frac{B}{-0.05990} \\
(-3.7105)^{*}\end{array}$ & 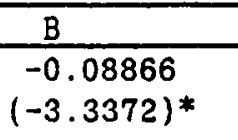 & 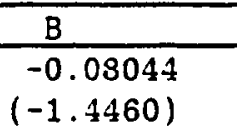 & 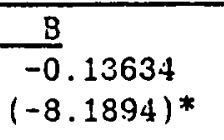 \\
\hline HITN & $\begin{array}{c}-0.13598 \\
(-2.3165)^{*}\end{array}$ & $\begin{array}{r}-0.15592 \\
(-1.3990)\end{array}$ & $\begin{array}{r}-0.14078 \\
(-1.0945)\end{array}$ & $\begin{array}{l}-0.14333 \\
(-2.3383)^{*}\end{array}$ \\
\hline POPUL & $\begin{array}{c}0.09673 \\
(4.1269) * *\end{array}$ & $\begin{array}{c}0.01672 \\
(5.1816)^{* *}\end{array}$ & $\begin{array}{c}0.01422 \\
(3.5173)^{* *}\end{array}$ & $\begin{array}{c}0.01575 \\
(8.0956) * *\end{array}$ \\
\hline$\overline{\mathrm{AGE}}$ & $\begin{array}{c}0.34186 \\
(4.8772)^{* *}\end{array}$ & $\begin{array}{c}0.42647 \\
(2.9513)^{*}\end{array}$ & $\begin{array}{c}0.42964 \\
(2.4280)^{* *}\end{array}$ & $\begin{array}{c}0.47273 \\
(6.2131)^{* *}\end{array}$ \\
\hline INC & $\begin{array}{c}0.02000 \\
(2.2047)^{*}\end{array}$ & $\begin{array}{c}0.01845 \\
(0.53162)\end{array}$ & $\begin{array}{c}0.01115 \\
(0.25762)\end{array}$ & $\begin{array}{c}0.03598 \\
(6.5038)^{* *}\end{array}$ \\
\hline$\overline{\mathrm{DIST}}$ & $\begin{array}{r}-0.02872 \\
(-1.7700)\end{array}$ & $\begin{array}{c}-0.01462 \\
(-0.58259)\end{array}$ & $\begin{array}{r}-0.07537 \\
(-1.8125)\end{array}$ & $\begin{array}{c}-0.05178 \\
(-3.2573)^{*}\end{array}$ \\
\hline$\overline{\text { PROD }}$ & $\begin{array}{l}-0.03136 \\
(-0.53219)\end{array}$ & $\begin{array}{l}-0.20514 \\
(-3.3315)=\end{array}$ & $\begin{array}{l}-0.21955 \\
(-2.7074) *\end{array}$ & $\begin{array}{l}-0.36696 \\
(-8.9974) *\end{array}$ \\
\hline$\overline{\text { PER }}$ & $\begin{array}{r}-0.08002 \\
(-1.5694)\end{array}$ & $\begin{array}{r}-0.21860 \\
(-1.3132)\end{array}$ & $\begin{array}{r}-0.09464 \\
(-1.4060)\end{array}$ & $\begin{array}{c}-0.18493 \\
(-5.4356)^{*}\end{array}$ \\
\hline $\mathrm{R}_{2}$ & 0.50 & 0.40 & 0.21 & 0.30 \\
\hline SEE & 0.17844 & 0.29521 & 0.38203 & 0.31952 \\
\hline$N$ & 58 & 58 & 58 & 174 \\
\hline
\end{tabular}

* Significant at .05

** Significant at .01 


\section{Industrial variables}

The coefficient for the manufacturing variables sheds light on the substitution relationship between it and the relative growth of personal service industries in the cross-sectional equations for 1960 , 1970, and in the pooled model. The empirical result indicates the existence of asymmetrical relationship between the four service industries. That may have been due to the fact that some service industries have a strong influence on the other service sectors, while others might have a mild one. For example, a fall in the price of coffee complements an increase in the demand for cream, while a fall in the price of cream might not increase the demand for coffee. The negative sign of the manufacturing coefficient in relation to the relative growth of personal services employment is statistically significant at a level of .05 percent in all periods. This is an indication that an increase in relative employment in manufacturing corresponds with declines in the relative employment in the personal services.

Moreover, the coefficient for manufacturing employment indicates a negative association with social services employment in the pooled model (statistically significant at .05 percent). The substitution relationship between manufacturing and the relative growth of social services employment is similar to results showing a substitution relationship between manufacturing and personal services employment. However, there exists a complementary relationship between social and personal services employment. This illustrates that growth in employment in manufacturing does not reflect direct demand with 
personal and social services for production and commercialization.

TABLE VIII

COMPLEMENTARY AND SUBSTITUTION RELATIONSHIPS AMONG INDUSTRIES IN 1960, 1970, AND 1980

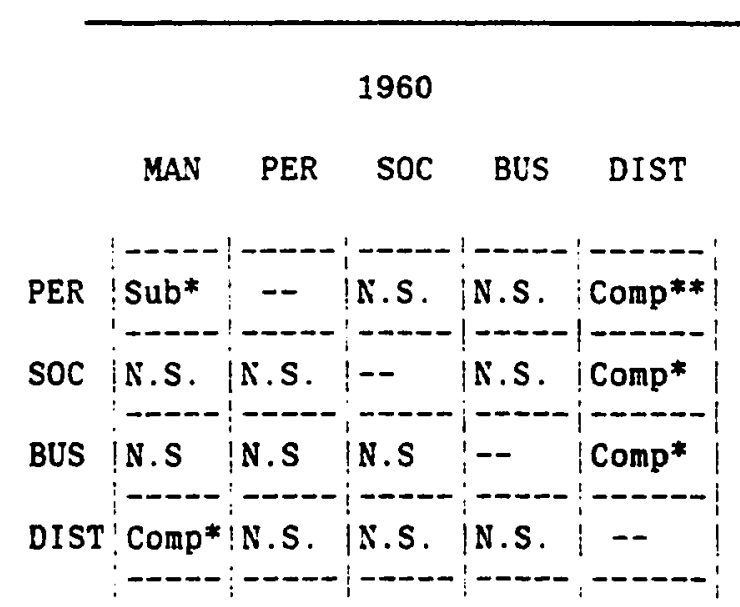

1980

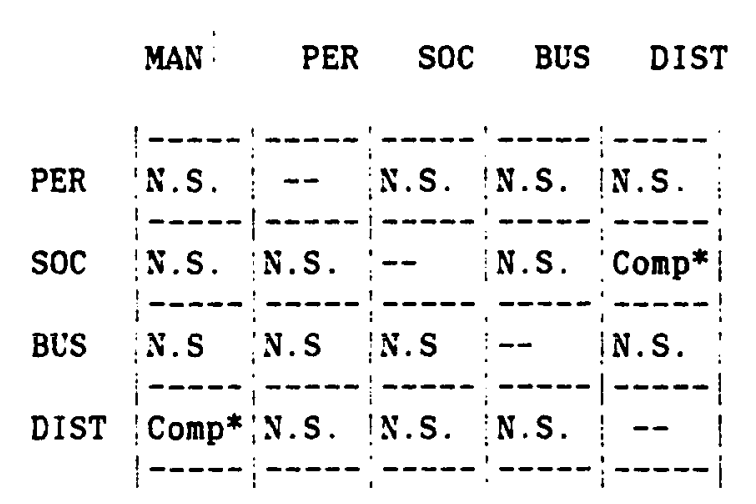

* Significant at .05

** Significant at .01

N.S. = No significant relationship Comp = Complementary relationship Sub = Substitution relationship
1970

MAN PER SOC BUS DIST

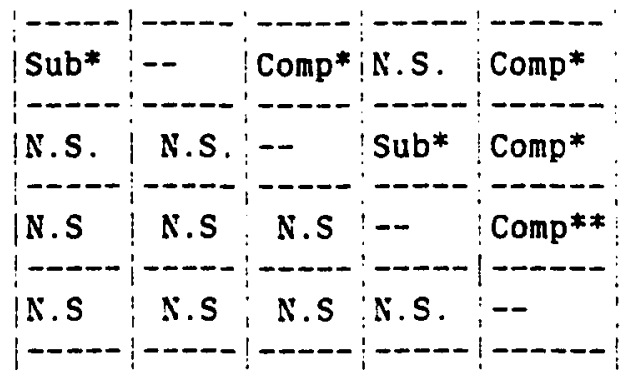

TOTALS

MAN PER SOC BUS DIST

$$
\begin{aligned}
& \text { MAN = Manufacturing } \\
& \text { PER = Personal Services } \\
& \text { SOC = Social Services } \\
& \text { BLS = Business Services } \\
& \text { DIST }=\text { Distributive Services }
\end{aligned}
$$

All horizontal axes represent independent variables; all vertical axes represent dependent vạiables 
The coefficient for the manufacturing variable indicates statistical significance at .05 percent, which is complementary to that for the relative growth of distributive services in the periods 1960 and 1980 , and in the pooled model. This complementary relationship between employment in manufacturing and the distributive services indicates the existence of intermediate demand between the two. The complenentarity between them suggests an increase in interindustry demand, which leads to an increase in employment in both sectors. This link between manufacturing and the relative growth of distributive services, which is confirmed in the empirical evidence, suggests the validity of theories proposed by Kuznets (1980) and others. From this relationship, then, one may recognize that the relative growth of distributive services respond to activity in manuf acturing.

The coefficient for personal services indicates a complementary relationship with relative employment growth in the social services (significant at .05) in the time-series pooled model, a relationship that clearly demonstrates that the two induce positive employment activities on one another. Further, the social services coefficient also shows a significant complementary relationship (at .05 percent) with personal services employment in 1970. It is clear, then, that the two have a positive relationship, resulting in corresponding growth in employment in both. This link between relative employment growth in the personal and relative growth in the social services may be due to both being strongly dependent on the demand of final consumers, as it appears to be in the earlier analysis. 
The cross-sectional regression for 1970 and the pooled model indicates a substitution relationship between business and social services (significant at .05 percent).

The coefficient for distributive services indicates a complementary relationship between it and personal services (significant at .05 percent) in all cross-sectional equations and in the pooled model. This pattern indicates that relative growth of employment in the distributive services will reflect corresponding relative growth in the personal services.

The coefficient for distributive services employment indicates a complementary relationship with social services employment, whereby growth in employment in the distributive services positively affects employment growth in the social services. In assessing the results shown in Table $X$, the pattern of this relationship is consistent in cross-sectional equations and in the time-series pooled model. Also shown in the data in Table $x$ is that a complementary relationship exists between the distributive services and business services (significant at .05 percent), and is present in all cross-sectional equations and in the pooled model. This result was expected, and it is consistent with the hypothesis, in that business services carry on complex corporate activities and have the need for distributive services. On the other hand, distributive services likewise require the presence of healthy corporate activity of the kind provided by business service industries. Thus, the existence of complementarity between the two service industries indicates, as expected, consequent intermediate demand, which conforms to the existence of a positive 
employment relationship.

SECTOR COMPARISON OF THE TIME-SERIES POOLED MODELS

Growth of the Local Market (Independent)

The results in Table IX indicate that the population variable reveals positive and statistically significant (at .01 percent) relationship in explaining the relative growth of three of the four service industries (i.e., distributive, business, and social services). As expected, the relationship conforms to the overall theory of the growth of employment in the service sector, which hypothesizes that the growth of service sector industries is induced by the expanding size of the market resulting from the growth of the general population.

The coefficient representing the 65 -and-over age variable exhibits a positive relationship, with a statistical significance of .01, as a factor influencing the growth of employment in both the business and social services. The significant association of this variable with the relative growth of social services was expected; however, its positive and statistically significant relationship with the relative growth of business services employment is not quite in line with the expected outcome. One explanation for this may be the increasing population of retired persons enjoying better pension benefits that are increasing the demand on business services, as well as on social services.

Regarding the expected outcome, of special interest is that the incone coefficient exhibits a positive and statistically significant (at .01 percent) relationship with the relative growth of all four of 
the service industries (namely distributive, business, personal and social services). Thus, the relative growth of employment in all service industries is due significantly to income (see Table XI). This finding lends empirical support to the theory that income contributes to the propelling of employment toward the service sector (Fischer, 1930; Clark, 1940; et al.). 
TABLE IX

SECTOR COMPARISONS OF THE TIME-SERIES

POOLED MODELS

( $t$-ratios in parentheses)

\begin{tabular}{|c|c|c|c|c|}
\hline & $\begin{array}{c}\text { Total } \\
\text { Distributive }\end{array}$ & $\begin{array}{c}\text { Total } \\
\text { Personal }\end{array}$ & $\begin{array}{c}\text { Total } \\
\text { Business }\end{array}$ & $\begin{array}{l}\text { Total } \\
\text { Social }\end{array}$ \\
\hline MANF & $\begin{array}{l}\frac{B}{-0.040631} \\
(-4.9472)\end{array}$ & 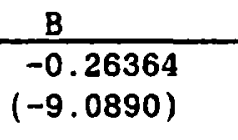 & $\frac{B}{-0.11172}$ & $\frac{B}{-0.13634}$ \\
\hline HITN & $\begin{array}{r}-0.66688 \\
(-2.4258)\end{array}$ & $\begin{array}{c}-0.06094 \\
(-0.59387)\end{array}$ & $\begin{array}{r}-0.08666 \\
(-1.2577)\end{array}$ & $\begin{array}{r}-0.14333 \\
(-2.3883)\end{array}$ \\
\hline POPUL & $\begin{array}{c}0.04367 \\
(4.8601)^{* *}\end{array}$ & $\begin{array}{r}0.05789 \\
(1.7837)\end{array}$ & $\begin{array}{c}0.01466 \\
(6.5917)^{* *}\end{array}$ & $\begin{array}{c}0.01575 \\
(8.0956)^{* *}\end{array}$ \\
\hline AGE & $\begin{array}{r}0.62384 \\
(1.7690)\end{array}$ & $\begin{array}{r}0.16914 \\
(1.3016)\end{array}$ & $\begin{array}{c}0.34669 \\
(3.9240)^{* *}\end{array}$ & $\begin{array}{c}0.47273 \\
(6.2131)^{* *}\end{array}$ \\
\hline INC & $\begin{array}{c}0.11104 \\
(4.3770)^{* *}\end{array}$ & $\begin{array}{c}0.031066 \\
(3.2962) * *\end{array}$ & $\begin{array}{c}0.03409 \\
(5.4038)\end{array}$ & $\begin{array}{c}0.03598 \\
(6.5038)^{* *}\end{array}$ \\
\hline PROD & $\begin{array}{l}-1.2573 \\
(-5.1846)\end{array}$ & $\begin{array}{l}-0.07225 \\
(-2.5926)\end{array}$ & $\begin{array}{l}-0.11958 \\
(-2.7283)\end{array}$ & $\begin{array}{r}-0.05178 \\
(-3.2573)\end{array}$ \\
\hline PER & $\begin{array}{l}-0.74274 \\
(-4.0934)\end{array}$ & $\begin{array}{l}-0.26853 \\
(-3.0738)\end{array}$ & $\begin{array}{l}-0.05085 \\
(-2.7212)\end{array}$ & $\begin{array}{r}-0.36696 \\
(-8.9974)\end{array}$ \\
\hline$\overline{\mathrm{SOC}}$ & $\begin{array}{c}-1.0936 \\
(-3.8275)\end{array}$ & $\begin{array}{l}-0.09558 \\
(-1.0175)\end{array}$ & $\begin{array}{r}-0.13784 \\
(-2.4399)\end{array}$ & $\begin{array}{l}-0.09558 \\
(-5.4356)\end{array}$ \\
\hline $\mathbf{R}_{2}$ & 0.10 & 0.32 & 0.44 & 0.30 \\
\hline SEE & 0.14680 & 0.54474 & 0.13352 & 0.31952 \\
\hline
\end{tabular}

** Significant at .01

$N=174$ 
Industrial Variables, (Independent)

The coefficient for manufacturing industries in the time-series pooled model expresses selective patterns of relationships between it and the four segments of the service sector. The coeficient for the manufacturing employment share, as shown in Table XII, exhibits a statistically significant (at .01 percent) complementary relationship with relative employment in the distributive services, but a substitution relationship with relative employment in the personal and social services. The complementary relationship between manufacturing and the distributive services is straightforward since the distributive services are an important requirement for manufacturing industries in transporting and distributing goods to the final market. Thus, employment growth in manufacturing corresponds with employment growth in distributive service industries. 
TABLE $X$

COMPLEMENTARY AND SUBSTITUTION RELATIONSHIPS

AKONG INDUSTRIAL VARIABLES IN THE

TIME-SERIES POOLED MODEL

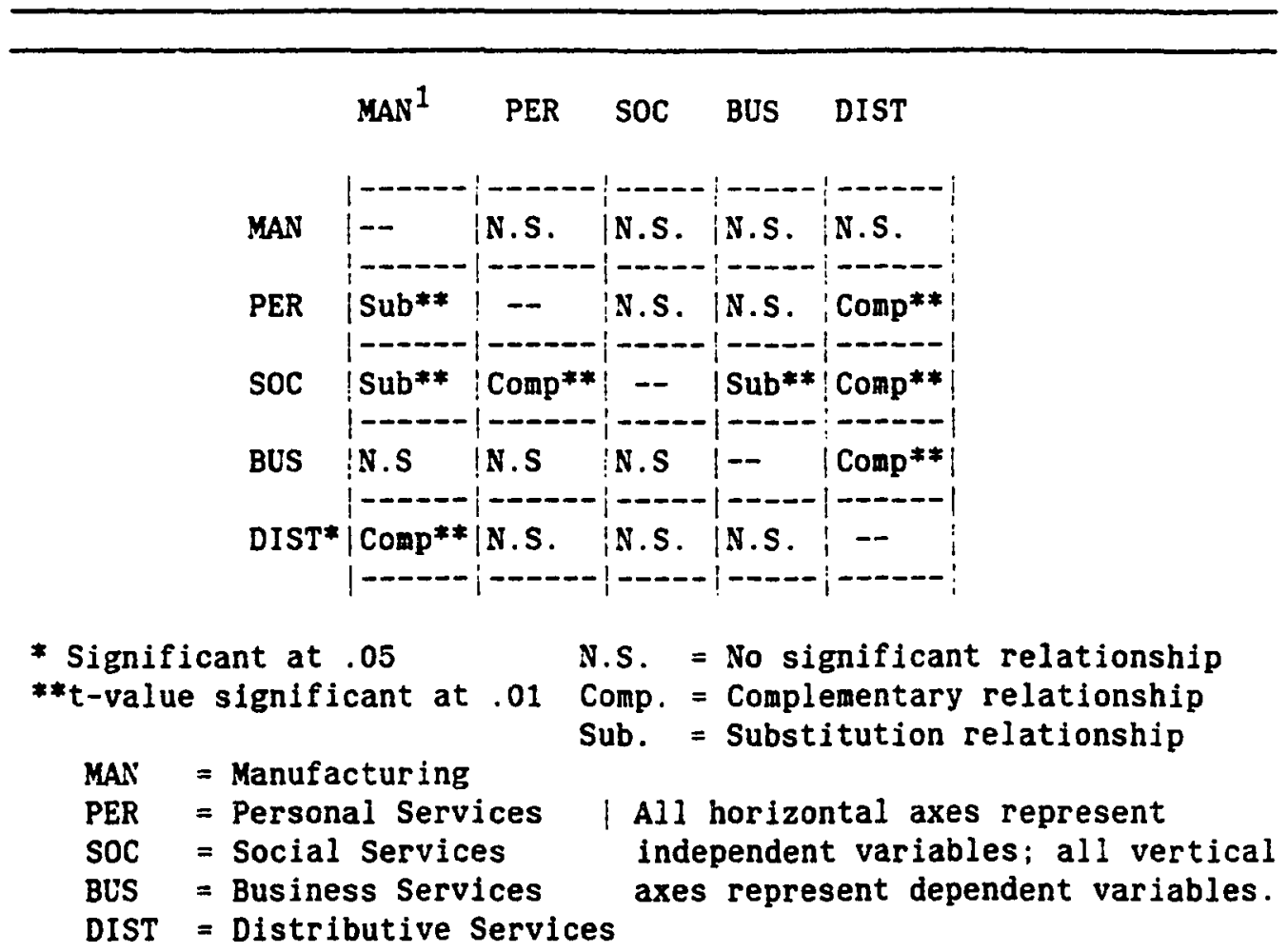

The negative significant relationship between manufacturing and both personal and social services employment is evidence that manufacturing is unrelated to either. The substitutional relationship between them indicates that the growth of manufacturing employment tends to repel or attract employment from personal and social service industries. This probably reflects a condition in which the social and personal services can rarely meet the wage competition of the manufacturer sector.

The coefficient representing personal services employment exhibits a significantly related (at .01 percent) complementary 
relationship with employment in the social services. This may be due to the fact that the personal and social services offer comparable wages, and that both are largely dependent on growth of demand from final consumers. The business service coefficient, on the other hand, exhibits a statistically significant (at .01 percent) substitution relationship with the social services, while failing to indicate either a positive or negative significant relationship with either of the other three service industries.

An interesting pattern of associations emerges from the outcome of the coefficient for distributive services, in that it is significant (at .01 percent) in a complementary relationship with all other service industries (personal, social, and business services). The complementary relationship between distributive services and business services and both the social and personal services reflects the degree to which the distributive services are dependent on final consumers. The complementary relationship between distributive services and business services, on the other hand, reflects the degree to which distributive services are dependent on intermediate demand. Thus, the mix of demand that confronts the distributive services relates positively (complenents) the other three service industries.

MODEL TWO: REGRESSION RESULTS

FOR THE REGIONAL VARIABLES

The estimated coefficient of the dummy variable for explaining the relative location of employment growth in the distributive services for the periods 1960, 1970, and 1980 lack statistical 
significance, as is shown in Table XII. The coefficients of dummy variables one, two, and three, representing the SMSA ring, the nonSMSA-adjacent, and the non-SMSA-nonadjacent counties, indicate that there is no sigrificant difference in the relative growth service employment across counties in tine periods 1960, 1970, and 1980. The model for the personal services also indicates statistical insignificance, which is shown in Table XIV. The SMSA, non-SMSAadjacent, and the non-SMSA-nonadjacent counties represented by the dummy variables also show that there are no significant differences among the three locations regarding the relative growth of personal services employment.

Across the three time periods, the three dumm variables indicate a positive pattern of association with the relative growth of social services employment, as shown in Table $\mathrm{XV}$. However, the relationship lacks statistical significance across locations. 
TABLE XI

REGRESSION RESULTS FOR MODEL TWO:

DISTRIBUTIVE SERVICES INDUSTRIES

( $t$-ratios in parentheses)

\begin{tabular}{|c|c|c|c|}
\hline & 1960 & 1970 & 1980 \\
\hline MANF & $\begin{array}{l}\frac{B}{-0.27626} \\
(-1.9990)\end{array}$ & $\begin{array}{c}\mathrm{B} \\
-0.09208 \\
(-0.54369)\end{array}$ & 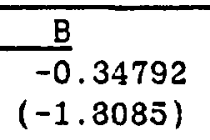 \\
\hline HITN & $\begin{array}{c}-0.14099 \\
(-0.27064)\end{array}$ & $\begin{array}{c}-0.19811 \\
(-0.31204)\end{array}$ & $\begin{array}{c}-0.7934 \\
(-2.0142)\end{array}$ \\
\hline$\overline{\text { POPUL }}$ & $\begin{array}{c}0.04044 \\
(2.0500)^{*}\end{array}$ & $\begin{array}{c}-0.04778 \\
(-0.26402)\end{array}$ & $\begin{array}{c}0.06320 \\
(0.39512)\end{array}$ \\
\hline$\overline{A G E}$ & $\begin{array}{c}0.54697 \\
(0.92998)\end{array}$ & $\begin{array}{l}-0.97139 \\
(-1.240)\end{array}$ & $\begin{array}{c}-0.45678 \\
(-0.81520)\end{array}$ \\
\hline INC & $\begin{array}{r}0.10919 \\
(1.6803)\end{array}$ & $\begin{array}{c}0.10466 \\
(0.51851)\end{array}$ & $\begin{array}{r}-0.28850 \\
(-1.6366)\end{array}$ \\
\hline$D^{1}$ & $\begin{array}{c}-0.04110 \\
(-0.55338)\end{array}$ & $\begin{array}{c}-0.05133 \\
(-0.70500)\end{array}$ & $\begin{array}{c}0.01287 \\
(0.23557)\end{array}$ \\
\hline$D^{2}$ & $\begin{array}{c}0.01882 \\
(0.27354)\end{array}$ & $\begin{array}{c}-0.04618 \\
(-0.69248)\end{array}$ & $\begin{array}{r}-0.08349 \\
(-1.3988)\end{array}$ \\
\hline$D^{3}$ & $\begin{array}{c}0.06259 \\
(0.73585)\end{array}$ & $\begin{array}{c}-0.06507 \\
(-0.89521)\end{array}$ & $\begin{array}{c}-0.06102 \\
(-0.82049)\end{array}$ \\
\hline $\mathrm{R}^{2}$ & 0.30 & 0.11 & 0.24 \\
\hline $\bar{F}$ & $2.227^{\star}$ & 0.508 & 1.833 \\
\hline$\overline{\mathrm{SEE}}$ & 0.14922 & 0.16361 & 0.11990 \\
\hline$\overline{\mathrm{N}}$ & 58 & 58 & 58 \\
\hline
\end{tabular}


TABLE XII

REGRESSION RESULTS FOR MODEL TWO: PERSONAL SERVICES INDUSTRIES

( $t$-raijus in parentheses)

\begin{tabular}{|c|c|c|c|}
\hline & 1960 & 1970 & 1980 \\
\hline MANF & $\begin{array}{l}-\frac{B}{-0.21522} \\
(-5.8731)^{*}\end{array}$ & 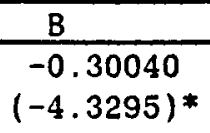 & 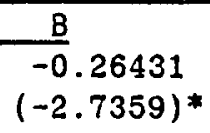 \\
\hline HITN & $\begin{array}{c}0.07728 \\
(0.57569)\end{array}$ & $\begin{array}{c}0.04422 \\
(0.17001)\end{array}$ & $\begin{array}{l}-0.05539 \\
(-0.28003)\end{array}$ \\
\hline POPUL & $\begin{array}{c}-0.01391 \\
(-0.26841)\end{array}$ & $\begin{array}{c}-0.05317 \\
(-0.71726)\end{array}$ & $\begin{array}{c}-0.03263 \\
(-0.40617)\end{array}$ \\
\hline AGE & $\begin{array}{r}0.19982 \\
(1.3212)\end{array}$ & $\begin{array}{c}0.20260 \\
(0.63183)\end{array}$ & $\begin{array}{l}-0.04221 \\
(-0.15002)\end{array}$ \\
\hline INC & $\begin{array}{c}0.06324 \\
(3.3058)^{*}\end{array}$ & $\begin{array}{c}0.07061 \\
(0.85560)\end{array}$ & $\begin{array}{c}0.02566 \\
(0.23985)\end{array}$ \\
\hline$D^{1}$ & $\begin{array}{c}-0.01245 \\
(-0.64836)\end{array}$ & $\begin{array}{c}-0.07309 \\
(-0.24503)\end{array}$ & $\begin{array}{l}-0.05058 \\
(-0.18442)\end{array}$ \\
\hline$D^{2}$ & $\begin{array}{c}0.08942 \\
(0.50242)\end{array}$ & $\begin{array}{r}-0.03094 \\
(-1.1327)\end{array}$ & $\begin{array}{c}-0.02329 \\
(-0.77706)\end{array}$ \\
\hline$D^{3}$ & $\begin{array}{l}-0.01213 \\
(-0.55548)\end{array}$ & $\begin{array}{r}-0.03869 \\
(-1.2994)\end{array}$ & $\begin{array}{c}-0.07016 \\
(-0.37346)\end{array}$ \\
\hline$R^{2}$ & 0.55 & 0.33 & 0.17 \\
\hline $\bar{F}$ & $7.357^{*}$ & $3.033^{*}$ & 1.211 \\
\hline$\overline{S E E}$ & 0.3833 & 0.67024 & 0.60208 \\
\hline $\mathbf{N}$ & 58 & 58 & 58 \\
\hline
\end{tabular}


TADLE XIII

REGRESSION RESULTS FOR MODEL TWO:

SOCIAL SERVICES INDUSTRIES

( $t$-ratios in parentheses)

\begin{tabular}{|c|c|c|c|}
\hline & 1960 & 1970 & 1980 \\
\hline MANF & $\begin{array}{l}\frac{B}{-0.03169} \\
(-1.8331)\end{array}$ & 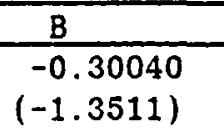 & 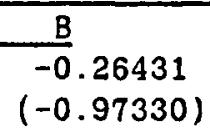 \\
\hline HITN & $\begin{array}{c}-0.14073 \\
(-2.2224)^{*}\end{array}$ & $\begin{array}{r}-0.13530 \\
(-1.1757)\end{array}$ & $\begin{array}{r}-0.03106 \\
(-0.2634)\end{array}$ \\
\hline POPUL & $\begin{array}{r}0.08728 \\
(3.5699)\end{array}$ & $\begin{array}{c}0.01368 \\
(4.1715)^{*}\end{array}$ & $\begin{array}{c}0.01055 \\
(2.3158)^{*}\end{array}$ \\
\hline$\overline{A G E}$ & $\begin{array}{c}0.30730 \\
(4.3075)^{*}\end{array}$ & $\begin{array}{c}0.32214 \\
(2.2703)^{*}\end{array}$ & $\begin{array}{c}0.35930 \\
(2.1492)^{*}\end{array}$ \\
\hline INC & $\begin{array}{r}0.09841 \\
(1.0905)\end{array}$ & $\begin{array}{c}0.01006 \\
(0.27544)\end{array}$ & $\begin{array}{c}-0.04358 \\
(-0.90955)\end{array}$ \\
\hline $\mathrm{D}^{1}$ & $\begin{array}{c}0.06733 \\
(0.74302)\end{array}$ & $\begin{array}{c}0.06850 \\
(0.51901)\end{array}$ & $\begin{array}{r}0.02325 \\
(1.4183)\end{array}$ \\
\hline$D^{2}$ & $\begin{array}{c}0.01371 \\
(0.16330)\end{array}$ & $\begin{array}{c}0.06602 \\
(0.54617)\end{array}$ & $\begin{array}{c}-0.06896 \\
(-0.41026)\end{array}$ \\
\hline$D^{3}$ & $\begin{array}{c}0.03021 \\
(0.29336)\end{array}$ & $\begin{array}{c}0.02764 \\
(0.20980)\end{array}$ & $\begin{array}{c}0.02265 \\
(0.10279)\end{array}$ \\
\hline $\mathrm{R}^{2}$ & 0.49 & 0.40 & 0.28 \\
\hline F & $5.881 *$ & $4.077^{*}$ & $2.439^{*}$ \\
\hline$\overline{\mathrm{SEE}}$ & 0.18081 & 0.29659 & 0.36505 \\
\hline $\mathbf{N}$ & 58 & 58 & 58 \\
\hline
\end{tabular}

* Significant at .05 
The cross-sectional equations for business services in 1980 indicate an interesting pattern of positive association with $D^{1}$ and $\mathrm{D}^{2}$, having a statistical significance at .05 percent. This pattern indicates significant relative employment growth in the business services in both SMSA (dummy 1) and non-SMSA-adjacent (dummy 2) counties, which may be due to business services being faced by two levels of demand. First, some business services are directed primarily at final consumers and are, therefore, sensitive to location; thus, as the SMSA and non-SMSA-adjacent counties' economies grow, business services will tend to grow in response to the increasing numbers of final consumers (see Table XVI). The second level of demand involves the existence of business firm markets, which, because of their business orientation, tend to favor locations in non-SMSA-adjacent counties in response to the intermediate demand between firms. As Table XVI reveals, employment in business services in 1960 and 1970 experienced no relative growth differentials across geographic areas (i.e., SHSA, non-SiHSA-adjacent, and non-SHSAnonadjacent counties). By 1980, however, business services experienced relative growth favoring locations in the SMSA and nonSMSA-adjacent counties, as indicated by the coefficient with statistical significance at a level of .05 . In fact, business services growth in the SMSA and non-SMSA-adjacent counties in 1980 was expected, due largely to technological changes favoring the spread of business services across geographic boundaries in order to capture business firm and final consumer markets. Further, these results conform to theories proposed by a number of writers who have stated 
that business services are growing in suburban areas (e.g., Erickson, 1983; Lewis, 1983).

TABLE XIV

REGRESSION RESULTS FOR MODEL TWO:

BUSINESS SERVICE INDUSTRIES

( $t$-ratios in parentheses)

\begin{tabular}{|c|c|c|c|}
\hline & 1960 & 1970 & 1980 \\
\hline MANF & $\begin{array}{l}-\frac{B}{-0.05191} \\
(-2.2436)^{*}\end{array}$ & 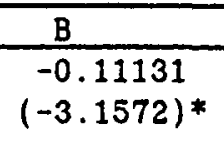 & $\begin{array}{l}\frac{\mathrm{B}}{-0.01303} \\
(-0.49536)\end{array}$ \\
\hline$\overline{H I T N}$ & $\begin{array}{l}-0.09938 \\
(-1.1725)\end{array}$ & $\begin{array}{c}-0.12480 \\
(-0.94433)\end{array}$ & $\begin{array}{c}-0.15686 \\
(-0.29052)\end{array}$ \\
\hline POPUL & $\begin{array}{c}0.01255 \\
(3.8355)^{*}\end{array}$ & $\begin{array}{c}0.01377 \\
(3.6562)^{*}\end{array}$ & $\begin{array}{c}0.05143 \\
(2.7891)^{*}\end{array}$ \\
\hline$\overline{\mathrm{AGE}}$ & $\begin{array}{c}0.26076 \\
(2.7307)^{*}\end{array}$ & $\begin{array}{c}0.36188 \\
(2.2210)^{*}\end{array}$ & $\begin{array}{c}-0.43363 \\
(-0.56447)\end{array}$ \\
\hline$\overline{\text { INC }}$ & $\begin{array}{c}0.01037 \\
(0.85813)\end{array}$ & $\begin{array}{c}0.04908 \\
(1.1705)\end{array}$ & $\begin{array}{r}-0.19060 \\
(-1.6366)\end{array}$ \\
\hline$D^{1}$ & $\begin{array}{c}0.03598 \\
(0.29660)\end{array}$ & $\begin{array}{r}-0.01691 \\
(-1.1155)\end{array}$ & $\begin{array}{c}0.14624 \\
(2.1490)^{*}\end{array}$ \\
\hline$D^{2}$ & $\begin{array}{r}-0.01579 \\
(-1.4058)\end{array}$ & $\begin{array}{c}-0.08003 \\
(-0.57655)\end{array}$ & $\begin{array}{c}0.17600 \\
(2.6665)^{*}\end{array}$ \\
\hline$D^{3}$ & $\begin{array}{r}-0.01449 \\
(-1.0517)\end{array}$ & $\begin{array}{l}-0.01621 \\
(-0.10713)\end{array}$ & $\begin{array}{r}0.15326 \\
(1.8322)\end{array}$ \\
\hline $\mathrm{R}^{2}$ & 0.60 & 0.42 & 0.23 \\
\hline F & $8.734^{*}$ & $4.448^{*}$ & $1.846^{*}$ \\
\hline$\overline{\text { SEE }}$ & 0.2420 .3 & 0.34057 & 0.16428 \\
\hline $\mathrm{N}$ & 58 & 58 & 58 \\
\hline
\end{tabular}

* Significant at .05 
From the empirical results, it seems possible that the patterns of decentralization in the service sector might not necessarily follow the pattern established by the decentralization of manufacturing, at least not in California. This might be explained by noting that the service sector differs from manufacturing in that, with the latter, decentralization occurs by relocating the manufacturing facilities entirely away from the core to other SMSA, non-SMSA-adjacent, and nonSMSA-nonadjacent counties; while service industries, being smaller in size and characteristically client- and firm-oriented, are able to provide services in the outlying areas by simply opening branch offices, thereby only partially relocating away from the core. This might be the reason for the lack of significant differences in the coefficients for the three dummy variables for the three time periods in regard to the relative locations of growth in distributive, social, and personal service industries.

THE LOCATION AND GROWTH OF THE AGGREGATE SERVICE INDUSTRIES OVER TIME

The regression output presented in Table XV compares trends across the periods 1960,1970 , and 1980 regarding the locations of the aggregate service industries. The three dummy variables for the period 1960 indicate the expected sign, but they lack statistical significance. However, the high employment growth experienced in the service sector in 1970 began emerging in the SMSA counties, as was indicated by the statistical significance (at .05 percent) in dummy variable one. Nonetheless, the employment in the SMSA counties relative to that in non-SMSA-adjacent counties for the aggregate 
service industries in the period 1970 shows a negative sign. This may be due to the fact that service employment growth in the SMSA counties in 1970 declined relative to service industry growth in non-SMSAadjacent counties in 1980 (which was indicated with a statistical significance of .05 percent). As seen in the tables, it has a negative sign, while dummy variable one (the SuSA counties) has a positive association, even though it is an insignificant one. Accordingly, one might expect from this positive association that in 1980, service sector employment as a whole experienced a decline in employment in the non-SMSA-adjacent counties. This being the case, one would then expect service sector employment, relative to locational growth differentials among SMSA, non-SMSA-adjacent, and non-SMSA-nonadjacent counties to begin diminishing over time.

The instability of the coefficient for the dumny variable may also be the result of the service industries having followed other regional economic activity, therefore experiencing a lag effect determining the pattern of growth and/or stability in any one location over time. 
TABLE XV

REGRESSION RESULTS FOR MODEL TWO: SERVICE INDUSTRIES OVER TIME (t-ratios in parentheses)

\begin{tabular}{|c|c|c|c|}
\hline & 1960 & 1970 & 1980 \\
\hline MANF & 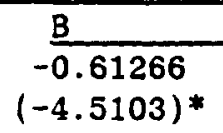 & 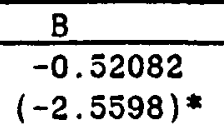 & $\begin{array}{c}\frac{B}{-0.08293} \\
(-0.46647)\end{array}$ \\
\hline HITN & $\begin{array}{c}-0.25742 \\
(-0.51727)\end{array}$ & $\begin{array}{c}-1.0876 \\
(-1.1475)\end{array}$ & $\begin{array}{c}-0.95965 \\
(-2.6366) *\end{array}$ \\
\hline POPUL & $\begin{array}{c}0.05712 \\
(2.9734)^{*}\end{array}$ & $\begin{array}{c}0.05403 \\
(2.5414)^{*}\end{array}$ & $\begin{array}{r}0.02396 \\
(1.6207)\end{array}$ \\
\hline$\overline{\text { AGE }}$ & $\begin{array}{c}1.3598 \\
(2.4255)^{*}\end{array}$ & $\begin{array}{c}0.77358 \\
(0.87238)\end{array}$ & $\begin{array}{c}0.25047 \\
(0.49069)\end{array}$ \\
\hline INC & $\begin{array}{c}0.23052 \\
(3.2507) *\end{array}$ & $\begin{array}{c}0.20507 \\
(0.80563)\end{array}$ & $\begin{array}{r}-0.23422 \\
(-1.4378)\end{array}$ \\
\hline $\mathrm{D}^{1}$ & $\begin{array}{c}-0.04355 \\
(-0.61151)\end{array}$ & $\begin{array}{c}-0.17233^{*} \\
(-2.0459)^{*}\end{array}$ & $\begin{array}{c}0.28794 \\
(0.57046)\end{array}$ \\
\hline$D^{2}$ & $\begin{array}{c}0.02800 \\
(0.42442)\end{array}$ & $\begin{array}{r}-0.09998 \\
(-1.1353)\end{array}$ & $\begin{array}{c}-0.11482 \\
(-2.0818)^{*}\end{array}$ \\
\hline$D^{3}$ & $\begin{array}{c}0.04394 \\
(0.54297)\end{array}$ & $\begin{array}{r}-0.03094 \\
(-0.3104)\end{array}$ & $\begin{array}{c}-0.06484 \\
(-0.94391)\end{array}$ \\
\hline $\mathrm{R}^{2}$ & 0.58 & 0.31 & 0.32 \\
\hline F & $8.494^{*}$ & $2.764^{*}$ & $2.860^{*}$ \\
\hline$\overline{\mathrm{SEE}}$ & 0.14208 & 0.19741 & 0.11080 \\
\hline $\mathrm{N}$ & 58 & 58 & 58 \\
\hline
\end{tabular}


Model One was developed to examine the relative employment growth of the four service industries in the regional economy. The crosssectional and time series pooled models are designed specifically to address patterns of estimates of the coefficlents in relation to the sectoral compositions. This approach can, therefore, be seen as an attempt to examine the hypothesized determinants of changes in the sectoral composition of the service industries.

The overall explanatory power of the equations in Model One and Model Two, as represented by the $R^{2}$ and $F$ statistics, in some instances is not high. These results, however, are comparable and in most instances superior to results obtained in similar research.

It should be noted that a model with a higher $\mathrm{R}^{2}$ is not necessarily better than one with a lower $R^{2}$. Rather the important point is how the research is designed, whether the coefficients have the right signs, and whether they make sense according to the specification (Maddala 1977).

Spatial auto correlation results when a systematic spatial pattern of correlation among the regression residuals exists. The effect of this correlation on the analysis would be twofold:

1) It would make the estimates of the regression coefficients less reliable;

2) It would lead to underestimation of the variance of the regression coefficients.

The end result of the effects of spatial auto correlation is that one would be mistakenly led to conclude that statistically significance exists when in fact it does not. 
Concerns about spatial auto correlation are lessened in this research given the performance of the spatial dummy variables in Model Two. With several exceptions, we find that the coefficients associated with these dumy variables are not statistically significant. Had these coefficients been found to exhibit a greater degree of significance, further tests for spatial auto correlation (Cliff and Ord, 1981) would have been warranted. 
THE CHOW TEST

The Chow test is designed to test the stability of the coefficient of the sub-model against the time-series pooled model for each of the four service industries. There are twelve models representing the distributive, personal, business, and social services, one each for the perlods 1960, 1970, and 1980. There are also four time-series pooled models for the four service industries between 1960 and 1980 . The independent variable employed in all periods is the same. The units of observation for the cross-section is $\mathrm{N}=58$, and for the pooled model is $\mathrm{N}=174$ (3x58). Thus, the Chow test is formulated as follows:

* The unrestricted distributive service industry cross-sectional model for each of the time periods (1960, 1970, and 1980) against the restricted time-series pooled model for the distributive services.

* The unrestricted personal service industry cross-sectional model for each of the time periods (1960, 1970, and 1980) against the restricted time-series pooled model for the personal services.

* The unrestricted business service industry cross-sectional model for each of the time periods (1960, 1970, and 1980) against the restricted time-serles pooled model for the business services.

* The unrestricted social service industry cross-sectional model for each of the time periods $(1960,1970$, and 1980) against the restricted time-series pooled model for the social services.

The general formula to implement the chow test is as follows: 
TABLE XVI

RESULTS OF THE CHOW TEST

\begin{tabular}{llll}
\hline & & & \\
\hline Sectors & URSS & RRSS & F \\
\hline Distributive & 3.35939 & 3.7282 & 1.79 \\
\hline Personal & 0.49423 & .51336 & .63 \\
\hline Business & 0.20319 & .23100 & $2.24^{*}$ \\
\hline Social & 0.15101 & .17662 & $2.77^{*}$ \\
\hline & 9 & & \\
\hline
\end{tabular}

$F=$ value Significant at $.05^{*}$ $N=174$

The Chow Test in Table XVI, developed for the distributive and personal service industries is found insignificant F-ratio, which indicates that the coefficients are stable over time. But the business service and social service industries test for stability of the coefficient indicates instability over time. This may be due to the fact that over time consumers demand change, and that new kinds of operations emerge from the industrial variables as well. These kinds of continuous industrial and market changes, which might be referred to as dynamism in the variables, tends to change the coefficient over 
As the economy produces differentiated and complex commodities, consumers demand both more of these products and more services in order to maintain them. The changes in demographic characteristics, such as an increase in the percentage of the population in a given area which is 65 years and over influences the service industries in that area to change their marketing approaches. As a result of the continuous change of the factors that determine growth of the service industries, firms in the service industry will also undergo a similar change over time. 
CHAPTER XI

\section{CONCLUSIONS AND RECOMMENDATIONS}

The purpose of this research has been to focus attention on the growth of eaployment in the four segments of the service sector (distributive, personal, business, and social) in the regional economy of the state of California. Its intention has been to provide a wideranging account of the factors most prominently influencing recent structural changes in employment in the four service industries and the pattern of the geographical distribution of this employment in California between 1960 and 1980 .

The regression cross-sectional and time-series pooled models that were developed in the course of this study to better understand these structural changes indicate that all service industries have one thing in common: employment in the service sector continues to grow, largely because of a continuing strong demand for services. Factors including income, industrial and demographic variables, and intermediate demand among the various service industries generate a multiplier effect. The models presented in this study are of interest insofar as they document the variety of levels of influence that the independent variables have on the disaggregation of the service sector. The study's findings point to several prominent conclusions:

Both population and income influenced employment growth in the distributive services in California during the period under study (1960-1980). 
The relative growth in employment in the personal service industries resulted from increases in income and in the number of elderly (over 65) in the state.

Business service employment is accelerating due to the combined factors of age, population, and income.

Rising employment in the social services is due primarily to increases in the age, population, and income variables in the state.

The results of the regression analyses brought out several important facts pertaining to the above conclusions, for example, that the relative growth of the various service industries taken collectively is dependent on income. However, this is only a partial explanation of the structural changes in employment that favor increases in the service sector as the economy advances (see Clark. 1940). When the analysis is done by sector, as it was here, then income is clearly seen to be only one of several factors influencing the structural changes. For example, population pressures in California contribute significantly to the growth of the distributive, business, and social services, and the age variable influences the rapid expansion of employment in the social services (particularly health services) and the business services.

An attempt has been made in this study to formulate a systematic framework for assessing the relationships among the four segments of the service sector, and between each of them and the manufacturing sector. The results of the analysis indicate the existence of complementary and substitution relationships among the four service Industries and between each of them and manufacturing. Findings such as these should provide regional planners with a means of identifying 
industries whose characteristics are most conducive to the growth of other industries.

The model that was developed to study the regional distribution of the four service industries geographically (i.e., relative to SMSA, non-SMSA-adjacent, and non-SMSA-nonadjacent, county locations) indicates different patterns of growth for each of the geographical zones. The study convincingly confirms trends noted by other researchers (Erickson, 1983; Lewis, 1983), specifically, that business service industries are growing in SMSA and non-SMSA-adjacent counties in California. The locational growth pattern of the service industries collectively in 1970 indicates that employment is growing in SMSA counties relative to the other two zones, and that this growth extends toward non-SMSA-adjacent counties by 1980 , when it was higher there than in either SMSA or non-SMSA-nonadjacent counties.

In general, the results for individual service industries show parallel tendencies, i.e., the distribution of services without any noticeable difference for any of the geographic zones. The implication of this is that those factors which attract growth in services employment might not exhibit significant differences from one geographic zone to another. In other words, for the most part, shares are explained by "conventional" variables and do not show spatially significant patterns of variation.

The overall result of the analysis indicates that the relatively large volume of employment in the service sector in California is due to strong market demand. Thus, it would be a mistake to generalize that such growth is due to the service sector's being simply a beneficiary of the manufacturing industries alone. Such assertions 
are based on the crudest of analyses. In any event, the expansion of both final and intermediate demand for services generally benefits labor. Since the service industries are by in large labor-intensive, it is unlikely that other modes of production (e.g., advanced technology) will substitute for it. The underlying reason for this is that the potential for the substitution of physical capital for labor is 1 imited at best in the forseeable future, since by their very nature the production, maintenance, and delivery of services requires personal contact. Even the development of new technology for office use might not reduce the quantity of labor employed, while at the same time, the employment of advanced technology combined with labor will improve the efficiency of labor in the service sector in the long run. Judging by the past trends, the relative growth of employment in the service sector will continue. This being the case, it is important to implement appropriate training policies in order to enhance the employability of individuals who could not otherwise adapt to employment in the service sector. While not every one may agree with the impact on the labor force, the challenge calls for a much better understanding of the functioning of the current labor markets and a review of public sector intervention. Thus, current structural changes which favor the growth of employment in the service industries require a flowering of new and innovative ideas. These, however, are more likely to lie in the real of the manpower structure of the regional economy.

In the course of executing this research, a number of issues were raised and new research was noted for the future. This research has focused on structural shifts within the service sectors. As a result, 
its conclusions pertain to changes in the sectoral composition of employment rather than the absolute growth or decline in service sector employment. Thus, much could be gained from additional research on absolute employment change in the service sectors.

Other issues suggested to explore further are as follows:

1. What is happening in the U.S. Metropolitan economy in the light of the declining employment in the manufacturing industries.

2. Distinguish producer services from final services and determine the importance of each in the growth in employment.

3. Examine sectoral differentials in the rates of change in wages and rates of change in labor quality.

4. Examine how regulations have influenced services and how they may be expected to influence them in the future. 


\section{BIBLIOGRAPHY}

Bauer. P.T., and Yamey, B.S. "Economic Progress and Occupational Distribution. Economic Journal 61 (1951) 741-755.

Baumal. William J. "Macroeconomics of Unbalanced Growth: The Anatomy of Urban Crisis." American Economic Review (1968): 116-426.

Beam, Louis $H$. Income and Wealth: Vol. 8, International Industrialization and Per Capital Income. New York, 1946

Bearse. Peter J. On the Intra Regional Diffusion of Business Service Activity." Regional Studies (1978): 12, 562-578.

Bell. Daniel. The Coming of the Post-Industrial Society. New York: Basic Book, 1973.

Beyers, William B.. Alvine. Michael, and Johnsen, Erik G. The Service Economy: Export of Services in the Central Puget Sound Region, Seattle, Washington. April 1985.

Black, J. Thomas. The Prospective City: Economic, Population, Energy and Environmental Developments. Cambridge, MA: MIT Press, 1980.

Bowers. Norman. "Have Employment Patterns in Recessions Changed?" Konthly Labor Review 104 (February 1981) 15-24.

Brock, E. William. "Now the Invisibles Run Into Barriers." International Management 5 (1983) $1-5$.

Browne, Lynne. "Structural Change and Dislocated Workers." New England Economic Review (1985).

Burns, Arthur. "Progress Toward Economic Stability." American Economic Review 6 (March 1960): 6-7.

Carlino, G. From Centralization to Decentralization: Economic Act 1vity Spreads Out. Philadelphia: Federal Reserve Bank of Philadelphia, May/June 1982.

Casette, Emilio, and Leslie, J.K. Differential Rates of Growth in Urban Service Employment. Papers and Proceedings of the Regional Science Association 5 (1970) 130-147.

Clark, Colin. The Conditions of Economic Progress, New York: Yacmillan. 1940 . 
Clark, J.M. Strategic Factors in Business Cycles. New York: Harper and Row, 1934.

Cliff, A.D., and Ord, J.K. Special Process Models and Applications. Pion, 1981

Cohen, R. "The Changing Transaction Economy and Its Spatial Implication" Ekitics 46 (1979): 7-15.

Conroy, Michael E. "The Optional Diversification of Regional Industrial structures. Paper presented at the 1972 meeting of the Econometric Suciety. Toronto, Canada, December 28, 1972.

Cooke, T.W.. Causality Reconsidered: Journal of Urban Economics. 5, (1978) 538-42.

Corey, K.E. Transactional Forces and the Metropolis. Ekistics, 297 (1982) $416-243$.

Daniels. P.W., "Business Service Office in British Provincial Cities: Location and Control." Environment and Planning 15, (1983)

Daniels, P.W., "Service Industries: Supporting role of Center State." Area 15. (1983)

Daniels, P.W., Service Industries: Growth and Location. Cambridge, England: Cambridge University Press. 1982.

Dunn, Edgar S. The Development of the U.S. Urban System. Baltimore. The Johns Hopkins University Press, 1980.

Economic Growth and the Rise of Service-Employment National Bureau of Economic Research, 1980.

Economic Report of the Governor of California. Sacramento. CA: Office of State Printing, 1983.

Ehrenhalt, Samuel $M$. On Subcommittee hearing on International Trade. No. -2058 and S. $2051,1982$.

Erickson, Rodney A. "The Evolution of the Suburban Space Economy." Urban Geography 4, (1983) 195-121.

Feldman, Robert A. and Proctor, Allen J. Federal Reserve Bank of New York, Quarterly Review - (Spring 1983) 30-36.

The Financial Times, London, England, October 19, (1983)

F1sher, Allan G. The-Class of Progress and Security. New York. Macmillan, 1930. 
Fuchs, Victor R. Economic Growth and the Rise of Service-Employment. Washington, D.C.: National Bureau of Economic Research, 1980.

Fuchs, Victor $R$. "The First Service Economy." The Public Interest. 2 (1965): $7-17$.

Fuchs, Victor $R$. The Growing Importance of the Service Industries. Washington, D.C.; National Bureau of Ecoromic Research, 1966.

Fuchs, Victor R. "The Service Econony." Washington, D.C.: National Bureau of Economic Research, 1968.

Fusfeld. D.R. "Population Growth and Employment in Service Industries." The Southern Economic Journal, 35, (1968) 73-77.

Gengler, Michele, J., and Ternsins, Richard J. "Robots are Coming to Work in America," Business 32 (1983)

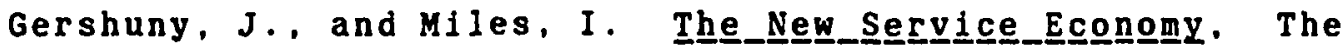
Transformation of Employment in Industrial Societies. New York, Praeger Publishers, 1983.

Ginzberg. El1, "The Economic Consequences of Automation." Chapter 3 in Manpower Agenda for America, McGraw-HI1l: New York, 1968

Gober, Patricia, and Behrs, Michelle. "Central Cities and Suburbs as Distinct Place Types: Myth or Fact?" Economic Geography 15. (1982): $371-383$

Gottman, Jean. The Coming of the Transactional City. University of Maryland. Institute of Urban Studies. 1983.

Grubb, W.N. "The Flight of the Suburbs of Population and Employment, 1960-1970." Journal of Urban Economics, 11 (1982): 348-67.

Gruenstein, John M.L.. and Guerra, Sally. Can Services Sustain a Regional Economy? Philadelphia. Federal Reserve Book of Philadelphia, 1981.

Hewitt, Garth. "Foreign Trade." International Management, 8 (1983) $1-4$

Hill. T.P. "On Goods and Services" Review of Income and Wealth 23 (1977): 315-38.

Hirschman, A.0. The Strategy of Economic Development. New Haven, CT: 1958. 
Hooper, Dianna and Bournne. The Changing Economic Bas is of Canadian Urban Growth. Toronto: Center for Urban and Community Studies. University of Toronto, 1983.

Isard, Walter. Intraduction to Regional Science. Englewood Cliffs, New Jersey: Prentice-Hall, 1969.

Jonscher. J. Charles. "A Productivity Revolution in the Service Sector." Business Week, (September 1983): 106-108.

Kahley, William J., and Tapp, Gary W. "Structural Changes in Southeastern States: The Road Ahead," Economic Review. Federal Reserve Bank of Atlanta, October 1983.

Katouzian, M.A. "The Development of the Service Sector: A New Approach." Oxford Economic Paper, 22 (1970) 362-381.

Kellerman, A., and Krakover, S. Multi Sectoral Urban Growth in Space and Time: An Empirical Approach. Growth and Change, 20 (April 1986) 117-130.

Kellerman, Aharon. "The Evolution of Service Economics: A Geographical Perspective." The Professional Geographer, 2 (1985) 134-143.

Kindleberger, J., The Distribution of Resource Allocation in the Metropolitan Regions: Economic Geography, 10 (1956) 183-190.

Knight, Richard V., Employment Expansion and Metropolitan Trade. New York: Praeger Publishers, 1973.

Kutscher, Ronald E.. and Mark, Jerome A., "The Service-Producing Sector: Some Common Perceptions Reviewed." Monthly Labor Review 106, (April 1983): p.21-24.

Kuznets, Simon "Quantitative Aspects of the Economic Growth of Nations. Part III. Industrial Distribution of Income and Labor Force by States, United States, 1919-1921 to 1955." Economic Development and Cultural Change. 6 (1958)

Kuznets, Simon, The Dialogues of Service Industries. New York: Strategic Planning Division, Citicorp and Conservation of Human Resources, Columbia University, 1980.

Lawrence, and Broner, "Specialization in Service Industry Employment as a State Pollcy." Growth and Change (October 1979), 18-23.

Leontief, Wassily. The Future of the World Economy. Oxford: Oxford University Press, 1977. 
Leslie, J.K., and Jaffrey, Emilio C., Differential Rates of Growth in Urban Service Employment. Papers and Proceedings of the Regional Science Association, 1970.

Leveson. Irving F., Commission on International Trade Policy and Trade-related Matters. Position Paper on Liberalization of Trade in Services. U.S. Government Document $\$ 103 / 34$. Washington. D.C.: U.S. Government Printing office, 1982.

Leviton, Sar A., and Johnson, Clifford M. "The Future of Work: Does it Belong to Us or to the Robots?" Monthly Labor Review, 105 (1982):

Lewis, J., and Pierce, F., "The Galactic Metropolis," Beyond the Urban Fringe: Land Use Issues of Non-Metropolitan America edited by Rutherford H. Platt and George Macinko, 23-49. Minneapolis: University of Minnesota Press, 1983.

Lewis, Russell. The New Service Soeigty, London: Longman Press, 1973.

Linder, Stefan B. The Harried Leisure Class New York: Columbia University Press, 1970.

Maddala, G.S., Econometrics: McGraw-Hill, New York, 1977.

Marshall, J.N. "Linkages Between Manufacturing Industries and Business Services." Environment and Planning 14 (1985): 1523-1540.

HcCarthy, Kevin F., and Morrison, Peter A. "The Changing Demographic and Economic Structure of Nonmetropolitan Areas in the United States." 2 (1977).

Miernyk, William N. The Changing Structure of the Southern Economy. North Carolina: The Southern Growth Policies Doard, January 1977 .

Mills, E., Urban Density Functions, Urban Studies. 7, (1970) 5-20.

Morrill, Richard L. "Continuing Deconcentration Trends in Trade." Growth and Change 13 (1982).

Moskal. Brian. "Foundations of Employment: A Look at the FastestGrowing Service Industries." Industry Week, (June 10, 1985): 5760 .

Myerdal, G. Economic Theory and Underdeveloped Regions. London: 1957.

Nayelle. Thierry J., "The Rise of Advanced Services." Journal of American Planning 4 (Summer 1983). 
Organization for Economic Cooperation and Development, Regional Policies and the Service Sector, OECD, 1978

Oshima, Harry T. "Labor Force: Explosion and the Labor Intensive Sector in Asian Growth." Economic Development and Cultural Change 19 (1971): 161-183.

Palmer. John D. "Consumer Service Industry Exports: New Attitudes and Concepts Needed for a Neglected Sector." The Columbia Journal of World Business, 20, (1985).

Pascal, Anthony H., and Gurwitz, Aaron. Picking Winners: Industrial Strategies for Local Economic Development. Los Angeles, CA: The Rand Publication Series, March 1983 (Rl-2932 HUD/RC)

Personick, Valerie A. "The Job Outlook Through 1995: The Industry Output and Employment Projections". Monthly Labor Statistics. (November 1983): 30-35.

Polese, Mario. Regional Demand for Business Services and Interregional Service Flows in a Small Canadian Region. Papers of the Regional Science Association. 50 (1982).

Reich, Robert B. The Next American Frontier, New York: Time Books, 1983.

Sabolo, Yves. The Service Industries. Geneva, Switzerland: publications of the International Labor office, 1975.

Sapir. Andre. "Trade in Services: Policy Issues for the Eighties": Columbia Journal of World Business 1982.

The Service Economy. Washington, D.C. National Bureau of Economic Research, (1965).

Shelp. Ronald Kent. Beyond Industrialization: Ascendancy of the Global Service Economy. New York: Praeger Special Studies, 1981.

Singlemann, Joachim, and Browning, Harley L. "Industrial Transformation and Occupational Change in the U.S. 1960-70." Social Forces. 59 (1980) 245-263.

Singlemann, Joachim. From Agriculture to Services. Beverly Hills, CA: Sage Publication, 1978.

Sorrention, Constance. "Comparing Employment Shifts in Ten Industrialized Countries." Monthly Labor Review (October 1970) 3-7. 
Stanback. Thomas M., Jr., et al. Services: The New Economy. Montclair. NJ: 1981, Allanheld, Osmun and Co.

Stanback. Thomas M.. Jr. Understanding the Service Economy: Employment. Productivity, Location, Baltimore: The Johns Hopkins University Press, -1979 .

Steinner, D. "Causality and Intraurban Location." Journal of Urban Economics. 4 (1982): 69-79.

Stigler, George J. Trends in Employment In Service Industries. Princeton. NJ: Princeton University Press, 1956.

Tanny, Stephen. "Post Industrial Canada, An Econometric Modelling Approach." Journal of the Future. 10 (February 1978) 44-52.

Thompson, Wilbur R. A Preface to Urban Economics. Baltimore: Johns Hopkins Press, 1970.

Tiebout, C. The Community Economic Base Study. New York: Committee for Economic Development. (1962).

Toffler, Alvin. Previews and Premises New York: William Morrow and Company, Inc. 1983.

Toffler, Alvin. The Third Wave. New York: William Morrow and Company, Inc. 1980 .

Tulpule, A.H., "Toward an Integrated Model of Distribution of Service Employment in the Non-central Areas of Greater London." Oxford Economic Bulletin 30 (1966): 207-230.

U.S. Bureau of Census, County Business Pattern, Washington, D.C.. U. S. Department of Commerce, 1960, 1970, 1980.

U.S. Congress, Subcommittee on International Trade. Hearings on International Trade No. 2058 and S. 2051, 1982.

U.S. Department of Commerce. Bureau of Economic Analysis and Survey of Current Business, July 1978.

U.S. Department of Commerce, Bureau of Labor Statistics, June 1985.

U.S. Department of Housing and Urban Development. Changing Conditions in Large Metropolitan Areas. Washington, D.C.: U.S. Department of Housing and Urban Development, Office of Policy Development and Research. Urban Data Report, No. 1, 1980.

U.S. National Study on Trade In Services: A Submission by the U.S.G. to G.A.T.T., Washington, D.C.: Government Printing office, 1982. 
Urquhart, Michael. "The Employment Shift to Services: Where Did it Come From?" Monthly Labor Revlew. (June 1984).

Urquhart, Michael. "The Services Industry: Is it Recession Proof?" Monthly Labor Review. (October 1981) 12-17.

White, Kenneth J. "Shazam - An Econometrics Computer Program." University of British Columbia, Vancouver, B.C., Canada. (1978)

W1lliams, J.I. "Regional Inequality and the Process of National Development: A Description of the Patterns." Economic Development and Cultural Change. (1965): 13. 3-45. 
APPENDIX 


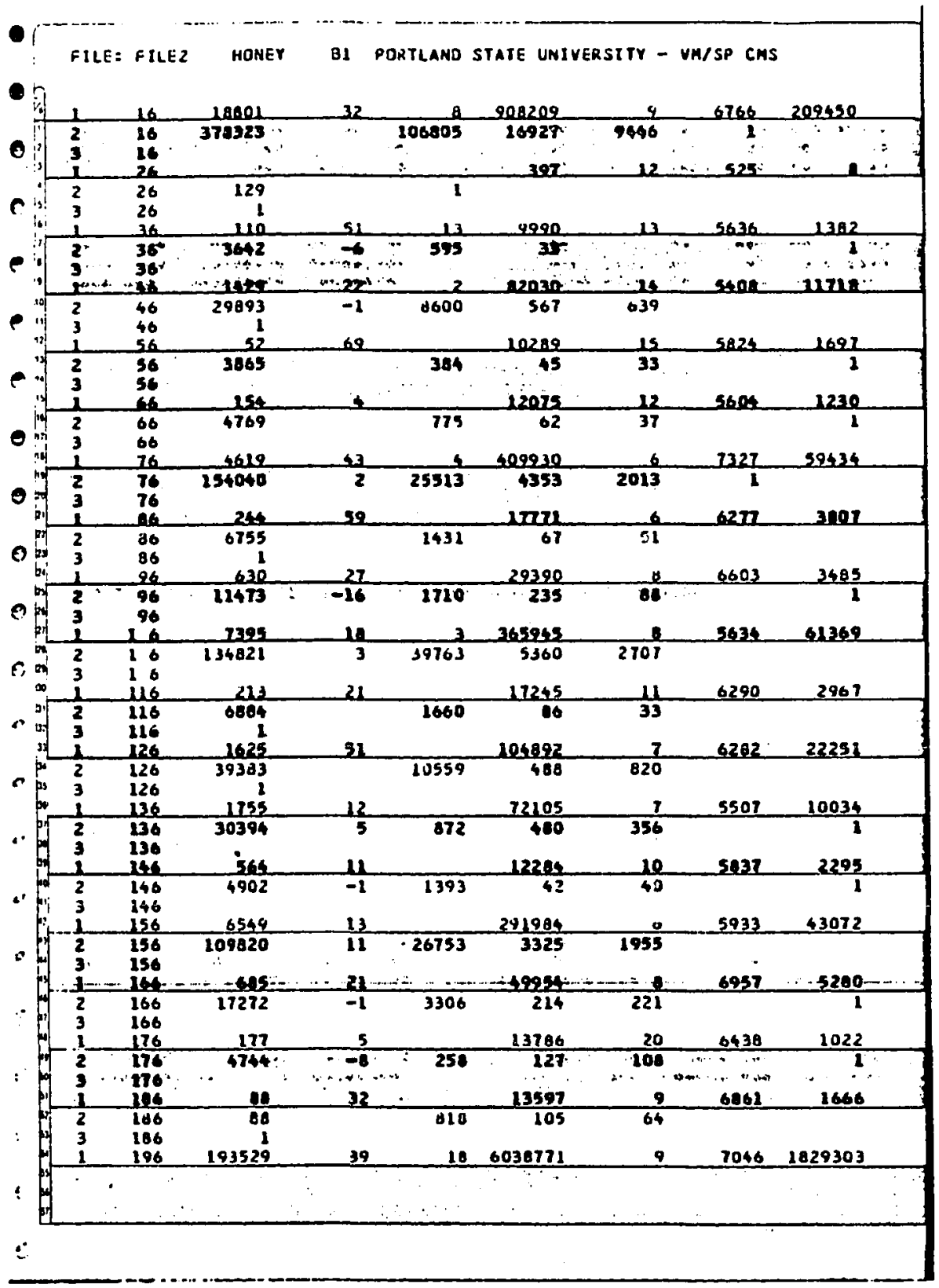




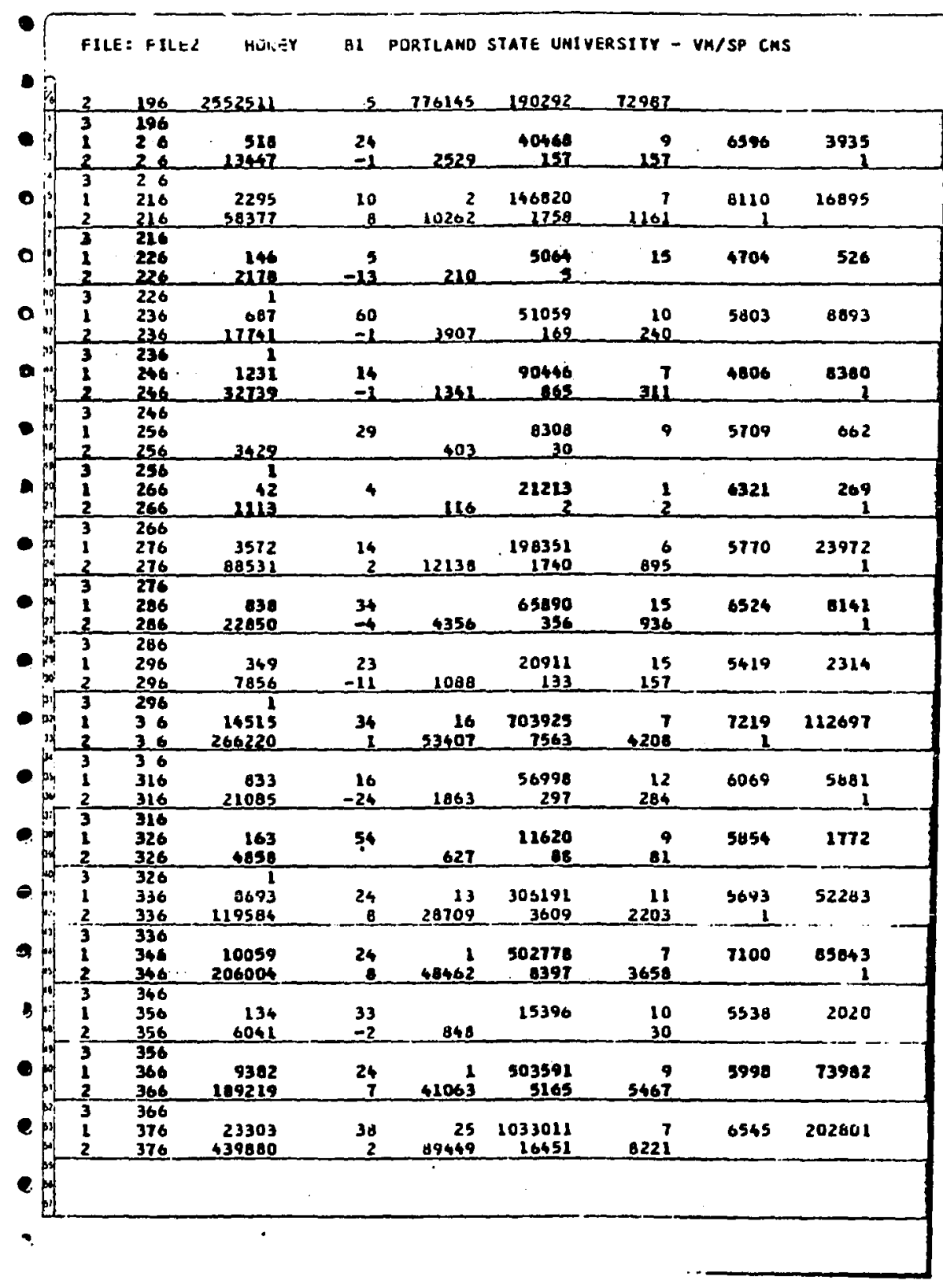




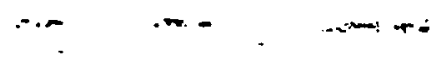

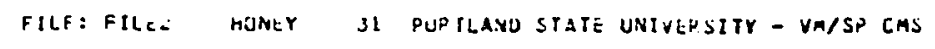

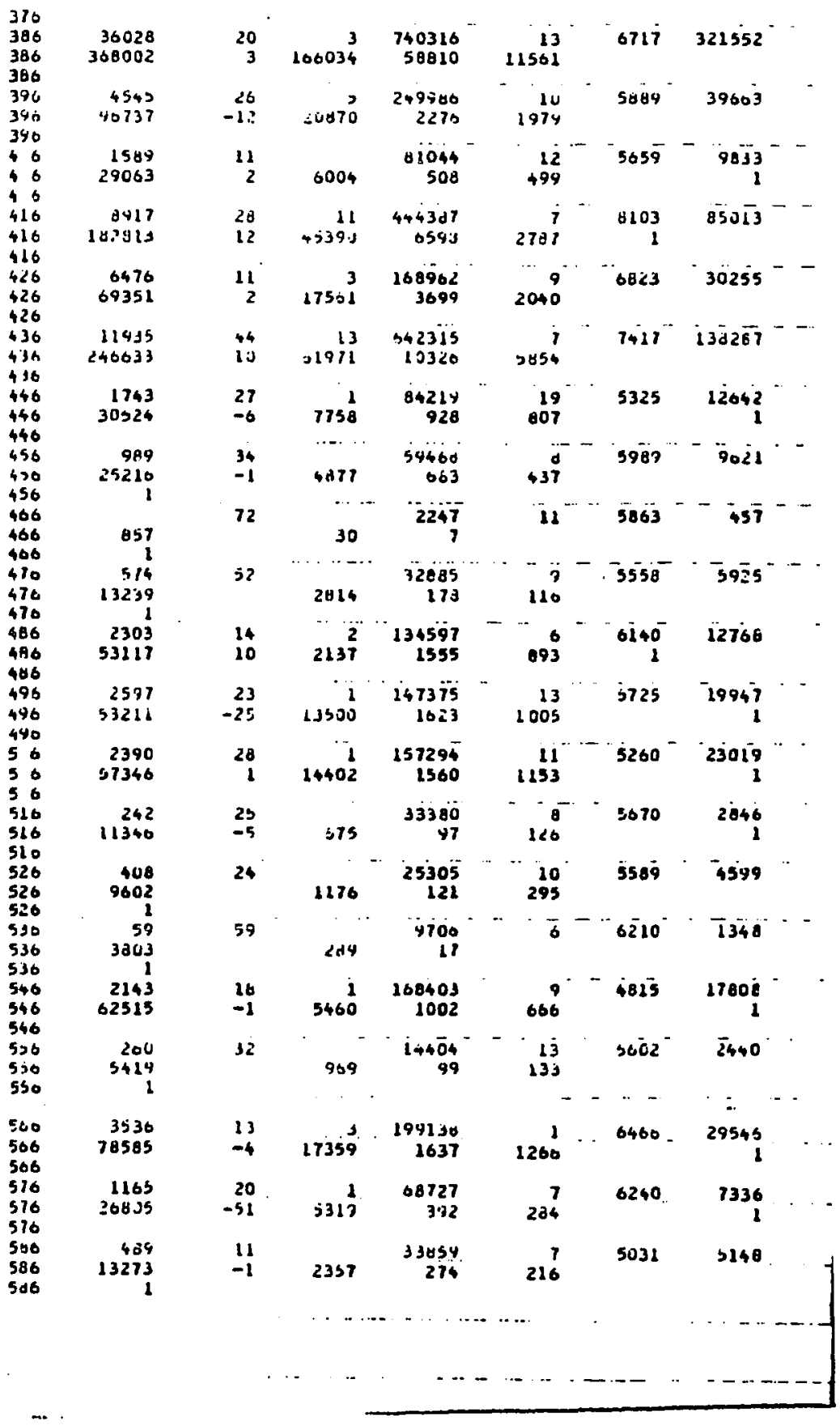




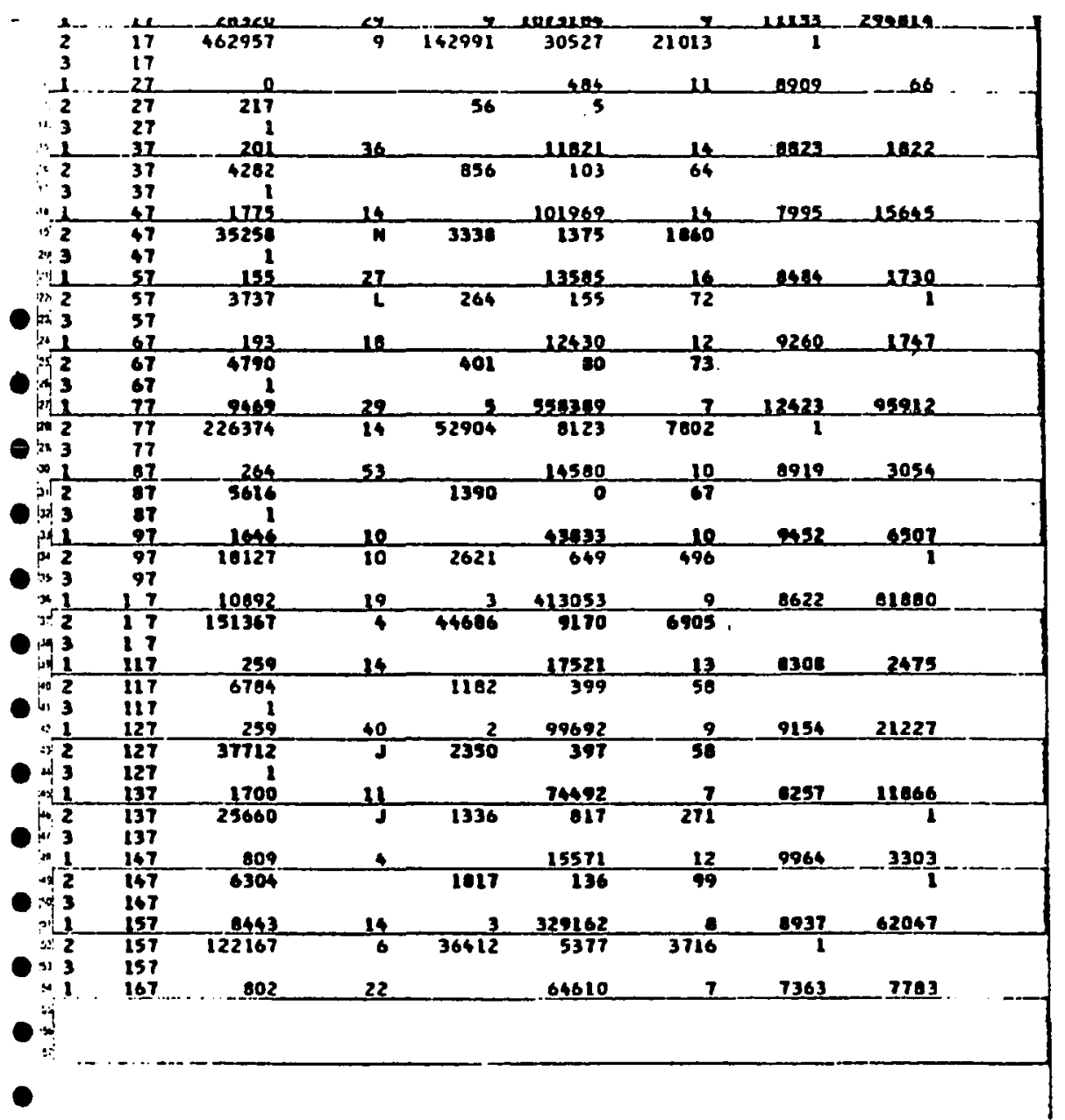




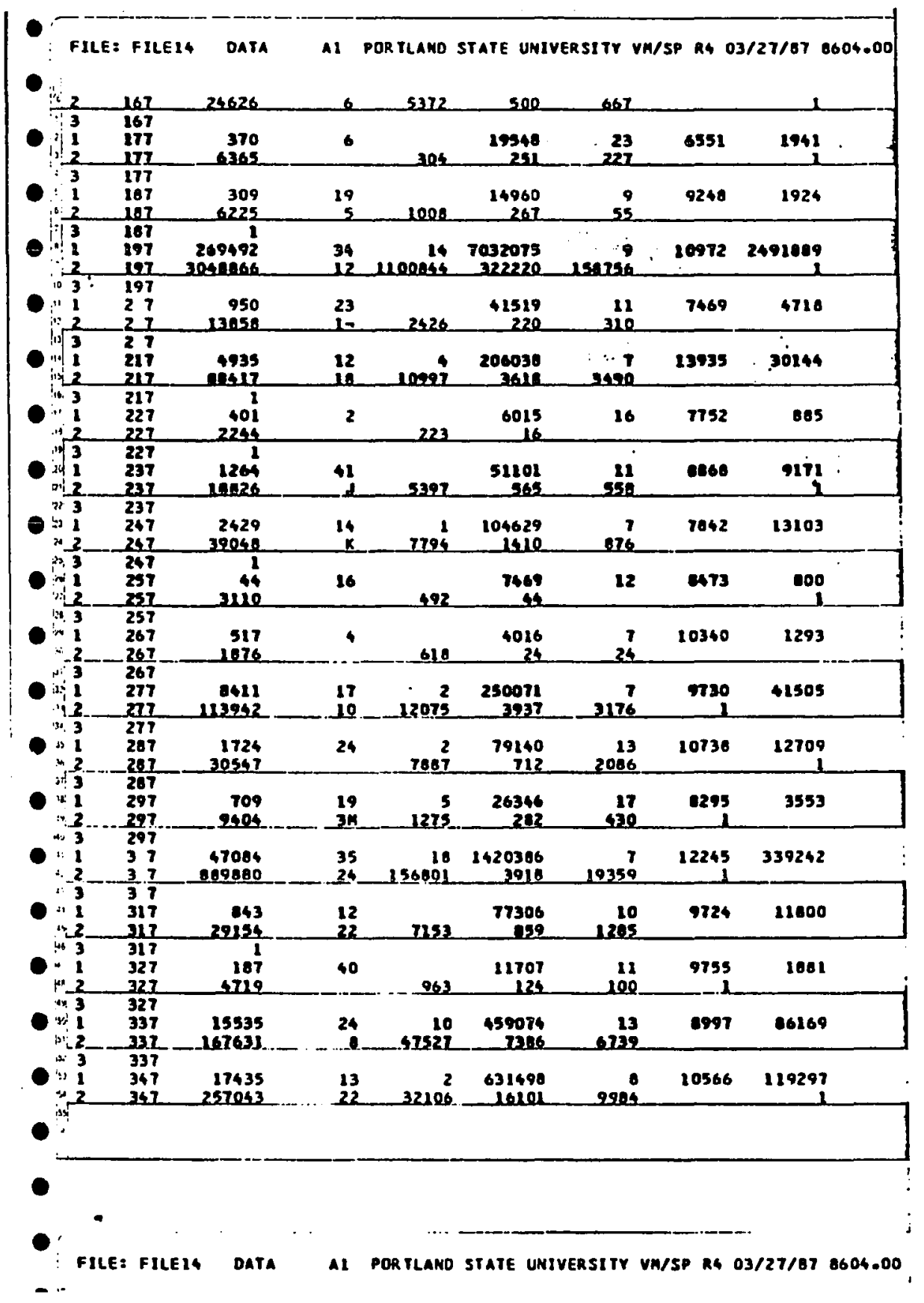


FILE: FILEIS DATA AI PORTLAND STATE UNIVERSITY UH/SP R4 03/27/87 0604.00

\begin{tabular}{|c|c|c|c|c|c|c|c|c|}
\hline $\begin{array}{l}1 \\
2 \\
3\end{array}$ & $\begin{array}{l}357 \\
357 \\
357\end{array}$ & $\begin{array}{r}190 \\
7220\end{array}$ & $\begin{array}{r}40 \\
2\end{array}$ & 2586 & $\begin{array}{r}14226 \\
119\end{array}$ & $\begin{array}{l}10 \\
89\end{array}$ & 0939 & 3754 \\
\hline $\begin{array}{l}1 \\
: 2 \\
13\end{array}$ & $\begin{array}{l}367 \\
367 \\
367\end{array}$ & $\begin{array}{r}16387 \\
256744\end{array}$ & $\begin{array}{r}26 \\
7\end{array}$ & $\begin{array}{r}71143^{7} \\
\text {. }\end{array}$ & $\begin{array}{r}684072 \\
10322\end{array}$ & $\begin{array}{r}10 \\
11587\end{array}$ & 9439 & 125333 \\
\hline $\begin{array}{r}1 \\
1.2 \\
4.3 \\
\end{array}$ & $\begin{array}{l}377 \\
377 \\
372\end{array}$ & $\begin{array}{r}44253 \\
590571\end{array}$ & $\begin{array}{r}13 \\
8\end{array}$ & $\begin{array}{r}12 \\
149517\end{array}$ & $\begin{array}{r}1357854 \\
29563\end{array}$ & $29029^{9}$ & 10133 & 290958 \\
\hline$?$ & $\begin{array}{l}387 \\
387 \\
3127\end{array}$ & $\begin{array}{r}44095 \\
151169\end{array}$ & $\begin{array}{r}15 \\
5\end{array}$ & 184512 & $\begin{array}{r}715674 \\
99924\end{array}$ & 21085 & 10503 & 401063 \\
\hline $\begin{array}{l}4,1 \\
4 \\
4\end{array}$ & $\begin{array}{l}397 \\
397 \\
397\end{array}$ & $\begin{array}{r}6978 \\
111367\end{array}$ & $\begin{array}{r}27 \\
7\end{array}$ & $\begin{array}{r}3 \\
34331\end{array}$ & $\begin{array}{r}290208 \\
4057\end{array}$ & $\begin{array}{r}10 \\
5203\end{array}$ & 902 & 59014 \\
\hline 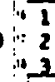 & $\begin{array}{r}17 \\
47 \\
+7 \\
\end{array}$ & $\begin{array}{r}3404 \\
38582\end{array}$ & 8 & 8174 & $\begin{array}{r}105690 \\
1137\end{array}$ & 1231 & 8738 & $\begin{array}{r}14702 \\
1\end{array}$ \\
\hline 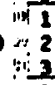 & $\begin{array}{r}417 \\
417 \\
417\end{array}$ & $\begin{array}{r}17911 \\
252507\end{array}$ & $\begin{array}{l}23 \\
29\end{array}$ & $\begin{array}{r}10 \\
09915\end{array}$ & $\begin{array}{r}536234 \\
17776\end{array}$ & 698 & $\begin{array}{r}13222 \\
\text { ( }\end{array}$ & 154195 \\
\hline $\begin{array}{l}\because 1 \\
\therefore 2\end{array}$ & $\begin{array}{r}427 \\
427 \\
427 \\
\end{array}$ & $\begin{array}{r}9865 \\
108310\end{array}$ & $\begin{array}{l}19 \\
13\end{array}$ & $\begin{array}{r}6 \\
31874\end{array}$ & $\begin{array}{r}264324 \\
6376\end{array}$ & 518 & 10455 & 60860 \\
\hline$\therefore 3$ & $\begin{array}{r}437 \\
437 \\
437 \\
\end{array}$ & $\begin{array}{r}27144 \\
440132\end{array}$ & $\begin{array}{l}42 \\
10\end{array}$ & $\begin{array}{r}28 \\
115524\end{array}$ & $\begin{array}{r}1064714 \\
33439\end{array}$ & 25610 & 12456 & 310392 \\
\hline 1 & $\begin{array}{l}447 \\
447 \\
447\end{array}$ & $\begin{array}{r}3766 \\
37206\end{array}$ & 28 & 13621 & $\begin{array}{r}123790 \\
2811\end{array}$ & $\begin{array}{r}17 \\
2322\end{array}$ & 9070 & $\begin{array}{r}24650 \\
1\end{array}$ \\
\hline 3 & $\begin{array}{r}457 \\
457 \\
457 \\
\end{array}$ & $\begin{array}{r}1759 \\
29151 \\
\end{array}$ & 23 & 9620 & $\begin{array}{r}77640 \\
1186\end{array}$ & 1260 & 9108 & 14979 \\
\hline .1 & $\begin{array}{l}467 \\
467 \\
467\end{array}$ & $\begin{array}{r}0 \\
884 \\
\end{array}$ & 67 & 56 & $\begin{array}{r}2365 \\
6\end{array}$ & 13 & 0543 & 364 \\
\hline $\begin{array}{r}* 2 \\
+3\end{array}$ & $\begin{array}{r}477 \\
477 \\
477 \\
\end{array}$ & $\begin{array}{r}61 \\
12704 \\
\end{array}$ & 39 & 3403 & $\begin{array}{r}33225 \\
241\end{array}$ & 264 & 8984 & 5746 \\
\hline 4 & $\begin{array}{r}467 \\
487 \\
467 \\
\end{array}$ & $\begin{array}{r}3965 \\
69438\end{array}$ & 15 & 10366 & $\begin{array}{r}169941 \\
1574\end{array}$ & 2111 & $\begin{array}{r}9080 \\
1\end{array}$ & $\overline{2221 \overline{2}}$ \\
\hline 3 & $\begin{array}{r}497 \\
497 \\
497 \\
\end{array}$ & $\begin{array}{r}4499 \\
74224\end{array}$ & 218 & 11200 & $\begin{array}{r}204865 \\
3720\end{array}$ & $\begin{array}{r}13 \\
3322\end{array}$ & 9673 & $\begin{array}{r}3337 \\
1\end{array}$ \\
\hline$\because !$ & $\begin{array}{l}57 \\
57 \\
57 \\
\end{array}$ & $\begin{array}{r}3599 \\
72259\end{array}$ & 32 & 22477 & $\begin{array}{r}194506 \\
2597\end{array}$ & $\begin{array}{r}10 \\
3431\end{array}$ & 8725 & $\begin{array}{r}39738 \\
1\end{array}$ \\
\hline $\begin{array}{l}41 \\
: 2 \\
: 3\end{array}$ & $\begin{array}{l}517 \\
517 \\
517\end{array}$ & $\begin{array}{r}671 \\
16039\end{array}$ & $\begin{array}{r}15 \\
2\end{array}$ & 2455 & $\begin{array}{r}41935 \\
506\end{array}$ & 339 & 9170 & $\begin{array}{r}5196 \\
1\end{array}$ \\
\hline $\begin{array}{l}: 11 \\
01 \\
43\end{array}$ & $\begin{array}{l}527 \\
527 \\
527\end{array}$ & $\begin{array}{r}53 \overline{2} \\
11039 \\
\end{array}$ & 46 & 2804 & $\begin{array}{r}29517 \\
211\end{array}$ & $\begin{array}{r}12 \\
365\end{array}$ & 0470 & 5269 \\
\hline
\end{tabular}

(r) FILE: FILEIS DATA AI PORTLAND STATE UNTYERSITY VM/SP R4 03/27/07 8604.00 


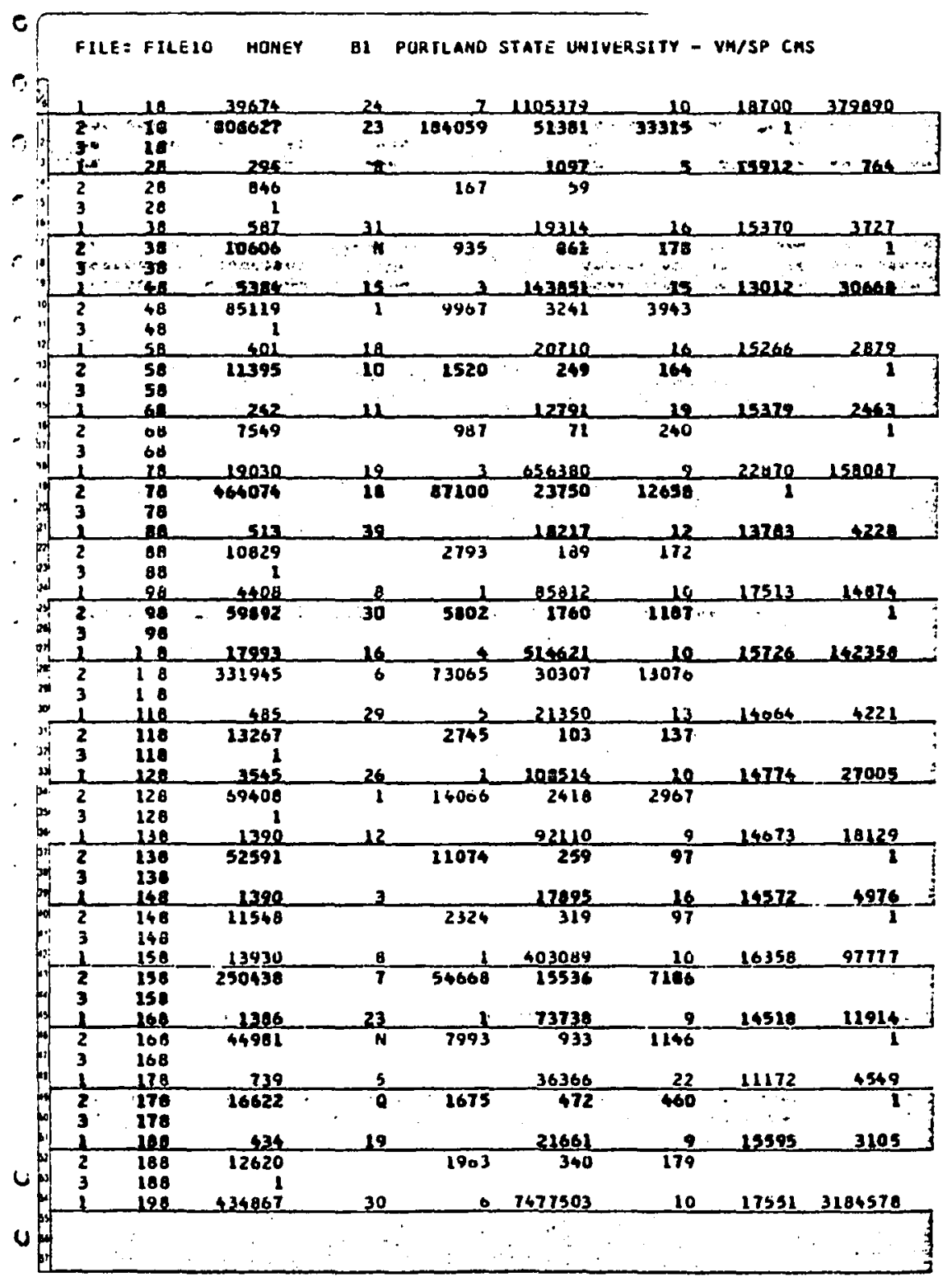

c. 


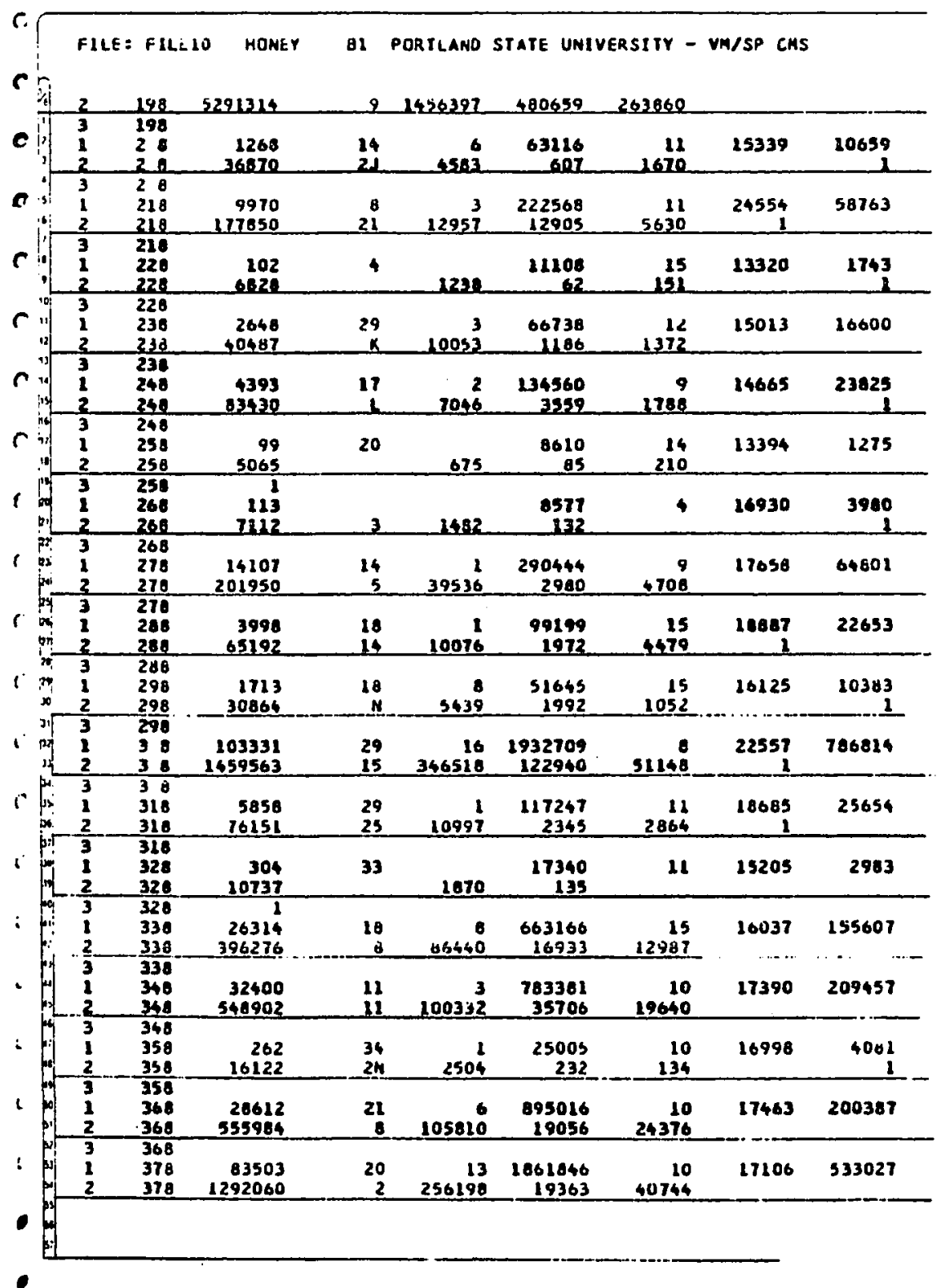


FILE: FILELO HUNEY HI PURILANO SIATE UNIVERSITY - VA/SP CMJ

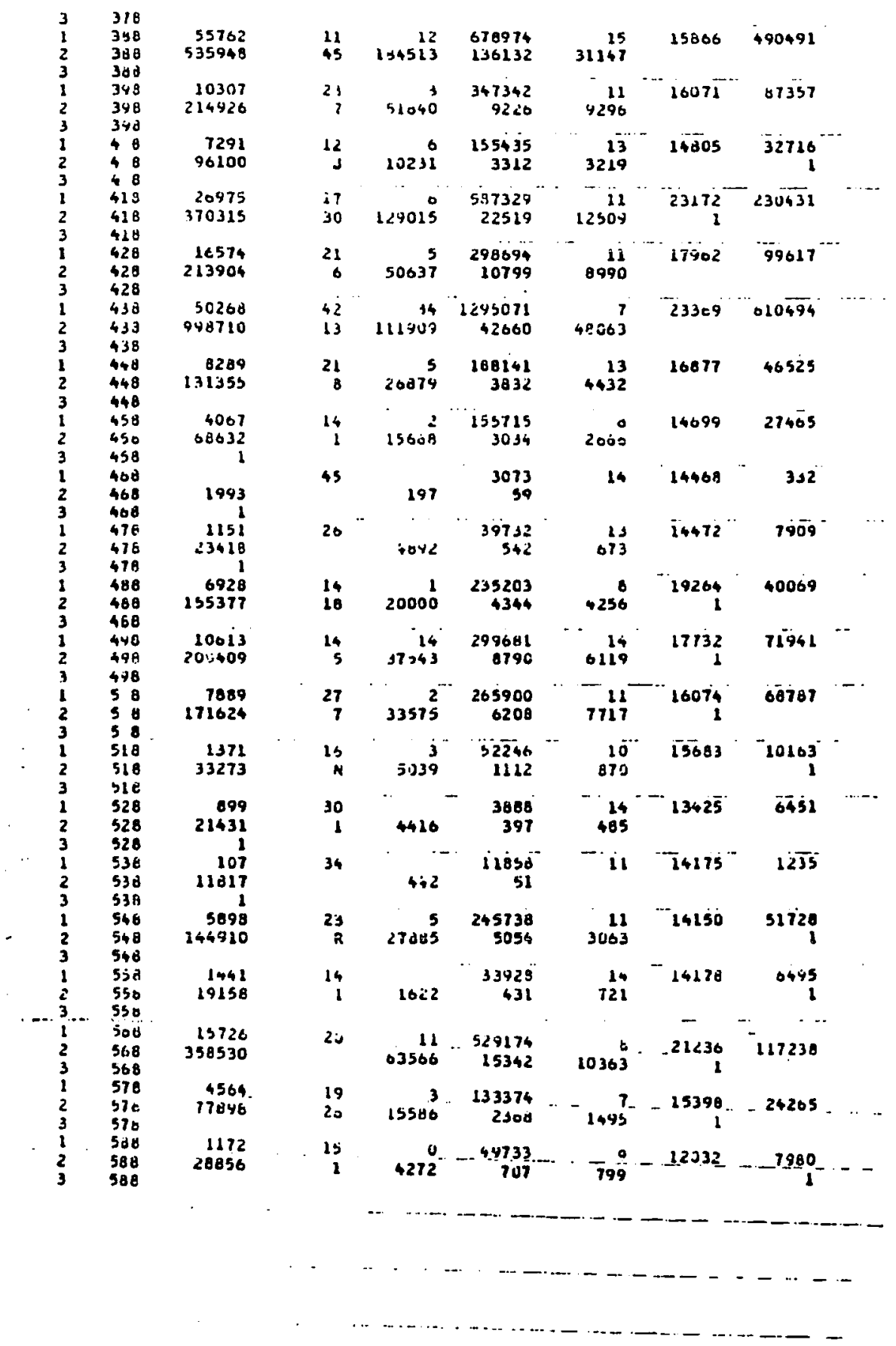

